\title{
Upper Cretaceous - Lower Tertiary decapod crustaceans from West Greenland
}

G E U S

Report file no.

22314

J. S. H. Collins and H. Wienberg Rasmussen
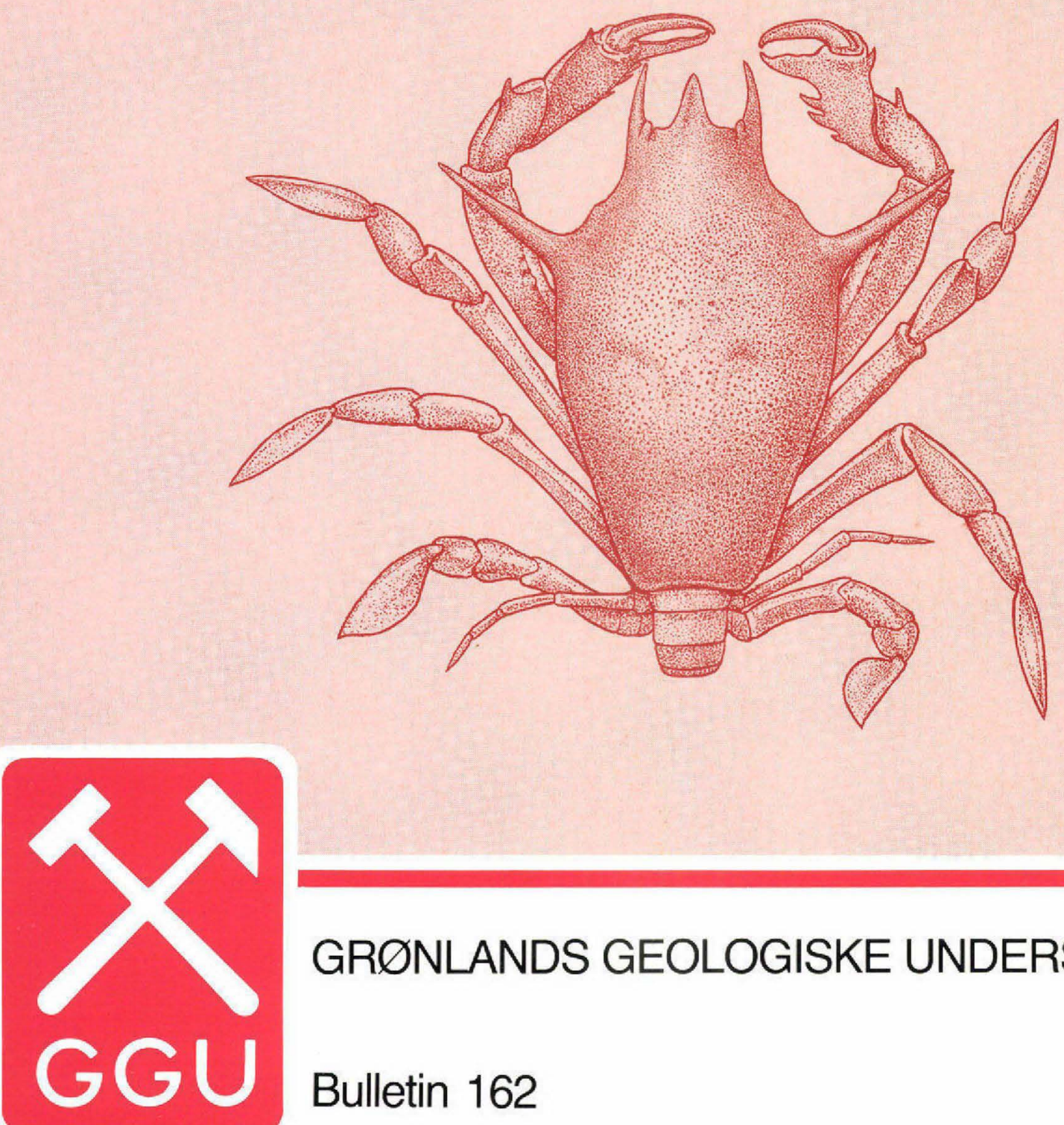

GRØNLANDS GEOLOGISKE UNDERSØGELSE

Bulletin 162 
GR ØNLANDS GEOLOGISKE UNDERSØGELSE

Bulletin 162

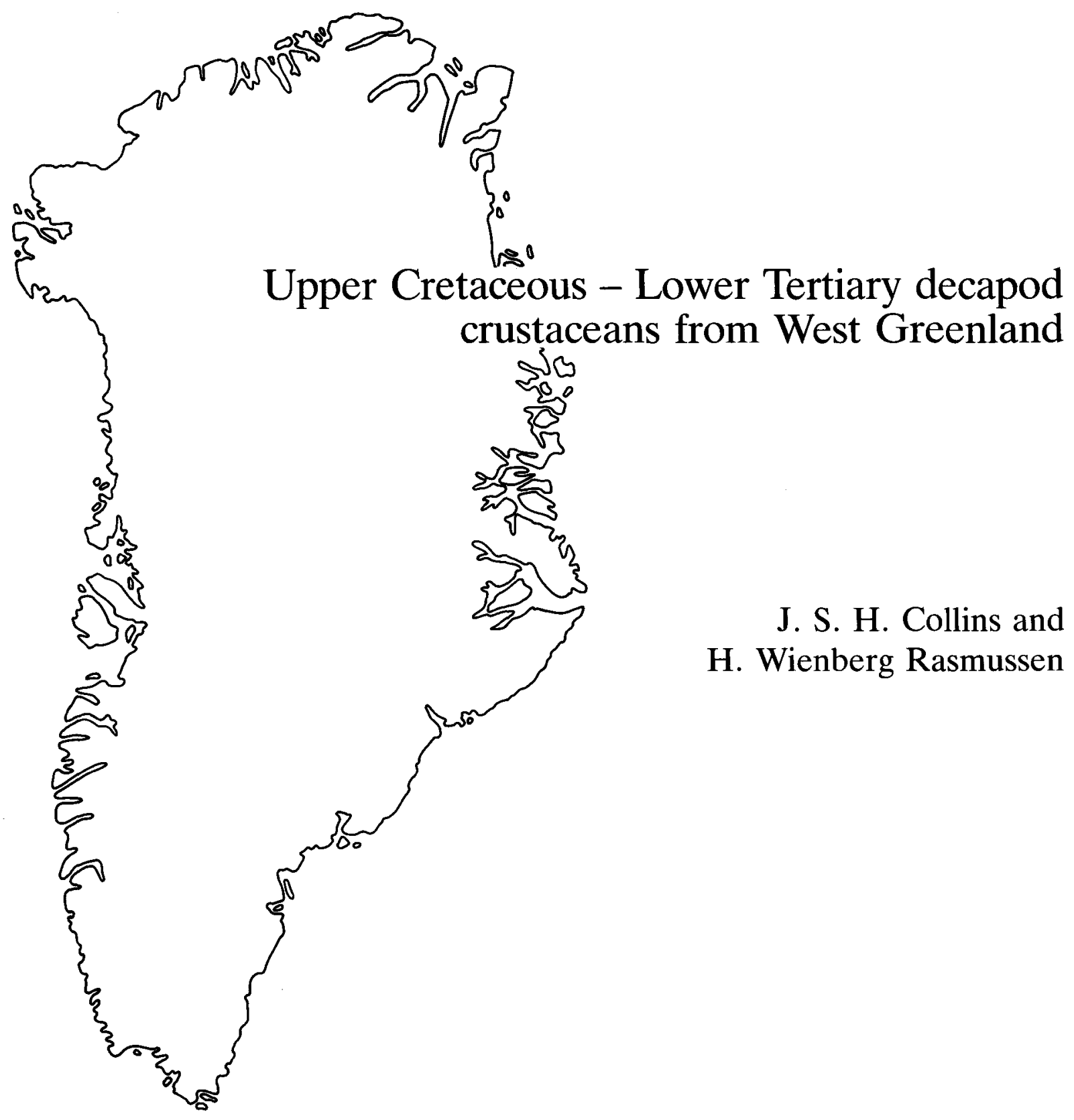




\section{Abstract}

Collins, J. S. H. \& Rasmussen, H. W. 1992: Upper Cretaceous - Lower Tertiary decapod crustaceans from West Greenland. Bull. Grønlands geol. Unders. 162, $46 \mathrm{pp}$.

Upper Cretaceous and Paleocene decapod crustaceans are described from Nûgssuaq, West Greenland; 14 genera, 3 of them new, contain 2 new macrurans, 13 new brachyurans and a galathaeid, referable to a previously described species. They form a mixed assemblage, although 7 of the brachyuran taxa and one of the macru- rans are of burrowing species. Homolopsis dispar Roberts 1962 is transferred to Eohomola gen. nov. and a new genus, Metahomola, is proposed.

Authors' addresses:

J. S. H. C., 8, Shaw's Cottages, Perry Rise, Forest Hill, London SE23 2QN, U.K.

H. W. R. (deceased), formerly at Geological Museum, Øster Voldgade 5-7, DK-1350 Copenhagen K, Denmark.

\section{Grønlands Geologiske Undersøgelse Ujarassiortut Kalaallit Nunaanni Misissuisoqarfiat Geological Survey of Greenland}

The Geological Survey of Greenland (GGU) is a research institute affiliated to the Mineral Resources Administration for Greenland (MRA) within the Danish Ministry of Energy. As with all other activities involving the non-living resources in Greenland, GGU's investigations are carried out within the framework of the policies decided jointly by the Greenland Home Rule Authority and the Danish State. 


\section{Contents}

Introduction.

Regional setting (by Gregers Dam)

Systematic palaeontology

Genus Mecochirus Germar, 1827

Mecochirus rostratus sp. nov.

Genus Linuparus White, 1847.

Linuparus (Podocrates) spinosus sp.

Genus Galathea Fabricius, 1793.

Galathea cf. G. strigifera Fischer-Benzon $1866 \ldots \ldots \quad 13$

Genus Dromiopsis Reuss, $1859 \ldots \ldots \ldots \ldots \ldots \ldots \ldots$

Dromiopsis granulata sp. nov. .............. 14

Genus Eohomola gen. nov. ................ 16

Eohomola adelphina sp. nov............... 16

Genus Hemioon Bell, 1863................... 19

Hemioon eysunesensis sp. nov. .............. 19

Genus Lyreidus de Haan, $1830 \ldots \ldots \ldots \ldots \ldots \ldots \ldots 23$

Lyreidus succedanus sp. nov................ 23

Lyreidus rosenkrantzi sp. nov............... 24
Lyreidus bispinulatus sp. nov. . . . . . . . . . . . 27

Genus Notopocorystes M'Coy, $1849 \ldots \ldots \ldots \ldots \ldots \ldots \quad 30$

Notopocorystes (Cretacoranina) paututensis sp. nov... 30

Genus Laeviranina Lörenthey \& Beurlen, 1929 ...... 31

Laeviranina borealis sp. nov. ................ 31

Genus Camarocarcinus Holland \& Cvancara, 1958.... 33

Camarocarcinus quinquetuberculatus sp. nov....... 33

Genus Cristella gen. nov. ................. 36

Cristella hastata sp. nov. ................ 36

Genus Xanthilites Bell, $1858 \ldots \ldots \ldots \ldots \ldots \ldots \ldots . \quad 38$

Xanthilites verrucoides sp. nov. ............. 38

Genus Pinnixa White, $1846 \ldots \ldots \ldots \ldots \ldots \ldots \ldots .40$

Pinnixa (Palaeopinnixa) nodosa sp. nov......... 40

Genus Costacopluma Collins \& Morris, 1975 ........ 41

Costacopluma binodosa sp. nov. ............ 42

Summary .......................... 44

Acknowledgements ...................... 45

References......................... 45 


\section{Dansk sammendrag}

Decapode crustaceaer fra øvre Kridt og Palæocæn i Nûgssuaq, Vestgrønland, beskrives. Fjorten slægter, 3 af dem nye, indeholder 2 nye macruraner, 13 nye brachyuraner og en galathaeid, som kan refereres til en tidligere beskrevet art. De udgør et blandet samfund med hensyn til livsmåde, men 7 af brachyuranerne og en af macruranerne hører til gravende arter. Homolopsis dispar Roberts 1962 overflyttes til Eohomola gen. nov. og én ny slægt, Metahomola, foreslås.

\section{Imaqarnersiuineq}

Decapode crustaceaer, uumasut qaleruallit Kalaallit Nunaata kitaani, Nuussuarmi Kridt-ip Palæocæn-illu nalaani, tassa ukiut 70 milliunit matuma siornatigut uumasimasut allaaserineqarput. Ilaqutariit 14-nit, taakkua akornanni pingasut aatsaat siumorneqarsimasut, immikkoortunik marlunnik macruraninik taaguutilinnik, 13-nik brachyuraninik taaguutilinnik ataatsimiillu galathaedinik taagutilimmik ilaqarput, siornatigut immik- koortunut allaaserineqarsimasunut assersuunneqarsinnaapput. Uumasut taakku inooriaasiat assigiinngitsorujussuuvoq, taakkuli ilaat uumasunut assaasartunut ilaallutik. Uumasut siumorneqarsimasut nutaat tunngavigalugit uumasut qaleruallit ilaat ilaqutaariinnut allanut nuunneqarpoq ilaqutariillu nutaat Metahomola-mik atsernissaat siunnersuutigineqarluni. 


\section{Introduction}

The Upper Cretaceous - Lower Tertiary decapod crustaceans from the Nûgssuaq peninsula, West Greenland (figs 1,24) described in the present paper, were collected by the late Professor A. Rosenkrantz, Copenhagen and co-workers in the coursę of 18 expeditions to West Greenland. The earliest expeditions, in 1938 and 1939, were supported by the Carlsberg Foundation, Copenhagen and Den Kongelige Grønlandske Handel (Royal Greenland Trading Company). Sixteen expeditions in the period 1946-1968 were under the auspices of Grønlands Geologiske Undersøgelse (GGU, Geologi- cal Survey of Greenland). A summary of the expeditions and their results was given by Rosenkrantz (1970).

Many workers have described fossils from the outstanding collections made by the Nûgssuaq expeditions (see summary by Rosenkrantz, 1970; Henderson et al., 1976; Kollmann \& Peel, 1983).

In 1978 the late Dr. H. Wienberg Rasmussen took up the study on the decapod crustaceans; a study which was not finished due to his untimely death in 1980 . The present paper is based on the unpublished material.

\section{Regional setting}

The Upper Cretaceous - Lower Tertiary rocks of West Greenland include both terrestrial and marine sediments as well as volcanic lavas and hyaloclastites.
The sediments occur on a series of islands and peninsulas between $69^{\circ}$ and $72^{\circ} \mathrm{N}$, from Disko in the south to Svartenhuk Halvø to the north. Together with outcrops

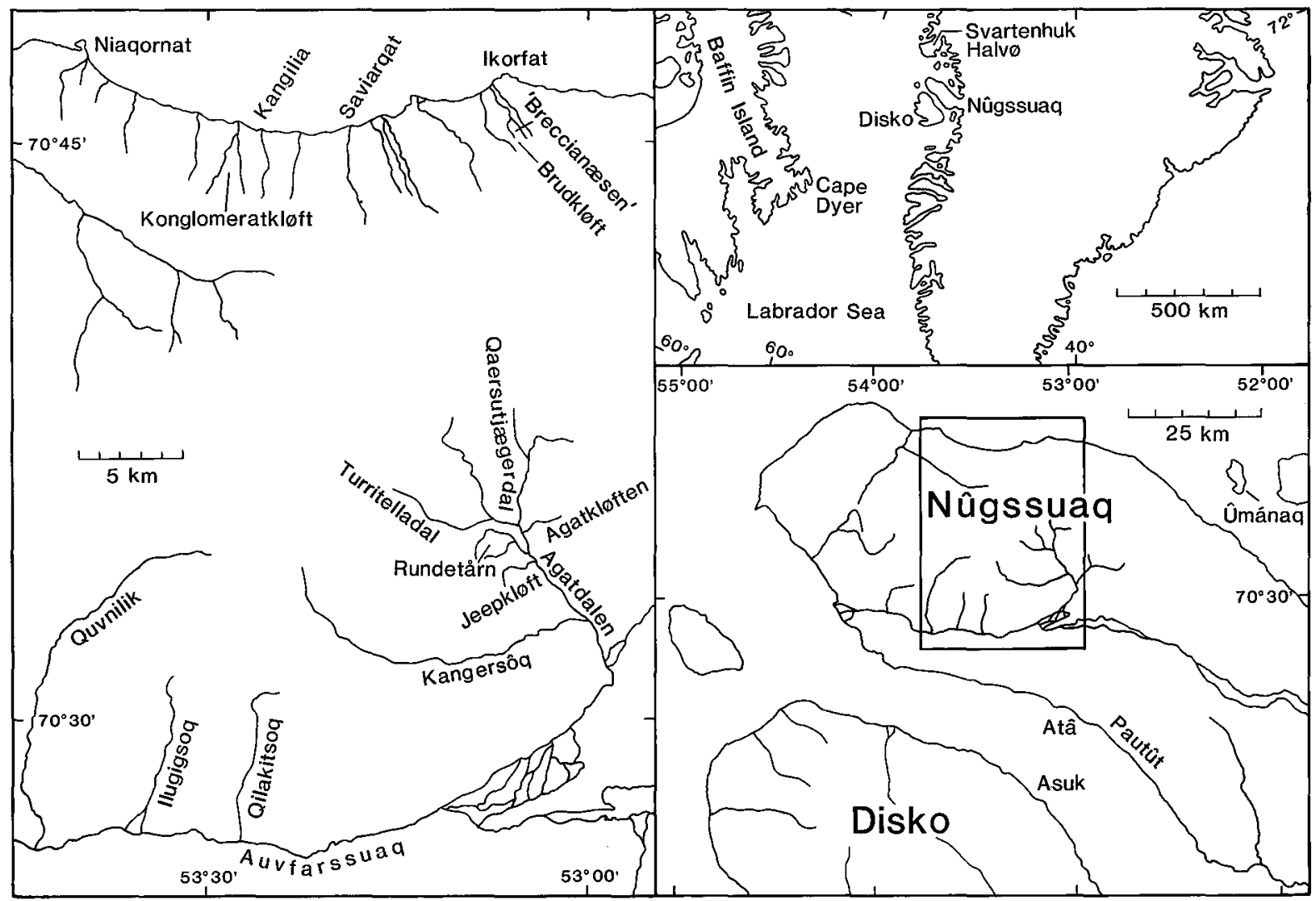

Fig. 1. Localities in Nûgssuaq, West Greenland. Agatdalen includes the 'Sonja lens', Rundetårn and Jeepkløft. Turritellakløft includes Scaphitesnæsen. 


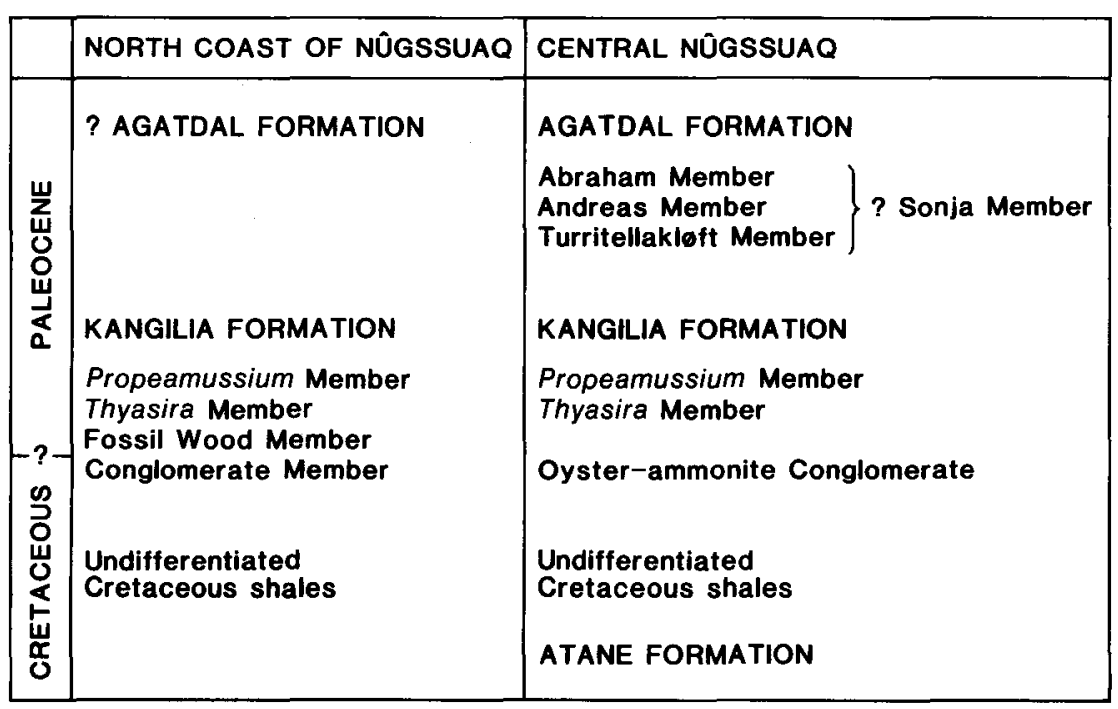

Fig. 2. Paleocene lithostratigraphy, Nûgssuaq, West Greenland. After Kollmann \& Peel (1983). at Cape Dyer on Baffin Island, they constitute the only onshore outcrops of sediments that were deposited in a series of rift basins that streches from the Labrador Sea to northern Baffin Bay. These basins formed along the continental margins of West Greenland and Labrador Baffin Island and are related to the opening of the Labrador Sea in late Mesozoic - early Cenozoic time.

The sedimentary succession in West Greenland is more than $2.5 \mathrm{~km}$ in thickness (Henderson et al., 1981). The sediments range in age from Early Cretaceous (Albian) to Early Tertiary (Paleocene) (see summary in Pulvertaft, 1987). The outcrops are bounded to the east by Precambrian basement rocks against which the Cretaceous sediments have a faulted contact (Pedersen \& Pulvertaft, 1992).

Cretaceous non-marine strata, outcropping in the eastern part of Disko and eastern Nûgssuaq, are referred to the Atane Formation. The non-marine sediments are fluvial in the southern and eastern parts of the area; westwards and north-westwards there is both a lateral transition in space and an upwards transition in time, through delta plain deposits with coal into delta front deposits with horizons containing typical shallow marine trace fossils and occasional bivalves and ammonites. In the south and east the non-marine sediments are of Albian-Cenomanian age, while to the west and north-west they are younger, in places possibly as young as early Campanian (Pedersen \& Pulvertaft, 1992).

Marine deposited, dark laminated shelf mudstones, sandstones and conglomerates of Late Cretaceous to Early Tertiary age are well exposed on the north coast of Nûgssuaq and on Svartenhuk Halvø, and are referred to as undifferentiated marine Cretaceous shales (lower part) and the Kangilia Formation (upper part) (Rosenkrantz, 1970). On the north coast of Nûgssuaq the Kan- gilia Formation comprises several members of conglomerates and shales (Fig. 2). The Kangilia Formation can be followed across Nûgssuaq and is reported from southern Nûgssuaq at Atâ and from cuesta-like basins at Asuk on Disko (Koch, 1959; Hansen, 1980). Erosional unconformities, coarse channelised conglomerates and sand-dominated units in this formation are reported from several localities (Rosenkrantz, 1970; Pulvertaft \& Chalmers, 1990; Christiansen et al., in press). In central Nûgssuaq, the Kangilia Formation is overlain unconformably by the shallow marine Agatdal Formation, comprising several members of sandstones and shales (Rosenkrantz, 1970; Fig. 2). Several beds in these members are rich in marine fossils, in particular a horizon in the Sonja Member, known as the Sonja lens.

The Cretaceous-Paleocene marine strata in the central and northern part of Nugssuala have been biostratigraphically dated, mainly on the basis of ammonites, dinoflagellates and foraminifera (Birkelund, 1965; H. J. Hansen, 1970; Croxton, 1976; Ehman et al., 1976; J. M. Hansen, 1980) and to a lesser extent by inoceramid bivalves (see Rosenkrantz \& Pulvertaft, 1969, table 1). Dating of the non-marine strata is less exact, but some limits can be placed on the ages of these by correlation between the marine and non-marine strata and by fossil plants and pollen.

Gregers Dam

\section{Note on localities}

The most important outcrops are shown in Fig. 1. Upper Cretaceous outcrops were described by Birkelund (1965) and Lower Tertiary outcrops by Hansen (1970) and Floris (1972) (see also Rosenkrantz, 197O; Henderson et al., 1976). 


\section{Systematic palaeontology}

Infraorder Palinura Latreille, 1802

Superfamily Glypheoidea Winckler, 1883

Family Mecochiridae Van Straelen, 1925

\section{Genus Mecochirus Germar, 1827}

Type species. Mecochirus longimanatus (von Schlotheim, 1820) by subsequent designation of H. Woods, 1927.

Range. Middle Triassic to Upper Cretaceous.

\section{Mecochirus rostratus sp. nov.} Figs 3A-C, 4A-B

Derivation of name. With reference to the rostrum which is larger than in any other species of this genus.

Diagnosis. - A Mecochirus with very long, pointed rostrum with dorsolateral spines. Carapace thick, strongly calcified and distinctly sculptured with more or less forwardly directed spines on anterior and dorsal areas. The postorbital ridge is weakly developed. The cardiac region is divided by a depression into anterior and posterior parts. The postcervical and branchiocardiac furrows run closely parallel from a nodose elevation near the dorso-posterior margin. The antennal exopod has a large scaphocerite with a long distal and small lateral spine. All pereiopods long and slender with a long, slender, curved dactylus; no chelae and not typically subchelate. First pereiopod with very long propodus.

Material. 2170 cephalothoraces from two horizons. Holotype MGUH 21.580 and 1862 additional specimens are from Maastrichtian concretions found as boulders in the Late Danian 'oyster-ammonite conglomerate' at Agatkløft, 405-410 m; 299 are from the same conglomerate at western side of Agatdalen, $510-530 \mathrm{~m}$; four from above the river plain near Agatkløften; one from the Kangersôq river bed; one from a profile on the south side of Turritellakløft; one from the Maastrichtian of Ikorfat, 980-985 m; and one from the Upper Campanian of Brudkløft at Ikorfat, $550-625 \mathrm{~m}$ on the north coast of Nûgssuaq (Fig. 3).

All specimens are found in dark grey to black calcareous concretions. Most of them are fairly complete with carapace, abdomen and legs, but the very long first pair of pereiopods are incomplete in almost all specimens, only the proximal part being included in the concretions. It appears that all specimens are broken along the dorsal midline and the rostrum is broken off, although the parts are generally not much disturbed - as such, they may well represent exuviae.

The carapace was exposed and measured from frontal to posterior margins (rostrum excluded) in 687 specimens and showed a size range from 9.3 to $32.9 \mathrm{~mm}$. The size-frequency distribution shows a simple symmetrical bell-shaped form with a mean of $22.1 \mathrm{~mm}$ and standard deviation $3.4 \mathrm{~mm}$. There is no indication of separate size groups which could be age classes or successive exuviae. If most specimens are exuviae, the ecdyses are not bound to distinctly separate common size groups within the population.

Description. Carapace subcylindrical, length excluding rostrum about twice the dorso-ventral height, or slightly less, with the greatest height close behind mid-carapace length. Neither the carapace nor rostrum undergoes any allometric change of form during growth.

The dorsal midline is almost straight, entrenched at the cervical furrow and rather less between the anterior and posterior parts of the cardiac region. Anteriorly the ventral margin curves gradually upwards towards the front, but has a slightly bulging pterygostomial area. The posterior margin has a prominent, finely granulated ridge, bounded behind by a smooth depressed rim, projecting backwards in a lobe near the top of the branchial region and the dorsal part of the margin forms an embayment along the cardiac region. The slender rostrum equals about half of the carapace length measured between the frontal and posterior margins. As preserved, it is in all instances fractured at its base from the carapace, although generally not much disturbed. It is directed straight forward, although slightly undulant and gradually tapers distally to a blunt point; deeply Vshaped in section, it is sulcate above, ridged below, the width and depth of the sulcus increasing proximally until on reaching the carapace it flattens and is divided by a low median ridge starting just behind the frontal margin. The dorso-lateral edges of the rostrum are provided with sharp forwardly and outwardly projecting spines that continue onto the carapace as carinae on either side of the dorsal midline almost to the cervical furrow where they curve towards the midline and, becoming obsolete, delimit a narrow lanceolate dorsal area which is divided by a low, narrow median ridge lined with small spines and granules. The total number of spines on either side of the rostrum varies from six to 


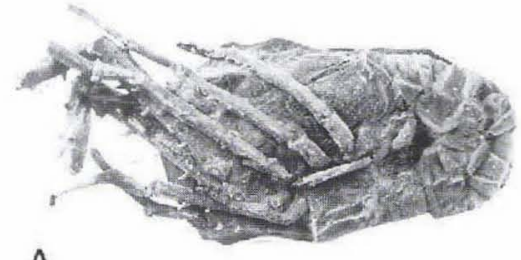

A

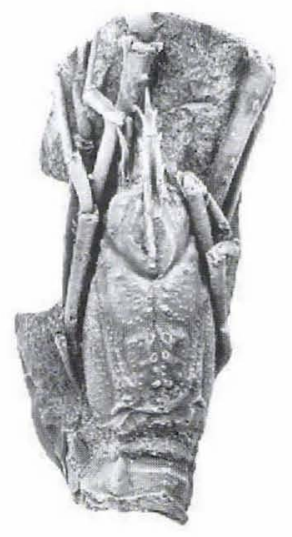

B
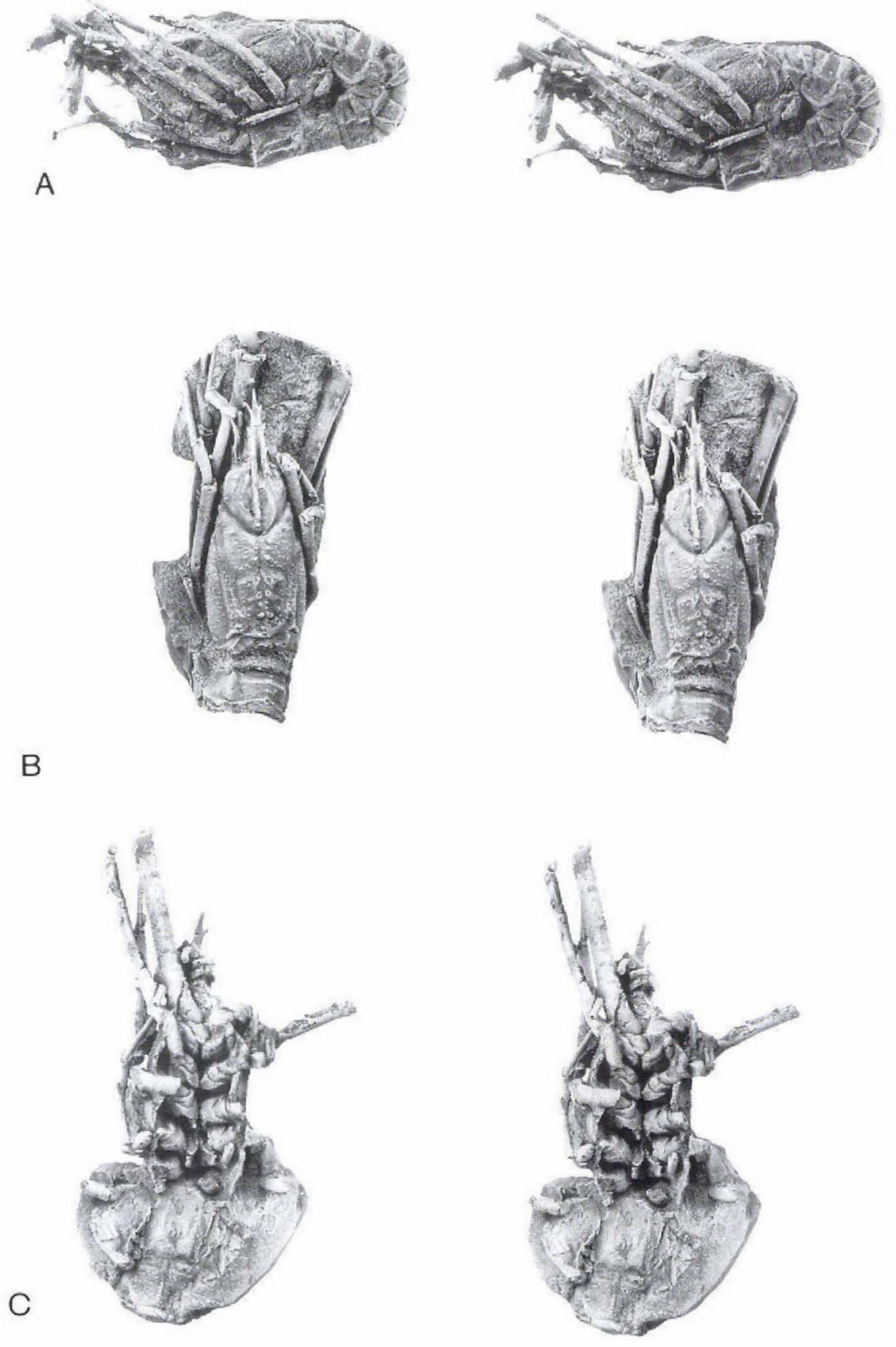

Fig. 3. Mecochirus rostratus sp. nov, from the

Maastrichtian at Agatkløft, $\times 1$. A: holotype, MGUH 21.580, side view; B: paratype, MGUH 21.581, dorsal view; C: paratype, MGUH 21.582, ventral view. 
Fig. 4. Mecochirus rostratus sp. nov. from the Maastrichtian at Agatdal, $\times$ 1. A: paratype, MGUH 21.583 , side view showing details of the rostrum; B: paratype, MGUH 21.584. ventral view showing details of maxillipeds.
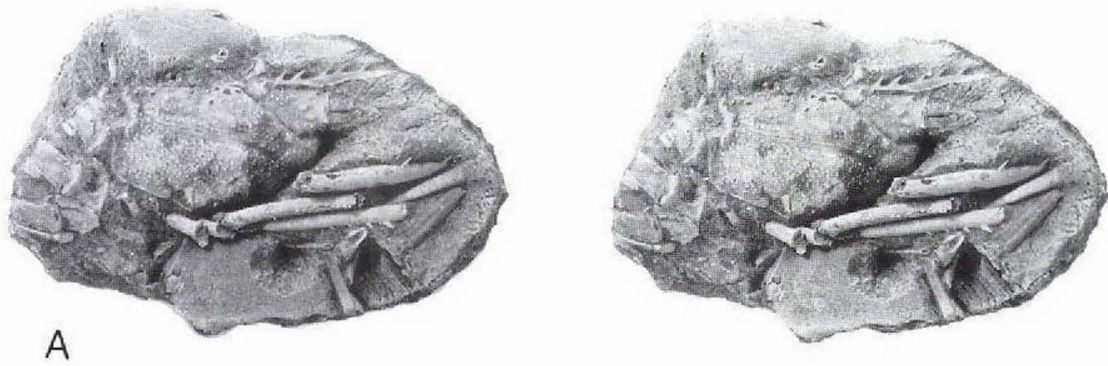

$\mathrm{B}$

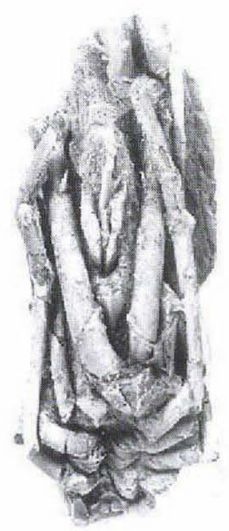

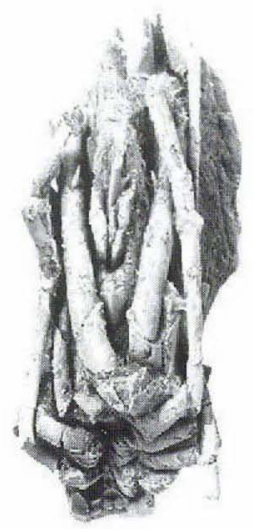

eight, of which three occupy the projecting part; they are normally arranged opposite one another although alternating exceptions occur. The ventrolateral parts of the rostrum, are almost smooth, or have low tubercles at midlength and a short oblique ridge or row of tubercles may run from the sides into the frontal margin. The orbital margin is almost straight and the upper orbital spine immediately under the rostrum is followed by two or three small spines forming an inconspicuous ridge running back onto the carapace at a diverging angle from the rostral carina; the suborbital spine set immediately below has a smaller spine behind.

The cervical furrow forms a deep, rather broad depression with a steep posterior wall sloping very obliquely downwards and forwards, to unite with the antennal furrow which is distinct and reaches the front just below the antennal spine. The postcervical and branchiocardiac furrows are very shallow and oblique; running forward almost parallel from in front of the elevation bounding the posterior margin, they unite with the hepatic furrow, the area enclosed by the furrows is depressed and a faint groove passes upward from the postcervical furrow to the dorsal margin.

There is a row of three large, forwardly directed spines decreasing in size and distance apart posteriorly on the anterior part of the cardiac region, with additional smaller spines and granules scattered over the surface, and often there are faint irregular wrinkles which, radiating from the dorsal midline, follow the posterior margin. The branchial region is covered with small more closely crowded granules, irregular in form and size, but generally in the nature of clusters of very small granules between larger irregular ones or granulated elevations. Fine densely crowded granules cover the slightly tumid pterygostomian area and there is a tendency for a single row of coarse granules to border the antennal furrow.

In some specimens where the branchiostegite has been removed and the branchial epimeres are seen as a fan of four folds forming the inner wall of the branchial chamber. The anterior fold is oblique and follows the cervical furrow, while the steep posterior fold follows the posterior margin.

The eyestalk is preserved and identified in only a few specimens. The antennule has a large, almost pyriform but flattened basal segment with a globular swelling on the presumed ventral side of the broad proximal part containing a small cavity - apparently the statocyst opening on the flat dorsal side. There is a rounded ridge and a row of well separated pits for the attachment of 
setae along the inner and outer edges, and a distal spine in continuation of the inner edge. The two succeeding elements are apparently smaller and subcylindrical; the flagellae have not been seen.

The antenna, and especially the very characteristic large, bifurcate and pointed scaphocerite, is well preserved in many specimens. The coxa is rather short and wedge-shaped with a large ventral tubercle for the antennal gland. The large basis is triangular in section, the outer side forming a rounded ridge ending in a spine; the segment is a little wedge-shaped with the ventral side projecting. The first segment of the endopodite is strongly wedge-shaped and attached along the inner edge of the basis. The second segment is long, subcylindrical, the third is similar, but shorter. Part of a long flagellum is seen in a few specimens; the first segment of the exopodite is a small scale, seldom observed, but the second, or scaphocerite, is large and forms a very long slender, slightly curved, forwardly directed spine with a shorter lateral spine near the base. The spine is triangular in section with a row of pores for setae along the sharp convex edge.

The mandibles are retained more or less in situ in several specimens where the anterior part of the carapace is broken or was removed during preparation, they form club-shaped elements with a strongly calcified tumid outer surface. There is a hemispherical lower end with the gnathobase, separated from a pointed shaft by an oblique furrow where the palp was attached. The ischiognath of the rather large maxillipeds is stout, triangular in section with sharp margins, the inner of which is dentate and there are numerous setae pores along the ventral edge. The merognath is large, broad, elliptical and much flattened with one to four spines along the ventral edge. The carpus is conical, subtriangular in section and curved, the proximal end almost perpendicular to the rest of the segment. The propodus is straight, subcylindrical to subtriangular with a flattened inner side. The dactylus is smaller and rounded distally.

All the pereiopods have slender terminal segments, or the first two pairs may be considered slightly subchelate. The first pair is longer and has a larger diameter than the succeeding pairs; the length is about three times that of the carapace (rostrum excluded) and the distal end is generally not preserved within the concretion containing the rest of the animal, the diameter is about twice that of the other limbs. The coxa is stout with an almost flat, rhomboidal ventral surface divided by a narrow furrow near the distal margin. The fused basis and ischium has a distinct suture along which the specimens are often broken; the segment is rather short, subcylindrical and wedge-shaped, longer along the in- ner side with a distinct distal inner spine, the surface is granulated. The merus is long, about $0.7-0.85$ of carapace length and about 3-4 $\mathrm{mm}$ in diameter, a little compressed and elliptical in section; spines along the lower edge may form a single row or alternate in a double row of 4-10, there are a few on the upper edge decreasing in size distally and a few granules are scattered mostly on the outer side. The carpus length is about half that of the merus, in section rounded to subquadrate with four blunted edges, each with one or two spines, its surface is granulated. The propodus is very long, generally a little longer than the merus, but the distal end is seldom preserved, it is similar in diameter and section to preceding segments, with a granulated surface and a row of spines along the upper, lower and outer edges. A ventral spine distally does not reach beyond the distal end of the segment nor does it constitute an opposing spine or fixed finger. Thus the first pereiopod is not typically subchelate. The long dactylus is slender, compressed and curved with a median row of closely placed setae pits on the outer side; it is as long, or a little longer than the carpus and between a third to a half the length of the propodus.

The second pereiopod is a little smaller and more slender than the first, there is a scattered surface granulation; the large subtriangular coxa has a flattened ventral face subdivided by a curved transverse furrow. The short basis is wedge-shaped. The ischium is subcylindrical and obliquely terminated. The merus is slender, its length about $0.8-0.9$ of that of the first pereiopod and in diameter a little more than half, it is elliptical in section with 4-5 spines equally spaced along the ventral edge. The carpus is about one third of meral length or less, strongly curved proximally, elliptical in section with the greater diameter distally where the joint with the propodus is almost perpendicular, there is a spine at the upper and lower angles of the joint. The propodus is almost twice the length of the carpus, or half that of the merus, distinctly flattened with the greater diameter equal to that of the merus and twice the small diameter; there is a distal ventral spine and a row of closely placed setae pits on the inner side of the rounded dorsal and narrow ventral edges. The dactylus is somewhat shorter than the propodus of the first pereiopod.

In contrast the coxa of the third pereiopod has a rounded, less angular surface, as does the wedgeshaped basis; the ischium is a little less oblique at the distal joint; the merus is a little shorter and has a single ventral row of 4 or 5 equally spaced spines increasing in size distally contrary to the granules which decrease in size distally; the propodus is almost smooth and the dactylus lacks setae pits. 
The fourth pereiopod is closely similar to the third, but the merus is slightly shorter and has a row of 3-5 closely spaced spines along the distal part of the ventral side, the median ones the largest.

The fifth pereiopod is somewhat shorter and much more slender, diameter of merus $c$. $0.5-0.7 \mathrm{~mm}$, and propodus less. The surface is smooth or maybe slightly granulated in proximal segments; there are no spines except for distal ones on the carpus and propodus. The dactylus is about half the length of the propodus.

The abdomen is long and subcylindrical, each somite has the tergum transversely divided by two furrows into a smooth anterior area, a more or less elevated median area and a triangular posterior area; a low granulated ridge flanked posteriorly by an articulating boss separates each tergum from the pleura. The first somite has the anterior furrow curved backwards along the projecting lateral (pleural) ridges and uniting with a chevronshaped posterior furrow; on each side of the lateral edge is a slight incision. There are granules along the bilobate anterior ridge of the elevated median area and a spine on each side of the midline; less prominent granules and a pair of smaller spines occur along the leading edge of the posterior area. The second somite has a smooth frontal area before a prominent transverse furrow bounded behind by a ridge with a pair of small dorsal spines; a second furrow and ridge curve back to the articulating boss. The third and fourth somites are essentially similar, but the fourth has in addition to the median pair of dorsal spines a few median - or a double row - of granules or small spines along the midline, and this arrangement is emphasised on the fifth somite in which the anterior transverse ridge becomes obscure and the median area is longer. The sixth somite has the anterior areas small and depressed, the median area is long with scattered granules and the anterior ridge is replaced by a mid-dorsal row of tubercles.

The elongate pleura of the first somite are separated not so much by a ridge as an entrenchment from the tergum. The pentagonal second pleura are the largest and partially overlap the margins of the first and third pleura; the third-fifth become rounded in outline, while the sixth is much narrower and foreshortened by an embayment for the uropods. The second-fifth pleura have a median lingulate area bounded by a depression which is somewhat wider and shallower on the anterior side, there is a strong, granular marginal rim and a few scattered granules on the hinder part of the median area and posterior margin, leaving the depression relatively smooth. On the sixth pleura a ridge takes the place of the marginal granules.

The large rectangular telson has straight lateral margins and a convex posterior margin; a node on either side of the dorsal midline is bounded by a furrow followed by a granulated ridge, pendant from this ridge lower, much shorter ridges are united medially by granules then become almost obsolete as they curve towards the posterior margin. Laterally, a much stronger ridge extends from the middle of the curved ridge to the posterior angle which is often armed with a small spine. With the exception of the two ridges the surface has scattered granules on the posterior area and there are closely spaced feeble ridges radiating to the posterior margin. The uropodites are attached to the pleural embayment of the sixth somite by short, rounded undivided protopodites. The endopodite and exopodites are broad, leaf-like, slightly oblique-elliptical in outline. The endopodite is strengthened by a single median rib, the exopodite has a median pair of blunt ribs and the inner one continues across the diaresis, which forms a dentate furrow, to the distal margin.

Discussion. Mecochirus rostratus differs from most species in this genus in having a long pointed rostrum with lateral spines, relatively weak orbital and antennal ridges and a depression between the anterior and posterior parts of the cardiac region. The postcervical and branchiocardiac furrows run back at a very low angle towards the posterior margin, apparently not meeting the dorsal line. The pereiopods are not distinctly subchelate, although in having a small distal spine on the propodus opposing the long dactylus, the second pair only may be described as slightly subchelate. The flattened propodus of the second pereiopod is 3-4 times as long as wide and the propodus length of the first pereiopod is less than the carapace length. Only the Upper Jurassic M. marwicki Glaessner, 1960 from New Zealand has a similar rostrum, but this species differs in the ornament of the carapace, the almost smooth abdomen and the stout first pair of pereiopods.

A single somewhat fragmentary cephalothorax of $M$. crofti (Ball, 1960) from James Ross Island, Antarctica, the only other known Campanian species, is readily distinguished from $M$. rostratus by the arrangement of its major furrows. The two species represent the youngest known members of the genus. Meyeria? harveyi, established by Woodward (1900) from unspecified Upper Cretaceous of Hornby Island, British Columbia, Canada, is presumably a Mecochirus, but the species is considered a nomen nudum by Förster (1971). According to Whiteaves (1903) it comes from the Nanaimo group, equivalent to the Upper Chalk of England and the Senonian of France.

Ecology. It was demonstrated by Förster (1971, p. 412) that out of 32 species of Mecochirus for which informa- 
tion regarding the sediment was available, 25 are found in clay or mud either dark shales or clayey concretions. Förster considered most of these specimens to be dead individuals rather than exuviae since pyrite along fissures, openings and ventral surface of the fossils indicates decay of organic tissue. Also, the fossils are generally preserved with the pereiopods directed forwards not irregularly in all directions and the abdomen is bent forward below the cephalothorax. This was taken by Förster as indicative of preservation after death, although there is little information regarding posture in dead bodies or exuviae among Recent macrurans for comparison.

The thin carapace was taken as an indication of a burrowing habit, although the very long first pereiopods were considered to preclude life in a burrow. It is generally considered that most macruran decapods may excavate and take shelter in simple, short burrows, even if they show no morphological adaptation for a burrowing life, as was demonstrated by Rice \& Chapman (1971) for Recent Nephrops. Bromley \& Asgaard (1972) referred complicated systems of thalassinoid burrows from the Lower Jurassic of East Greenland to the activity of Glyphaea rosenkrantzi Van Straelen, 1929, which appears quite unfit for life in narrow 'tubes', considering the rigidly calcified skeleton, the thorny ornament and the long pereiopods.

The specimens of Mecochirus from Nûgssuaq are generally preserved without pyrite and there is no indication whether they were dead bodies or exuviae, but the antennal scale, pereiopods and abdomen are generally preserved in almost natural position suggestive of dead individuals. There is no indication whether they were burrowers or not, but they are more strongly calcified and have larger spines on the carapace and rostrum than other species of Mecochirus, and the first pair of pereiopods, although not extreme for the genus, seem long enough to exclude a life in burrows.

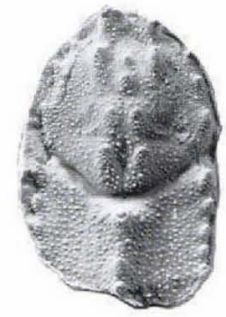

Fig. 5. Linuparus (Podocrates) spinosus sp. nov. from the Upper Campanian of Ikorfat. Holotype, MGUH 21.585, dorsal view of the carapace, $\times 1$.
Superfamily Palinuroidea Latreille, 1802

Family Palinuridae Latreille, 1802

\section{Genus Linuparus White, 1847 Subgenus Podocrates Geinitz, 1849}

Type species. Podocrates duelmense Geinitz, 1849, by monotypy.

\section{Linuparus (Podocrates) spinosus sp. nov.}

Fig. 5

Derivation of name. With reference to the stout spines on the carapace.

Diagnosis. A Podocrates with large, stout supraorbital and postorbital spines followed by two median spines and two pairs of spines close to the midline: there are three equidistant spines on each suborbital ridge. On the branchial region the median ridge is strongly spinose and the marginal spines decrease in size and distance apart posteriorly.

Material. The holotype (MGUH 21.585) and only known specimen is in a small calcareous concretion from the dark bituminous shales, Upper Campanian, of Brudkløft at Ikorfat, $550 \mathrm{~m}$ above sea-level on the north coast of Nûgssuaq.

Description. The specimen shows the dorsal surface of the carapace between the supraorbital ridges, and part of the branchial region. The portion of the carapace anterior to the postcervical furrow is weakly convex in side view. Large supraorbital spines are united by a low semicircular ridge and each spine is continued back as a slightly divergent ridge with a concave space between. Behind the supraorbital spines the stout postorbital spines continue the diverging line and between them is a median spine with a larger one immediately behind. Then follow two pairs of bluntly pointed, ridged spines; the first pair set very close to the midline, curve backwards and outwards and gradually taper to obscurity in a shallow depression; the hinder pair, slightly wider apart anteriorly, are longer and curve towards the midline posteriorly, terminating at the postcervical furrow where they are separated from one another by a sulcus. Together the spines enclose a narrow fusiform area. The anterior margin to either side of the supraorbital spines is missing. External to the base of the supraorbital 
spines a rounded, barely elevated suborbital ridge bearing three equidistant spines curves to the postcervical notch. The lateral wall of the ridge is steep, and somewhat concave. The postcervical furrow is wide and deep with the posterior wall sloping steeply back throughout its length; it is broadly curved at the midline and obtusely $\mathrm{V}$-shaped to the suborbital ridge. The carapace behind the postcervical furrow is incomplete. The part preserved has a median carina with three spines reducing in size posteriorly; the distance between the first and second spines is about equal to the basal length of the second and third spines together. On either side of the foremost of these two spines is an enlarged granule. There are five spines reducing in size and distance apart on the lateral margins and the surface between the lateral margins and median ridge is regularly concave.

Apart from the bases of the postcervical furrow and the groove between the hindmost of the median paired spines the entire surface is covered with rounded granules of several diameters generally well separated, but crowding the spines and ridges; on the branchial region they tend to form longitudinal rows.

Discussion. Linuparus (P.) spinosus is similar to $L$. (P.) africanus Glaessner, 1932, L. (P.) schluteri (Tribolet, 1874), L. (P.) grimmeri Stenzel, 1945, L. (P.) watkinsi Stenzel, 1945, and L. (P.) eocenicus Woods, 1925, in its tuberculate surface and in the general pattern of spines, but in $L$. (P.) spinosus the spines are much stouter and the two pairs of spines between the suborbital ridges, and postcervical furrow are closer to the midline. Furthermore it differs from $L$. (P.) africanus and $L$. (P.) grimmeri in having two median spines and a stronger ornament on the anterior part of the carapace; from $L$. (P.) schluteri, L. (P.) grimmeri and L. (P.) watkinsi it differs in having only three spines along the suborbital ridge. The supraorbital spines of $L$. (P.) eocenicus are united by a ridge and the suborbital ridge has 3-5 spines, there is, however, only a single elongate median tubercle set between the postorbital spines.
Infraorder Anomura H. Milne-Edwards, 1832

Superfamily Galatheoidea Samouelle, 1819

Family Galatheidae Samouelle, 1819

Subfamily Galatheinae Samouelle, 1819

\section{Genus Galathea Fabricius, 1793}

Type species. Cancer strigosus Linné, 1761 by subsequent designation Latreille, 1810 [ICZN opinion 434].

Range. Lower Cretaceous to Recent.

\section{Galathea cf. G. strigifera Fischer-Benzon 1866}

Fig. 6

1866 Galathea strigifera Fischer-Benzon, p. 28, pl. 5, figs $4-6$.

1900 Galathea strigifera Fischer-Benzon; Segerberg, p. 352 , pl. 7 , figs 1,2 ?

1929 Galathea strigifera Fischer-Benzon; Glaessner, p. 173 (see also for other synonymies).

Range. Paleocene, Danian.

Material. A dorsal fragment of a carapace (MGUH 21.586) from the slightly consolidated sand of the 'Sonja lens' in the Agatdal Formation in Agatkløften, Nûgssuaq.

Remarks. The carapace fragment is $6.0 \mathrm{~mm}$ in length and $5.0 \mathrm{~mm}$ in width; the rostrum and lateral margins are not preserved. From close behind the anterior margin to a little behind the cervical furrow the surface shows a pattern of undulating transverse ridges similar to the Middle Danian $G$. strigifera from Fakse, Denmark. The sharp edges of the transverse ridges show a fine and delicate crenulation and a row of very small setae pits on the steep anterior side. The posterior side of each ridge is smooth and flat, gently sloping. No spines are preserved on the dorsal surface and it is uncertain whether or not the frontal area was granulated.
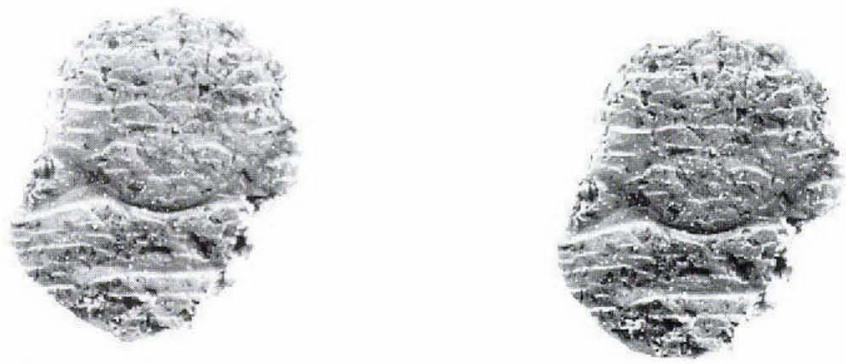

A
Fig. 6. Galathea cf. G. strigifera Fischer-Benzon from the Middle Paleocene at Agatkløft, 'Sonja lens', MGUH 21.586, dorsal view of carapace, $\times 1$. 
Among fossil Galatheinae described the present specimen comes very close to $G$. strigifera, but the variation within species of Galathea is considerable and a safe determination of small fragments is not possible.

Infraorder Brachyura Latreille, 1803

Section Podotremata Guinot, 1977

Sub-section Dromiacea de Haan, 1833

Superfamily Dromioidea de Haan, 1833

Family Dynomenidae Ortmann, 1892

\section{Genus Dromiopsis Reuss, 1859}

Type species. Brachyurites rugosus von Schlotheim, 1820, by subsequent designation Beurlen, 1928.

Range. Upper Cretaceous to Paleocene.

\section{Dromiopsis granulata sp. nov.} Figs 7A-D

Derivation of name. With reference to the granulated surface of the median gastric region.

Diagnosis. - A Dromiopsis with rounded pentagonal outline; lateral edge sharp, forming a ridge with small, well separated spines. Cervical and branchiocardiac furrows distinct, the branchiocardiac furrows stopping at the conspicuously delimited cardiac region. Dorsal surface almost smooth with fine pores, and close granulation on the meso-urogastric region. The gastro-hepatic region is undifferentiated.

Material. Holotype, a carapace and associated chela (MGUH 21.587). In an Upper Cretaceous, Maastrichtian, concretion from the 'Oyster-ammonite conglomerate' on the west side of Agatdalen, $530 \mathrm{~m}$ above sea level. Paratype, a longitudinally compacted carapace (MGUH 21.588). 'Oyster-ammonite conglomerate', locality III at alt. $510 \mathrm{~m}$ on west side of Agatdalen.

Description. The carapace is rounded sub-pentagonal in outline, a little longer than wide, with the greatest width just anterior to the cervical furrow, regularly tumid transversely, in longitudinal section it is convex with the highest point more or less coincident with the greatest width. The front is damaged, but has most of one side preserved to indicate a triangular form. The orbitofrontal width occupies three fourths of the carapace width and the large, broadly elliptical orbits form an angle of about $85^{\circ}$ to the midline. The upper orbital margin is raised with no indication of an outer orbital spine; the lower orbital margin extends a little beyond the upper orbital margin. The lateral edges are sharp, almost ridge-like and the sides are moderately inclined inwards. There are three or four regularly placed spines on the short, broadly rounded anterolateral margins and three or four similar spines line the more gently rounded lateral margin between the furrows. The posterolateral margins are curved with a few granules close behind the branchiocardiac furrow; the edge is gently rounded and leads by bluntly rounded posterior angles to the posterior margin which is a little narrower than the front.

The cervical and branchiocardiac furrows are well defined; the cervical crosses the midline in a shallow curve a little more than half the distance from the front, then runs forwards and outwards in a gentle curve to the lateral margin; crossing the margin it curves back to join the branchiocardiac furrow. The branchiocardiac furrow is bordered behind by a low ridge and terminates at the margin of the elongate-pentagonal, slightly tumid cardiac region clearly defined by a thin groove. The post-cervical furrow, separating the epi- and mesobranchial lobes (well developed in, e.g. D. rugosa Schlotheim) is reduced to a short V-shaped spur off the cardiac furrow and serves to delimit the posterior margin of an otherwise undifferentiated urogastric lobe. There is evidence of very faint epigastric nodes at the base of the front and two or three pits mark the sides of an otherwise undefined mesogastric lobe.

The dorsal surface is minutely and closely pitted and there is a scattering of fine granules over the median area of the gastric region; similar sized granules on the cardiac region are loosely arranged in a circle.

A right-hand chela is present in the nodule with the carapace. By and large it agrees with the chelae of other Dromiopsis and may be considered to belong to the present species. The propodus is subcylindrical with the inner side flattened, without a sharp upper or lower margin; on the tumid outer surface are six or seven longitudinal rows of granules with a very faint pattern of short and irregular lines or depressions in between. The fixed finger is about one third the length of the propodus; it is directed a little downwards and inwards and has a constriction proximally. A smooth concavity at the proximal end of the opposing margin is followed by three or four blunt cusps decreasing in size distally.

Discussion. In its general outline and conspicuous furrows $D$. granulata rather resembles the Danian $D$. rugosa (Schlotheim); it differs in having poorly defined gastric lobes, a prominent intestinal lobe and in being much less granulate. A weaker cervical furrow, absence of granular ornament, a flattened cardiac region and large rugose or pitted areas at the base of the mesogastric lobe serve to distinguish $D$. laevior Reuss, 1859. 
Fig. 7. Dromiopsis granulata sp. nov. from the Maastrichtian at Agatkløft. A-C: holotype, MGUH 21.587, A: dorsal view; $B$ : side view, C: frontal view, $\times 2$; D: paratype, $M G U H$ 21.588 , outer surface of right chela, $\times 3$.

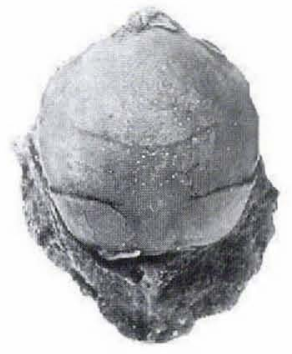

\section{A}
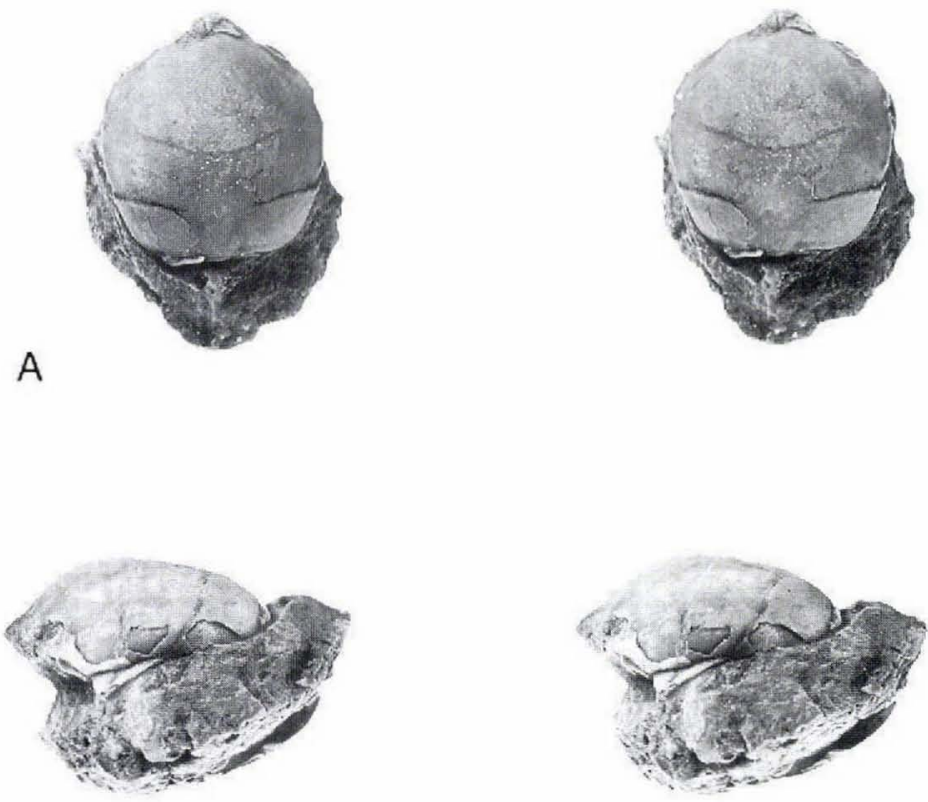

B

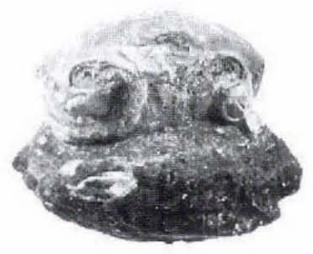

C
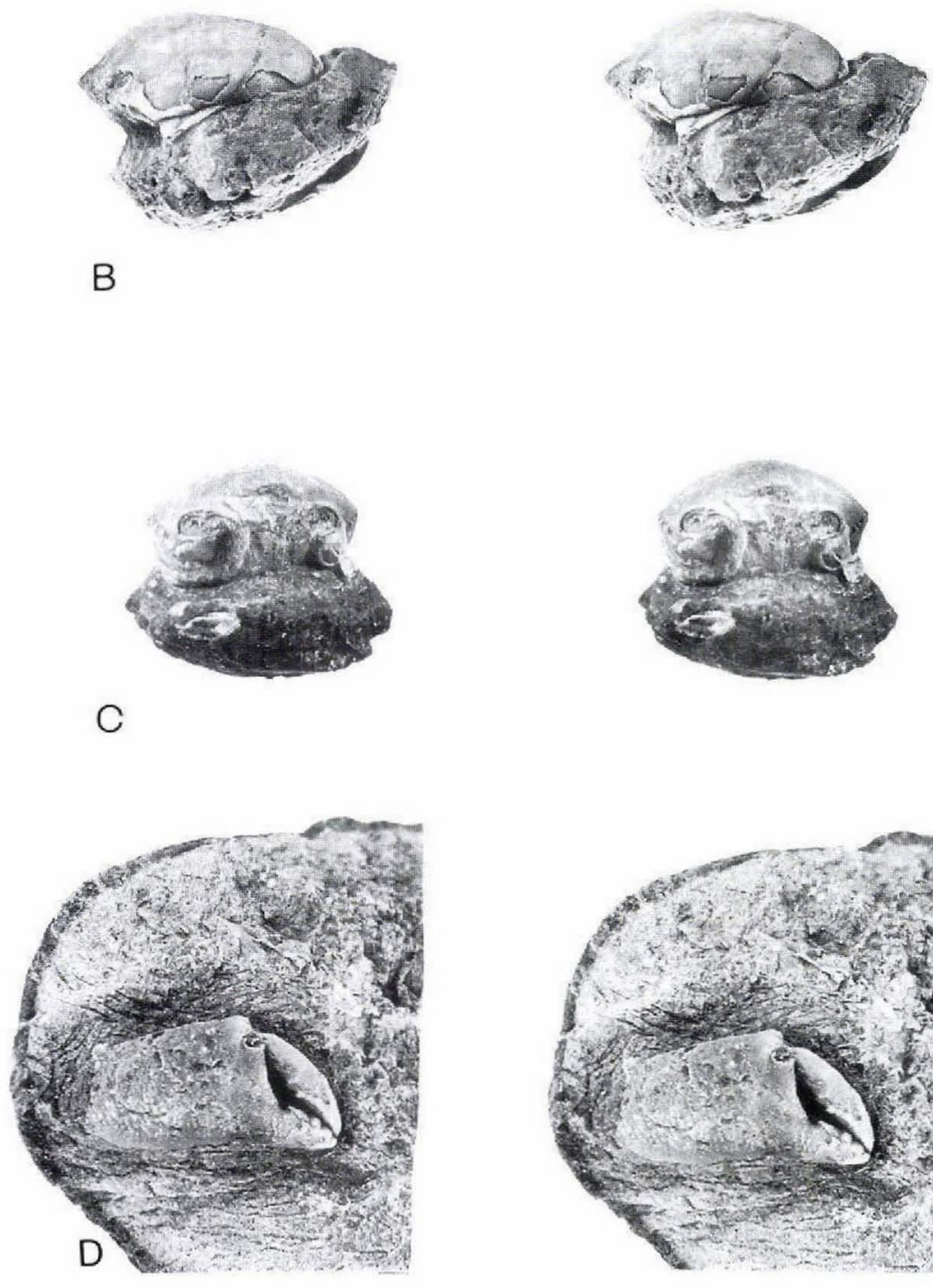

$$
\text { . }
$$


D. elegans Reuss, 1859 may be readily distinguished from $D$. granulata by its transversely ovate carapace. Dromiopsis americana Roberts, 1956, Paleocene, Vincentown Formation of New Jersey has a prominent intestinal lobe, but the cervical furrow is weaker and does not extend to the lateral margins; it differs further in having marginal spines placed only between the cervical and branchiocardiac furrows, in having rather conspicuous epi- and mesogastric lobes, and a poorly defined cardiac region.

Roberts (1956, p. 8) stated that the trend in Dromiopsis (from Dromiopsis gigas Forir, 1887) was towards a smooth carapace and a progressive reduction in the number and conspicuousness of the furrows. In this, he considered D. americana to be the culmination of the development begun by the Middle Maastrichtian $D$. elegans (which continues into the Danian) and continued through $D$. laevior, while $D$. rugosa formed a granulose and markedly furrowed line.

The present authors were not able to verify the presence of $D$. elegans in the Maastrichtian, but certainly, Danian adult forms of that species normally have weak grooves and a smooth surface. Dromiopsis granulata has a decidedly weaker cervical furrow than either $D$. gigas or D. rugosa and the surface granulation is finer, almost restricted to the gastric region. These characters together suggest that $D$. granulata forms a Maastrichtian member of Roberts's (1956) D. americana line.

Sub-section Archaeobrachyura Guinot, 1977

Superfamily Homoloidea White, 1847

Family Homolidae White, 1847

\section{Genus Eohomola gen. nov.}

Derivation of name. Eos (early) + Homola.

Type species. Eohomola adelphina sp. nov.

Diagnosis. The carapace is longer than wide, quadrangular, dorsal surface more or less flat, spinose or tubercular. The rostrum is bifid and there is a transverse metabranchial ridge extending from the widest part of the cardiac region towards the lateral margin. Orbital arrangement as in Homolopsis.

Range. Upper Cretaceous.

Discussion. The only significant character distinguishing Homola from the fossil genus Homolopsis is, according to Wright \& Collins (1972, p. 44), the single bluntly pointed and downturned rostrum in Homolopsis, as opposed to a bifid rostrum in Homola. In having a bifid rostrum with well developed horns, the new genus is distinct from Homolopsis. However, in addition to the bifid rostrum Eohomola has a transverse metabranchial ridge extending from the widest part of the cardiac region to the lateral margin. This ridge is absent from six, at least, of the eight European members of Homolopsis recognised by Wright \& Collins, 1972 (the exceptions being $H$. gibbosa (Schlüter, 1879) and $H$. tuberculata Van Straelen, 1936, the latter known only from the anterior portion of the carapace), but present in the North American species H. punctata Rathbun, 1917, and $H$. atlantica Roberts, 1962 (the latter placed in synonymy with $H$. punctata by Wright and Collins, 1972). While describing his species Homolopsis dispar Roberts (1962, p. 180) included a description of a bifid rostrum, "freed from the matrix after the plate figure has been prepared", and this feature is clearly discernible on (a plaster cast of) the specimen (made available to J. S. H. C.). Roberts also drew attention to a metabranchial ridge fused laterally to the cardiac region and this is seen to extend slightly concave to the lateral margin. In having these two eminently diagnostic characters in common with Eohomola adelphina, dispar (considered by Wright \& Collins, 1972 to be synonymous with Homolopsis punctata) fulfils the requirements for Eohomola and is here transferred to that genus.

\section{Eohomola adelphina sp. nov.} Figs 8A-C $1970 \begin{aligned} & \text { Homolopsis sp.; Rasmussen in Rosenkrantz, } \\ & \text { p. 425, 426. }\end{aligned}$

Derivation of name. Brotherly - with reference to the relationship with Homola.

Diagnosis. Eohomola with the rostral horns long, widely divergent and upturned; the transverse metabranchial ridge is straight and extends to the lateral margin.

\section{Range. Upper Campanian to Maastrichtian.}

Material. Nine carapaces. Holotype, a carapace (MGUH 21.589) from a calcareous concretion found in a boulder in the 'Oyster-ammonite conglomerate' on the western side of Agatdalen, $510 \mathrm{~m}$ above sea level in central Nûgssuaq. Most of the boulders in this conglomerate are of Maastrichtian age, but a few Upper Campanian fossils are also recorded, and this age is more in agreement with the occurrence of two carapaces from Ikorfat on the north coast of Nûgssuaq. Additional specimens, four carapaces from the 'Oyster-ammonite 
Fig. 8. Eohomola adelphina sp. nov. A: holotype, MGUH 21.589, from the Maastrichtian at Agatkløft, dorsal view of silicone rubber cast of the carapace, $\times 2$; B: paratype, MGUH 21.590 , from the Upper CampanianMaastrichtian, dorsal view, $\times 1.5 ; \mathrm{C}$ : paratype, MGUH 21.591, from the Upper Campanian-Maastrichtian at Ikorfat, dorsal view, $\times 3$.
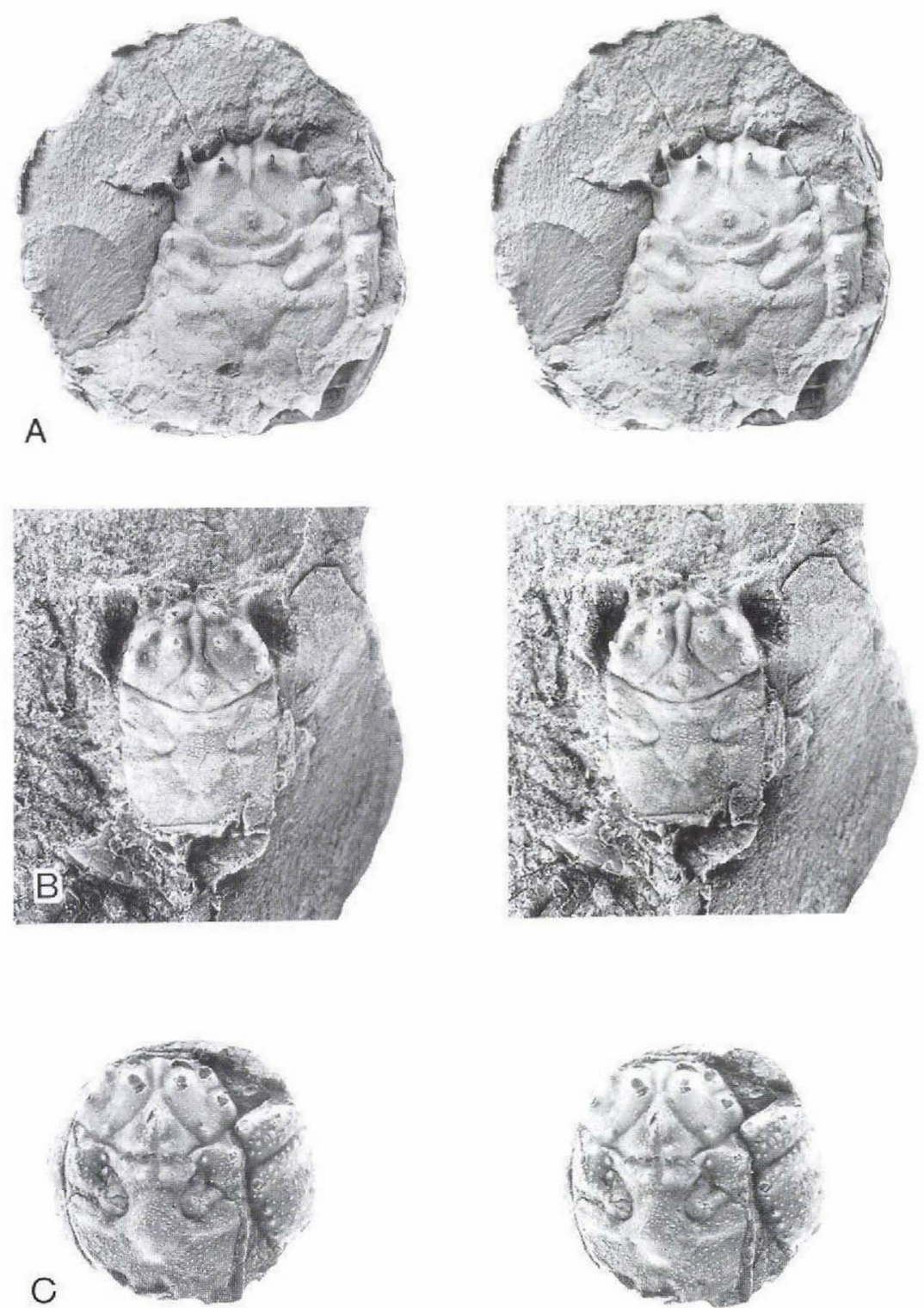

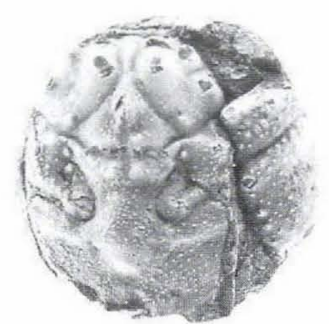

conglomerate' in Agatkløften $(405-410 \mathrm{~m})$ : two from the Upper Campanian black shales of Brudkløft $(625 \mathrm{~m})$ at Ikorfat; a single carapace of uncertain age from Saviarqat between Niaqornat and Ikorfat; and a small carapace lacking any information regarding age or locality.

Description. The carapace is subquadrate in outline, almost as wide as long (excluding the rostrum) with convex sides widest at the anterior part of the branchial region. Between the prominent line homolica the length is about one and one third to one and a half times the width. In section it is nearly flat longitudinally with the front only slightly downturned; it is slightly arched transversely, smoothly rounded at the lateral margins with deep sides inclined a little inwards. The orbitofrontal margin occupies about $60-66 \%$ of the carapace width. The rostrum is very prominent and forms a broad moderate to deeply grooved projection continuing the downward slope of the front. It is widely bifurcated with two long, upwardly directed pointed spines. The upper orbital margin is ridged and has a stout forwardly directed median spine, a longer one at the outer angle and a fine spinule at the lower outer angle. The obtusely angular cervical furrow is deep and distinct, unbroken at the midline and continuing to the margin with almost no undulation round the meso- and protogastric lobes; below the margin it curves back to join the branchiocar- 
diac furrow below the somewhat bulbous epibranchial lobe. The branchiocardiac furrow runs almost parallel to the cervical as far as the linea homolica where it turns abruptly forward for a short distance before resuming its original course.

The triangular mesogastric lobe carries a large median tubercle which may be either elongated or double-pointed, behind this is a pair of small transversely expanded tubercles. The anterior mesogastric process is devoid of tubercles; it terminates in a point between small rounded epigastric lobes each of which has a small spiny tubercle, and is constricted behind by the base of a large forwardly hooked spine forming the inner of two rising from each protogastric lobe; there is also a low tubercle close to the angle of the mesogastric lobe and cervical furrow. The hepatic furrow is deep at the margin where it curves round the outer protogastric spine when it becomes shallower and sometimes obsolete as it curves round the inner spine. The hepatic lobe has a similar spine to those on the protogastric lobe with one or two granules near its lateral base, and there is another spine on the epibranchial lobe. The very short urogastric lobe, divided by a median furrow, is tumid, almost ridged and sometimes has a few granules near the midline; it tapers rapidly as it curves round the base of the mesogastric lobe. A deep depression separates the urogastric lobe from the ridged extension of the mesobranchial lobe and there is a mesobranchial spine close to the cervical furrow. The broad tongue-shaped cardiac region has three indistinct to obsolete tubercles in an inverted triangle; from its widest part a low ridge extends almost transversely across the anterior part of the metabranchial lobe to the margin. Posteriorly a shallow depression separates the cardiac region from the almost flat metabranchial lobes and ovate intestinal region.

The dorsal surface is without pores, but anteriorly has a scattering of moderately sized well spaced granules with smaller ones intermingled; they become more densely crowded posteriorly and on tumid areas, while those on the cardiac region tend to become transversely linear.

The fragments of walking limbs preserved are long, slender elliptical in section and stoutly spinous.

The carapace length ranges from $10.0 \mathrm{~mm}$ to $15.0 \mathrm{~mm}$ and there are no structural differences among specimens from the several localities in Nûgssuaq.

Discussion. The dorsal surface of $E$. dispar, which comes from the Campanian of New Jersey, is somewhat worn causing the ornament - which could well have been spinose - to appear tubercular; it differs from $E$. adelphina in having less well developed rostral horns, the cervical furrow is shallower at the midline and the hepatic regions are more triangular, more deeply separated from the protograstric lobes causing the basal protogastric tubercle to appear as if on the hepatic region.

The arrangement of the principle spines on the dorsal surface of Homolopsis, Eohomola and Homola is essentially similar, differing little more than in strength of development and juxtaposition.

Remarks. The problem of homolids with a single or bifid rostrum/with or without a metabranchial ridge apparently emerges in the Campanian. If, as Wright \& Collins (1972) suggest, Laevihomola - with a single rostrum and smooth metabranchial lobes - is near the root stock to Homolopsis, then the single rostrum/ smooth metabranchial lobe forms would seem to be natural successors, but by Campanian times $H$. punctata and $H$. atlantica with a single rostrum had developed a metabranchial ridge (albeit weakly developed) and were followed by the strongly ridged European species $H$. gibbosa (Schlüter, 1879) in the Santonian.

The line of species with a single rostrum and smooth metabranchial lobe is carried into the Danian by way of H. planum (Van Straelen, 1936), H. brightoni Wright \& Collins, 1972, etc., to H. transiens Segerberg, 1900, and may be said to be represented at the present day by Homola mieensis Sakai, 1979 (Indo-Pacific). The line with a bifid rostrum and a metabranchial ridge appears in the Campanian (Eohomola dispar); it is represented in the Campanian and Maastrichtian by E. adelphina and possibly represented at the present time by Homola barbata Fabricius and $H$. orientalis Henderson, 1888, s.l. - the metabranchial ridge being much reduced in the latter. This may be summarised as in Fig. 9.

From the above it becomes apparent that Section 2 is isolated from Section 1 (Homolopsis sensu stricto) and Section 3 (Eohomola) and should therefore constitute a separate genus for which the name Metahomola, containing gibbosa, punctata and atlantica is here proposed, with punctata selected as type-species.

While close to some species of Homola, adelphina and dispar cannot well be included in that genus without knowledge of internal anatomy, external sexual characters etc., essential to neontological views on taxonomy, but placed in Eohomola they stand as a possible stage in development between Homolopsis and Homola. Similarly, to avoid confusion between neontological and palaeontological demands, it is considered advisable to maintain the genus Homola as envisaged by Guinot \& Richer de Forges (1981). 
Fig. 9. Cladogram showing the relationship of homolid species with earliest taxa at the top.

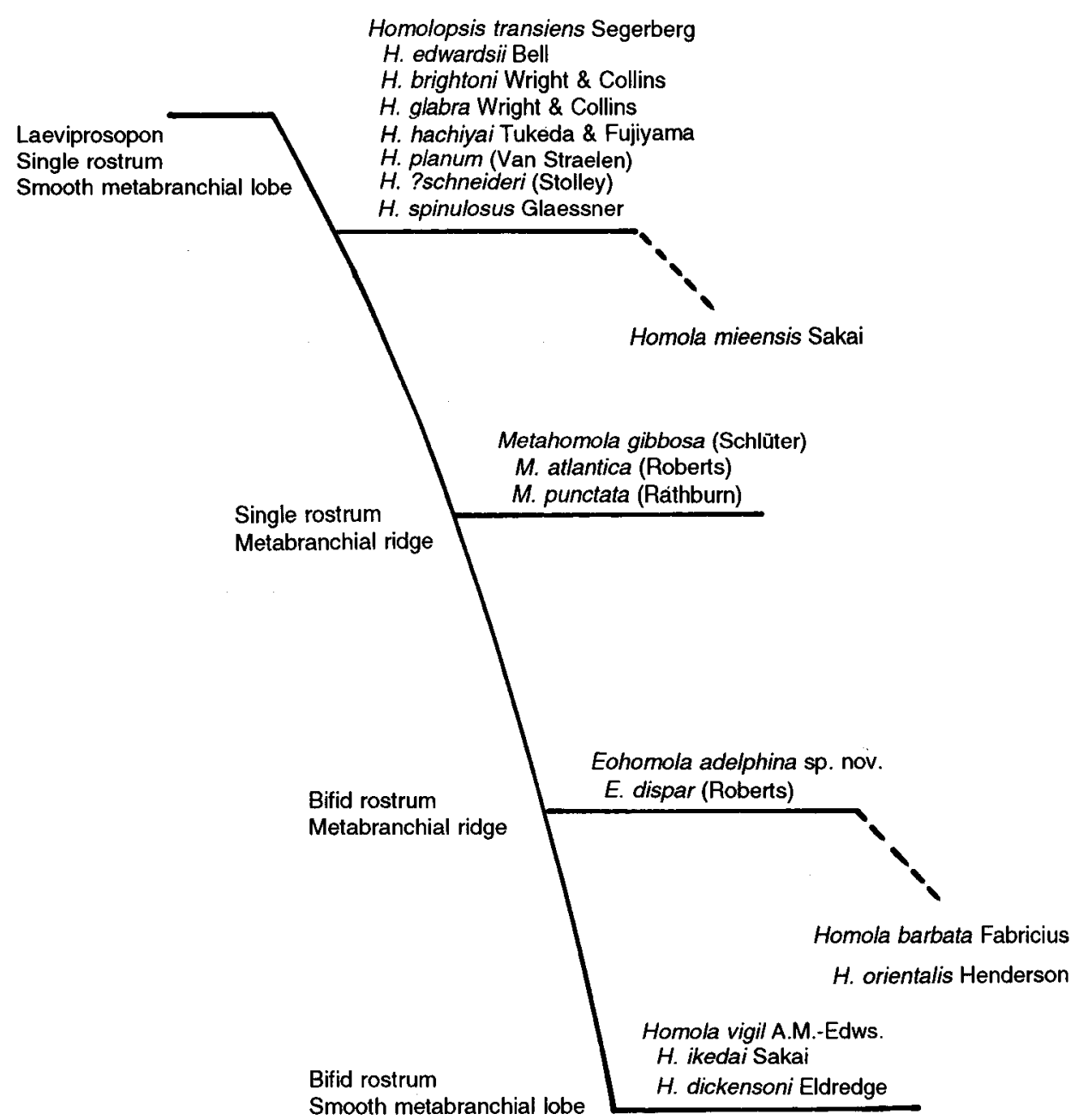

Superfamily Raninoidea de Haan, 1841

Family Raninidae de Haan, 1839

Subfamily Raninidae de Haan, 1841

\section{Genus Hemioon Bell, 1863}

Type species. By monotypy; Hemioon cunningtoni Bell, 1863. [= Raninella elongata A. Milne Edwards, 1862]

Range. Upper Albian to Coniacian.

\section{Hemioon eysunesensis sp. nov.} Figs 10A-C

1970 Raninid, Rasmussen in Rosenkrantz, p. 425
Derivation of name. From Eysunes (Old Norse: smouldering promontory) a mediaeval Norse locality in the northernmost hunting district of West Greenland. Identified by Rosenkrantz (1967, p. 380) as Nûgssuaq, where bituminous black shale was locally set on fire and smoke was seen for several years. The red-burned shales from self combustible fires are seen at many points on the coast of Nûgssuaq.

Diagnosis. A Hemioon with a truncated elliptical carapace widest at base of the lateral spines; anterolateral margins rather long, converging towards the front which is less than two thirds the width. Rostrum bifid, the horns separated by an acute V-shaped cleft and slightly longer than the outer orbital spines. The lateral spines are much stronger than those on the anterolateral margin. 

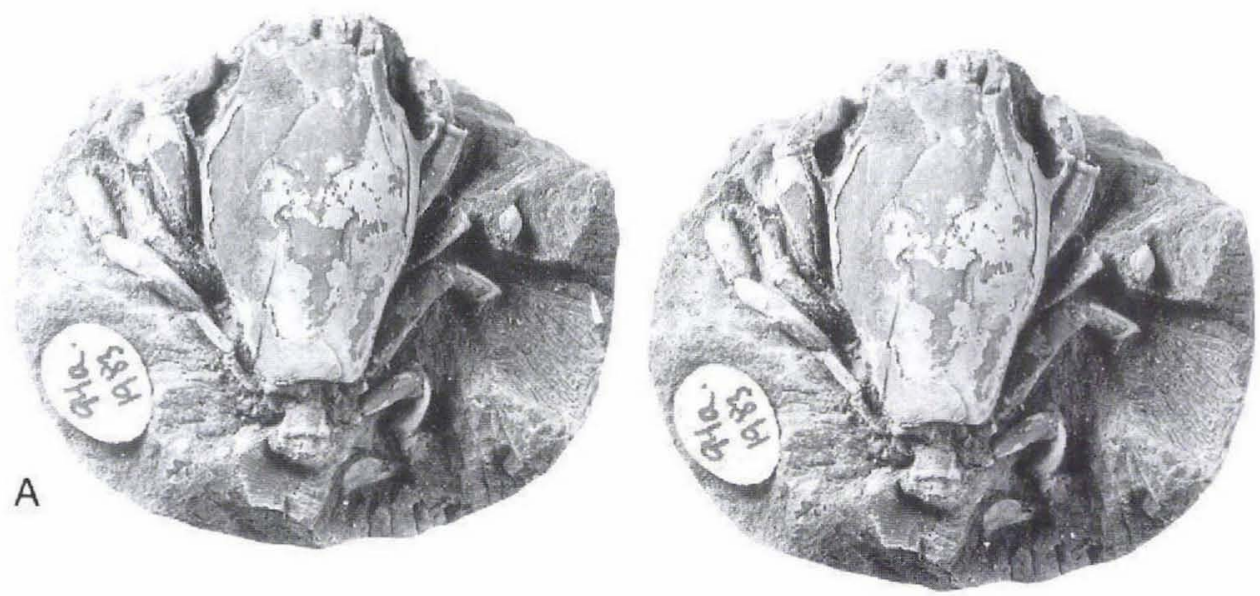

Fig. 10. Hemioon eysunesensis $\mathrm{sp}$. nov. from the

Upper

Campanian at

Ikorfat. A:

holotype, MGUH

21.592, dorsal

view of carapace,

$\times 1.5 ; \mathrm{B}$ :

paratype, MGUH

21.593, dorsal

view, $\times 1$; $C$ :

paratype, MGUH

21.594 , ventral

view showing

details of

maxillipeds and

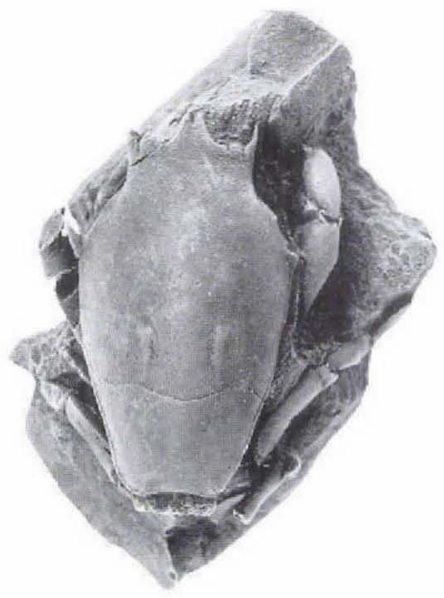

sternum, $\times 1.5$.
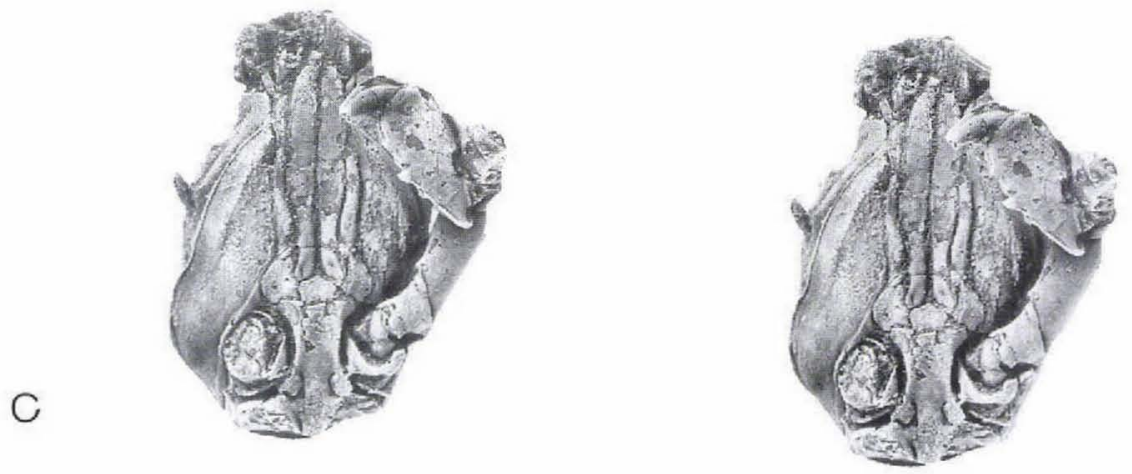
Material. 82 more or less complete carapaces, many preserving details of the ventral surface and limbs. Holotype, a carapace (MGUH 21.592) from an Upper Campanian concretion in black shale at Ikorfat, $550 \mathrm{~m}$ above sea level on the north coast of Nûgssuaq. Additional specimens, 79 carapaces in concretions from the steeply inclined strata of black shales in the profile at Brudkl $\varnothing \mathrm{ft}$ between $550 \mathrm{~m}$ and $625 \mathrm{~m}$ altitude, and 2 from the same strata immediately east of Brudkløft at $700 \mathrm{~m}$ and $885 \mathrm{~m}$ altitude. The age of the shale was determined by Rosenkrantz (1970) as Upper Campanian.

Description. The carapace is almost elliptical in outline, the width a little more than half the length, widest just behind the lateral spines about one third distant from the front; moderately rounded in transverse section, in longitudinal section it reaches its greatest height in the anterior third then curves gently to the posterior margin. The triangular spines forming the bifid rostrum are separated by a deep acutely V-shaped cleft extending onto the dorsal surface as a brief median furrow; the rostrum projects a little beyond the outer orbital spines and its sides form a regular curve with the upper orbital margin in which are two fissures separated by a broad, flatly rounded tooth. The slightly incurved outer orbital spine immediately alongside the outer fissure is rather long and slender. The orbits are narrowly ovate and a short, curved obtuse eyestalk is seen in three specimens. The anterolateral margins are deeply scalloped to a short triangular spine about midlength and again to the slender, curved, sharply pointed, forwardly and outwardly directed lateral spine, which has a length of about one sixth the carapace width. Behind the spines the margins are slightly convex to sub-parallel to the posterior third then, becoming concave, converge to the weakly excavated posterior margin. There is a sharp posterolateral marginal ridge gradually becoming obsolete towards the midlength of the carapace.

The cardiac furrows and impression of the epimeral adductor muscle scars are faint, but generally distinct; in front of these, two oblique, slightly cratered gastric muscle pits are represented as low tubercles in internal casts.

The dorsal ornament consists of small, well separated pits or pores, more closely placed in the anterior and lateral regions.

The granulated subhepatic regions have two deep furrows, one below the marginal spines, the other along the inner edge. The pterygostomian region is narrow, curved, almost rhomboidal and strongly tumid, with a granulated surface; a ridge running parallel to the pleural suture becomes obsolete shortly behind the lateral spine and a smooth rim bounds the buccal margin. The first-third sternites projecting between the third maxillipeds, are fused and onion-shaped; the anterior edge of the fourth sternites is straight and inclines very little forwards from short incisions near the midline, its sides long and slightly excavated between the first pair of legs, the posterior angles are much rounded and deeply incised either side of the midline before the adjoining fifth sternites which are about as long as the fourth, almost as wide and similarly excavated laterally.

The third maxillipeds fill the buccal cavity. The large coxopodites are closely articulated medially with the lateral part of the first-third sternites and basally with the lateral head of the fourth sternites; its outer margin is strongly convex. The subtriangular basiopodite is divided by a curved groove which reaches the distal margin between the exopodite and the ischiognath. The ischiognath expands a little distally and its outer margin is sinuous, that of the merognath is convex; broadest in its proximal third the merognath is about as long as the ischiognath. The exopodite is sinuous, about half the width of, and a little longer than the ischiognath.

The first abdominal somite is short, rather narrow, but increasing in width posteriorly; each outer angle overlaps some of the margin of the succeeding somite; the long spatulate sixth somite reaches the basis of the second pair of limbs. The telson is not preserved. In section the first somite is flat, the second-fifth are rounded and a median elevation on the third gives way to a prominent tubercle on the fourth somite. There is scattering of fine pits over the surface similar to those on the dorsal surface.

The left and right chelipeds are similar in size and form. The coxa is short, wide and curved distally. The ischium is strongly curved outwards and subdivided by furrows into five lobes. The merus is almost cylindrical and generally has a granulated dorsal ridge in the proximal and median part. The proximal articulation forms an angle of about $45^{\circ}$ with the axis. The carpus is subquadrate, its curved upper margin terminating in a stout spine; the articulation with the propodus is broadly excavate. The somewhat flattened propodus has sharp upper and lower margins; the upper margin is boldly convex distally, its almost straight proximal half laying against the merus terminates in a rounded attenuation with the slanting portion of the lower margin. On the distal part of the lower margin two or three spines increase in size distally and project in the same plane as the robust fixed finger. A spine or node near the upper margin marks the articulation of the dactylus which is gently curved and has a sharp upper and somewhat ridged outer margin. The opposing margins are serrate. The surface of the merus, carpus and propodus is rugose 


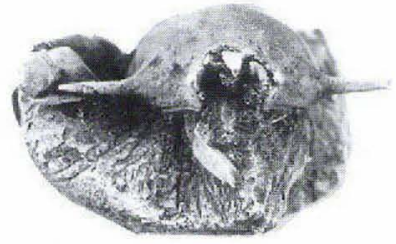

A
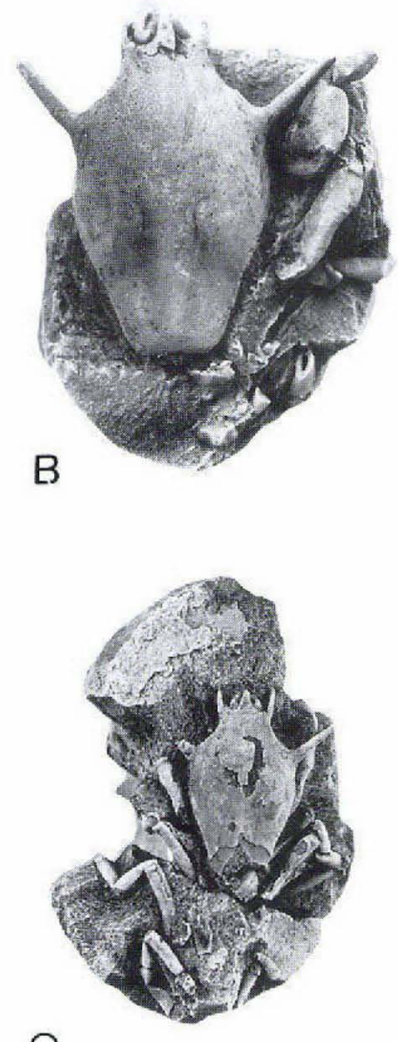

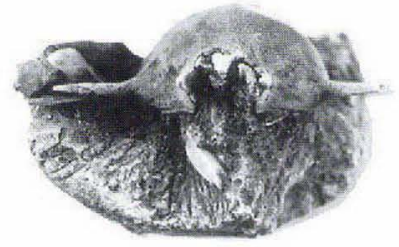

Fig. 11. Lyreidus succedanus sp. nov. from the Campanian-Maastrichtian at Turritellakløft. A-B: holotype, MGUH 21.595, A: frontal view; B: dorsal view, $\times 1.5$; C: paratype, MGUH 21.596 , showing limbs associated with detached sternites, $\times 1$.

$\mathrm{C}$
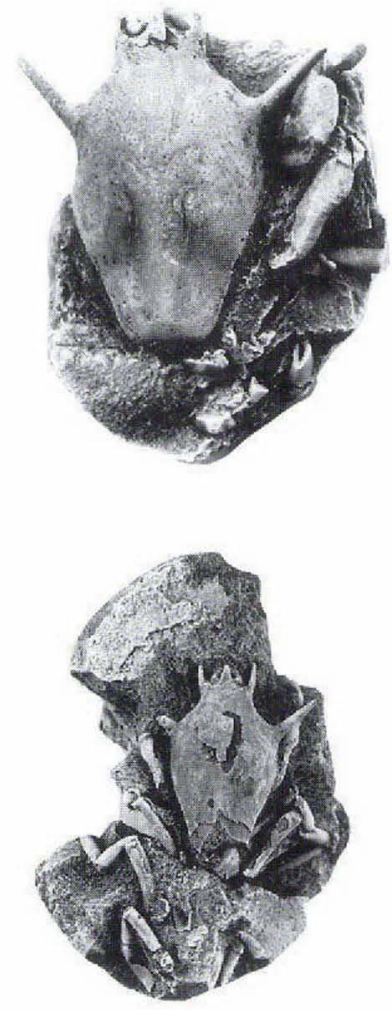

with short irregular transverse rows of pits for setae on the outer margin and a granulation on the upper side of the merus and carpus. There is a row of pits along the margins of the fixed finger and dactylus.

The second to fourth pairs of legs are rather similar in form and size. The coxa and basi-ischium are short, the merus long and slender, elliptical in section; the carpus is shorter, distally wide, almost wedge-shaped and flat; the propodus and dactylus are paddle-shaped. The fifth pair of legs are more dorsally placed, smaller, less flattened and have only a small paddle-like dactylus.

A lateral swelling typical of Bopyrus infestation occurs on the right side of one specimen.

Measurements. The carapace length, including rostrum, ranges from $10.5 \mathrm{~mm}$ to $33.5 \mathrm{~mm}$, most specimens, however, are between 15 and $30 \mathrm{~mm}$ in length. The greatest width is $0.55 \%$ to $0.60 \%$ of the length. The front occupies from $0.55 \%$ to $0.60 \%$ of the width while the posterior margin is distinctly less than a half, although not clearly indicated due to the rounded angles. The lateral spine occurs some $0.25 \%$ to $0.30 \%$ distant from the front and its median length varies from less than $1 \mathrm{~mm}$ in small specimens to more than $3 \mathrm{~mm}$ in the largest.

Discussion. Although the rostrum of Hemioon has not before been described in any detail, its bifid character was made known by Wienberg Rasmussen in correspondence with Wright \& Collins who incorporated (1972) this information in their reconstruction of $H$. elongatum (A. Milne-Edwards) and H. circumviator 
Wright \& Collins, 1972 on the evidence, in the former species of, "the insignificant base [of the rostrum] is deeply grooved, so that it may have been bifid".

The superior preservation of the present species not only provides a clearer definition of the sternum, but also a concise knowledge of the limbs and the generic diagnosis of Wright \& Collins (1972) should be modified to include these characters.

$H$. eysunesensis has affinities to both $H$. elongatum and $H$. circumviator; the former has a more slender carapace with narrower frontal and posterior margins, while in $H$. circumviator the less robust anterolateral spine is further from the front. Symnista bidentata Rathbun, 1935 was described from a single incomplete carapace from the Sucarnoochee beds of the Danian Midway Group in Alabama; it has similarly placed anterolateral and lateral spines. Both spines are abraded, however, and neither the rostrum nor sternum is known, but it is possible that this species represents a Paleocene member of Hemioon.

\section{Genus Lyreidus de Haan, 1830}

Type species. Lyreidus tridentatus de Haan, 1844 by monotypy.

\section{Range. Lower Campanian to Recent.}

Remarks. During preparation of this work a carapace from a presumed Danian boulder of flint, found in Quaternary till at Bad Oldesloe, North Germany, was described and figured by Gripp (1969) as Pseudoraninella sp. The specimen, refigured by Kummel (1972) obviously belongs to the present genus.
Lyreidus succedanus sp. nov.

Figs $11 \mathrm{~A}-\mathrm{C}, 12$

1970 Raninid, new genus; Wienberg in Rosenkrantz, p. 426.

1972 Acantharanina Wienberg; Kümmel, nom. nud.

Diagnosis. Carapace subcarinate posteriorly, the anterior portions of the branchial regions are nodose and there is a small to obscure node on the anterolateral margins. No spine is developed on the upper margin of the chelae.

Material. Holotype, a carapace MGUH 21.595, from the Cucullaea conglomerate at Turritellakløft, Campanian-Maastrichtian. Additional specimens, 192 carapaces from a series of localities ranging from Lower Campanian to Maastrichtian: Agatdalen, valley side; Agatkløften; Quvnilik, Ilugigsoq and Qilakitsoq on north side of Auvfarssuaq; Agatdalen, western slopes (incl. 'Sonja lens', Rundetårn and Jeepkløft); Qaersutjægerdal, Turritellakløft (incl. Cucullaea conglomerate); Breccianæsen and east of Ikorfat, Kangilia, Konglomeratkløft and Niaqornat on north coast of Nûgssuaq.

Description. The carapace is essentially similar to Lyreidus rosenkrantzi sp.nov. It is considerably more rounded in longitudinal section; rising rapidly behind the front it reaches maximum height at the base of the lateral spines then curves smoothly to the posterior margin. At the greatest carapace height the transverse section is steep, barrel-like, but at the base of the mesogastric lobe there develops a broadly rounded median ridge which continues to the posterior margin where it

Fig. 12. Lyreidus succedanus sp. nov. Diagrammetric reconstruction of carapace and limbs.

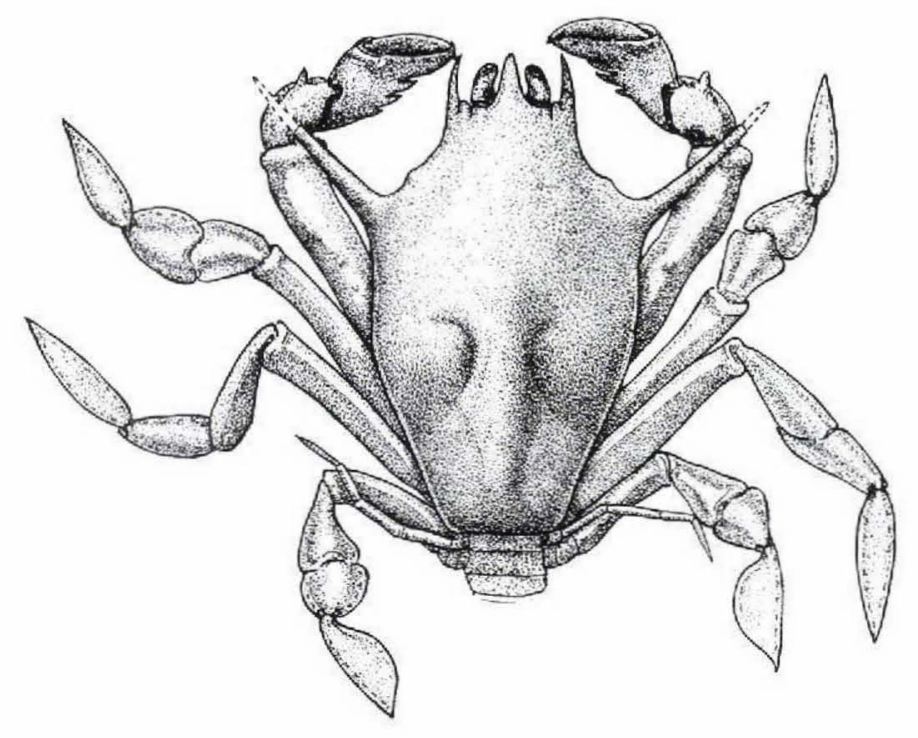




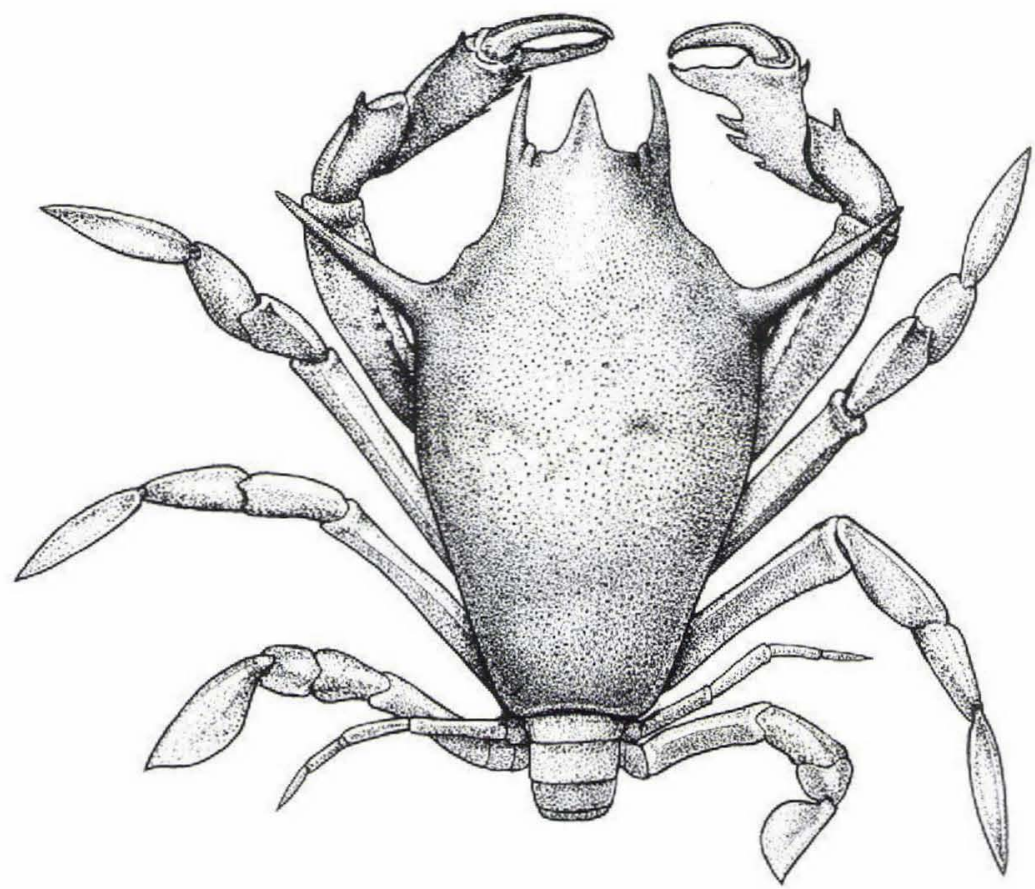

Fig. 13. Lyreidus rosenkranizi $\mathrm{sp}$. nov. Diagrammetric reconstruction of carapace and limbs. becomes flattened and broadens towards the posterior angles. Anteriorly the ridge is accentuated by deep cardiac furrows embracing round, inflated areas of the branchiocardiac region. In extreme cases the appearance is almost bopyriform, but actual occurrences of Bopyrus have been observed in only a few individuals. The median ridge and tumid areas are particularly noticeable in young carapaces but both features become gradually less prominent, though never entirely obscure, as growth advances. The strong, stout lateral spine occurs a little more than one third distant from the rostral tip; its angle of inclination to the longitudinal axis varies from about $38^{\circ}-43^{\circ}$. The cervical furrow crosses the midline in a broad $\mathrm{V}$ and its extremities are directed towards the base of the spines. The orbital peduncle is almost as long as the outer orbital spine and curved in much the same plane.

The first-third sternites are fused, rounded triangular and about one third maximum width of the sternal plate; the head, or anterior part of the fourth sternites is broadly triangular, it is deeply concave behind for the chelae; the head of the fifth sternites is noticeably wider than that of the fourth sternites, and the portion between the first pereiopods is wider than that between the chelipeds and has deeply cleft sides. The sides of the narrow sixth sternites are raised.

The chelipeds are similar to those of $L$. rosenkrantzi but lack the spine on the upper margin of the propodus.
Discussion. This species is discussed with the following species after the description of $L$. bispinulatus.

\section{Lyreidus rosenkrantzi $\mathrm{sp}$. nov.} Figs 13, 14A-C, 15A-B

Derivation of name. In honour of Professor A. Rosenkrantz, leader during 1938-1968, of the Danian expeditions to Nûgssuaq in West Greenland, and promoter of numerous palaeontologic and biostratigraphic studies on the Senonian and Danian in Denmark and Greenland.

Diagnosis. Carapace with a small node on the anterolateral margin and a stout lateral spine forming an angle of about $30^{\circ}$ with the carapace midline; dorsal surface evenly arched, smooth, with a fine scattering of pits; chela with distal spine on the upper margin of the propodus.

Material. Holotype, a carapace, MGUH 21.597, from a calcareous concretion of bituminous clay of Maastrichtian age in the 'Oyster-ammonite conglomerate' included in the Lower Danian bituminous shale of the Kangilia Formation, Thyasira Member at an altitude of $510 \mathrm{~m}$ on the western side of Agatdalen. Additional specimens, 1240 carapaces of which 540 were found between 510 and $530 \mathrm{~m}$ altitude at the type locality and 
Fig. 14. Lyreidus rosenkrantzi sp. nov. from the Maastrichtian at Agatkløft, $\times 1.5$. A: holotype, MGUH 21.597, dorsal view; B: paratype, MGUH 21.598, ventral view showing details of chelipeds; C: paratype, MGUH 21.599, ventral view.
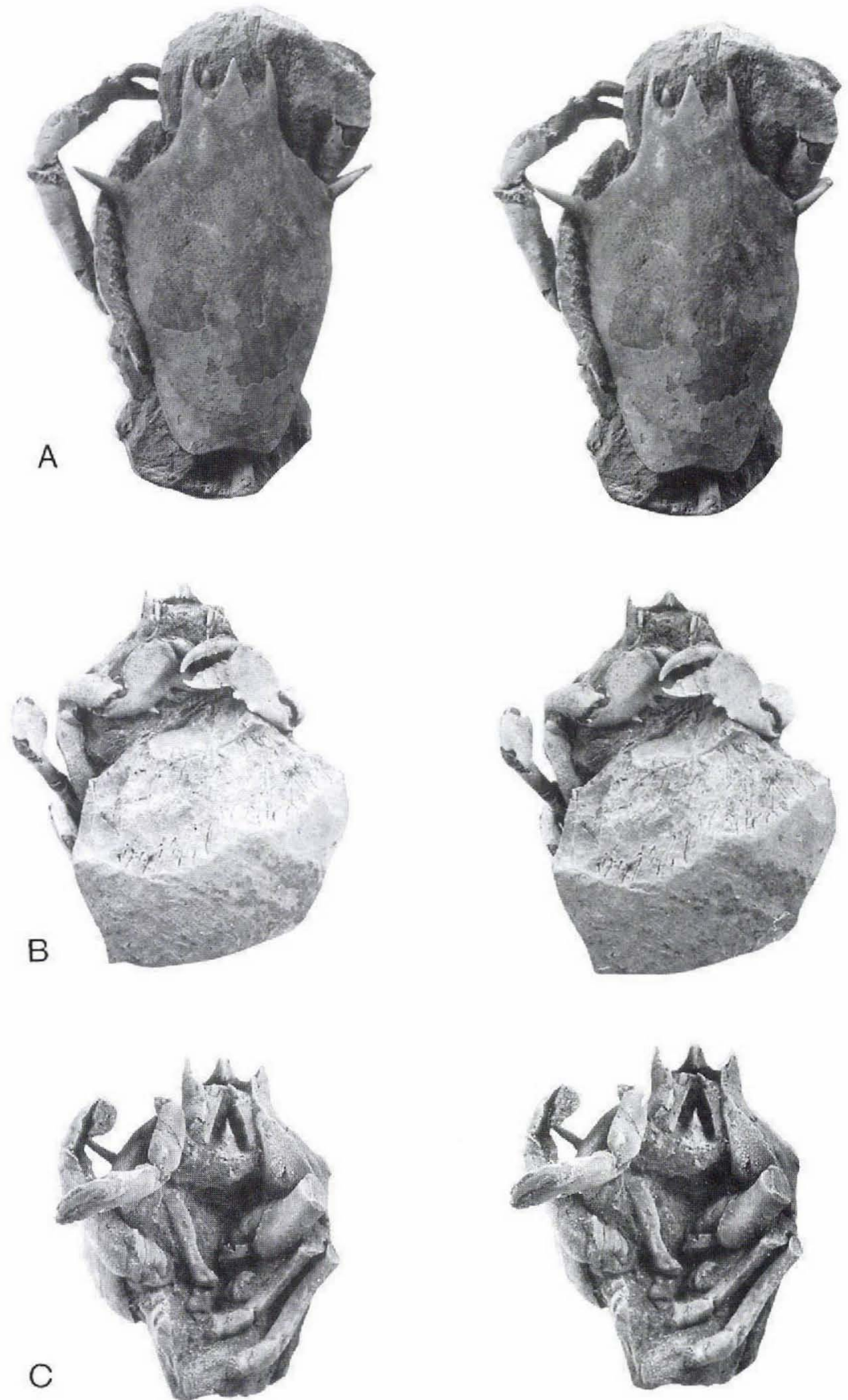

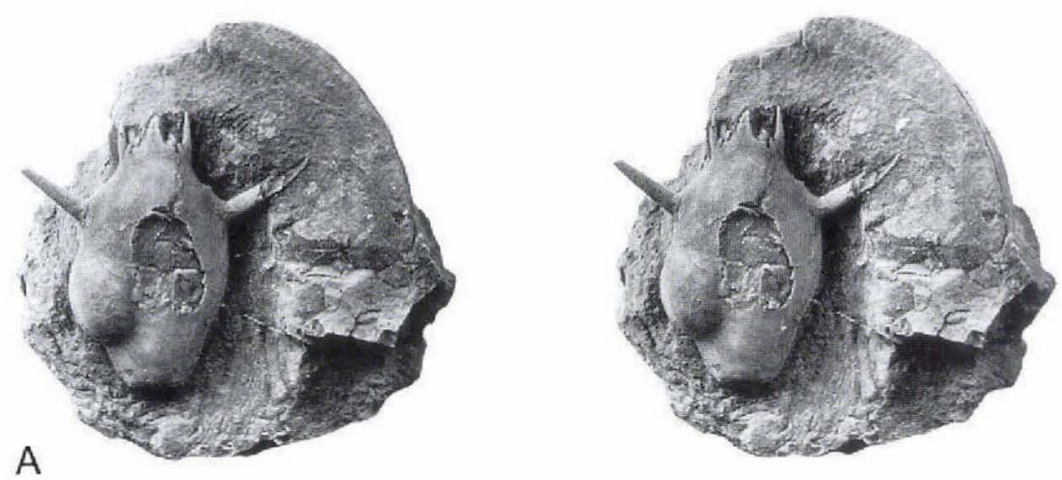

Fig. 15. Lyreidus rosenkrantzi sp. nov. from the Maastrichtian at Agatkløft. A: paratype, MGUH 21.600. carapace with typical bopyriform swelling on left branchial region, $\times 1$; B: paratype, MGUH 21.601 , dorsal view, $\times 1.5$.

B

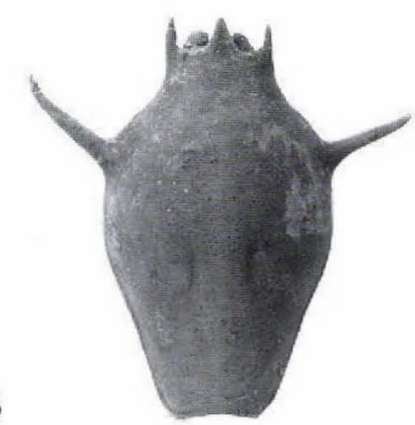

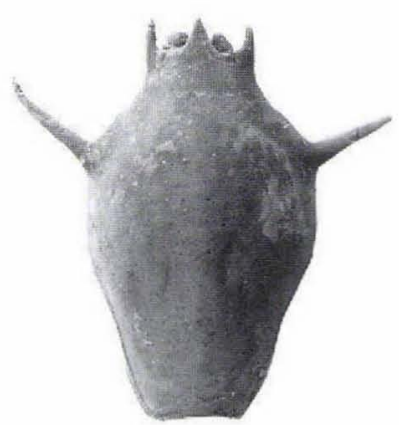

700 of similar age are from Agatkløften (Loc. 1 and 2), altitude $405-410 \mathrm{~m}$. The concretions are all of the same sedimentological character as the holotype.

Description. The carapace is almost elliptical in outline, strongly curved in transverse section, slightly convex in side view, without a postfrontal ridge or depression and highest at the anterior third. Breadth, at base of lateral spines, about five eighths total length (overall width rather more than the total length). There is a small protuberance on the anterolateral margin set rather closer to the lateral spine than to the front; from this protuberance the margin is concave and converges rapidly towards the front. The frontal margin is about half the carapace width; the rostrum is simple, triangular, pointed and slightly concave dorsally. There are two fissures in the upper orbital margin and the slightly protruding spine between them is broad, flat, and rounded apically. The outer orbital spine leading immediately from the outer fissure is as long, or just longer than the rostrum and slightly incurved. The orbital peduncle is short and curved. The very long, straight to slightly curving lateral spine occurs a little more than one third distant from the front; it forms an angle with the longitudinal axis of between $23^{\circ}-39^{\circ}$, and $0-15^{\circ}$ upwards from the horizontal plane; in some specimens the distal end curves slightly forwards. In juvenile specimens with a carapace length of $10 \mathrm{~mm}$ to about $22 \mathrm{~mm}$ the spine shows a positive allometric growth rate compared to the length of carapace. In larger specimens the length of the spine does not increase, but remains between 5 and $10 \mathrm{~mm}$. The uniform length of right and left spine and the undamaged point shows that this is not the result of damage or a reduced size after regeneration.

From a shallow constriction immediately behind the spines the posterolateral margins are weakly convex and subparallel for about half their length when they become concave and converge to narrowly rounded posterior angles. Along the concave portion the marginal edges are sharp. The posterior margin is about as wide as the front.

Very shallow cervical furrows curve from each side of the dorsal midline from a point a little less than half the overall carapace length, they are directed towards, and at a similar angle to the midline of the lateral spines, becoming obsolete about mid-orbital width; a pair of posterior gastric pits occur at their basal third. Short cardiac furrows are generally more distinct. Faint impressions of attractor epimeralis muscle scars are seen in well preserved specimens and internal casts also show attachments for posterior gastric and internal mandible adductor muscles. The ornament of the dorsal surface 
including rostrum and spines, consists of small scattered pits. The lateral margins, outer orbital spines, and ventral surface of the lateral spines are granulated, but only rarely are granules found on the frontal margin.

The pterygostomian process has two deep submarginal furrows and is granulated, as is the rather narrow branchiostegite which has a median fold. A broadly triangular epistome intrudes about half way into the buccal cavity.

The abdomen reaches almost to the bases of the chelipeds, its width is distinctly narrower than the posterior margin and further restricted between the first and second somites. The first somite is short and rather wide with margins converging anteriorly, the anterior edge is straight, the posterior one concave. The succeeding somites are long and more curved round the axis with distinct pleural areas forming an angle with the dorsal surface. The edges of the second and dorsal surface of the third to fifth somites are faintly granulated and the fourth has a prominent median tubercle. The sixth somite is long, narrow and spatulate with concave sides fitting between the bases of the first pair of pereiopods. The triangular telson has serrated sides and a scattering of fine pits over the surface. Overall, the abdomina are insufficiently preserved to allow determination of the sexes.

Antennules and antennae are vestigial and only indicated in a single individual where the rostrum is broken off. The mandibles, exposed in very few specimens, have a rather long gnathobase with undivided masticatory surface. The third maxillipeds have a short, triangular protopodite, a long, flat, undivided exognath and an endognath with a long, flattened ischiognath and merognath.

The chelipeds are robust and the left and right are more or less equal in size; the coxa is short with a granulated surface and a prominent tubercle on the inner side; the basi-ischium is curved, granulated and divided into five lobes; the long, almost cylindrical merus is flattened on the inner side proximally, it is finely granulated on this surface and sometimes on the distal part of the outer side, the proximal articulation forms an angle of about $45^{\circ}$ with the angle of the joint. The proximal and distal articulations of the short, curved carpus are almost perpendicular to each other, but still well separated on the underside. The palmar portion of the large, flattened propodus is subquadrate; the upper margin is sharp, almost in line with the carpal articulation and there is a small spine distally; the fixed finger extends almost at right angles to the upper margin and is almost as long as the palmar width; on the lower margin up to four, though generally three, spines increase in size distally; the surface is ornamented simi- larly to the merus. The dactylus is long, slender, gently curved with a rim along the upper margin and there are a few pits along the serrate opposing margin.

The first to fourth pairs of pereiopods are slender and closely placed. The coxa is short, the basi-ischium slightly curved and subdivided by furrows into four lobes. The long slender merus is elliptical in section and is granulated along its sharp upper margin. The carpus is flat and expanded distally, that on the second pereiopod has a distal spine on the upper margin. There is a backwardly projected prolongation of the propodus along the distal part of the carpus, and the propodus and dactylus together with the distal part of the carpus form a paddle. The more dorsally placed fifth pair of pereiopods are small and very slender; the lower and inner margins of the coxa, basi-ischium and merus are granulated. The merus and carpus are slightly elliptical in section. The propodus and dactylus are not preserved and there is no indication of expansion towards the distal end. The carapace length from the base of the rostrum to the posterior margin ranges from $10.5 \mathrm{~mm}$ to $37.8 \mathrm{~mm}$. The width averages 0.63 of the length and remains constant throughout growth.

By and large this species seems to have attained a larger size than $L$. succedanus. As growth advances in both species there is a marked tendency for the front to become narrower in proportion to the width and there is a slight progression of the lateral spine towards the front.

Discussion. See general discussion following Lyreidus bispinilatus sp.nov.

\section{Lyreidus bispinulatus sp. nov.} Figs 16A-D

Derivation of name. With reference to the single lateral spine on either side.

Diagnosis. A Lyreidus with a truncated, almost elliptical carapace with a pair of lateral spines one third distant from the front.

Material. Six more or less incomplete carapaces. Holotype, a carapace (MGUH 21.602); it shows the complete dorsal surface of the carapace except its posterior end (which is preserved on two paratypes from the same locality) from a sandstone bed of the Turritellakløft Member of the Middle Paleocene Agatdal Formation in the large Turritellakløft section, central Nûgssuaq. Additional specimens, four carapaces from the type locality, and one from the corresponding sandstone bed in 

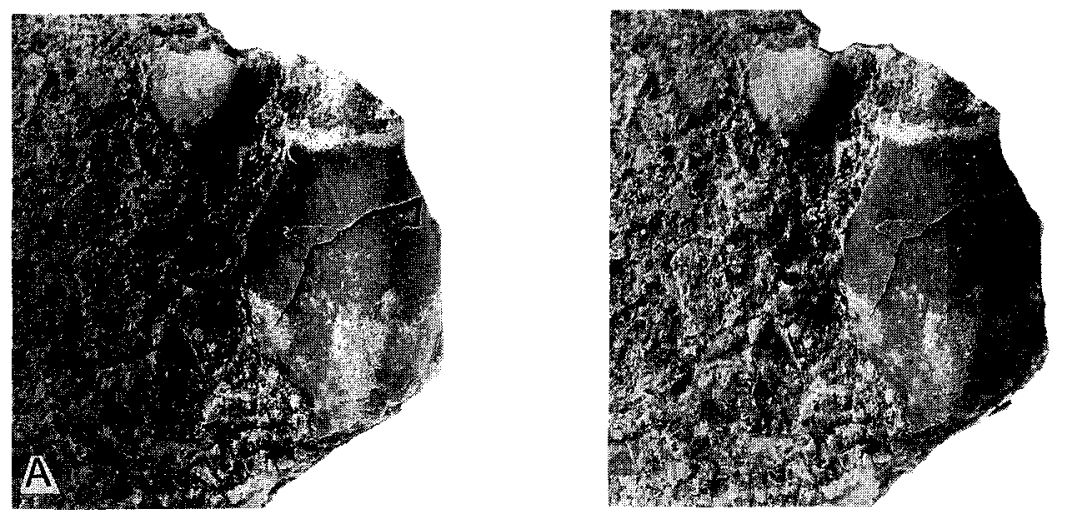

Fig. 16. Lyreidus bispinulatus sp. nov. from the Middle Paleocene at Turritellakløft, $\times 2$. A: holotype, MGUH 21.602, dorsal vicw of carapace; B-D: paratype, MGUH 21.603, B: dorsal view, $\mathrm{C}$ : lateral view; D: frontal view.
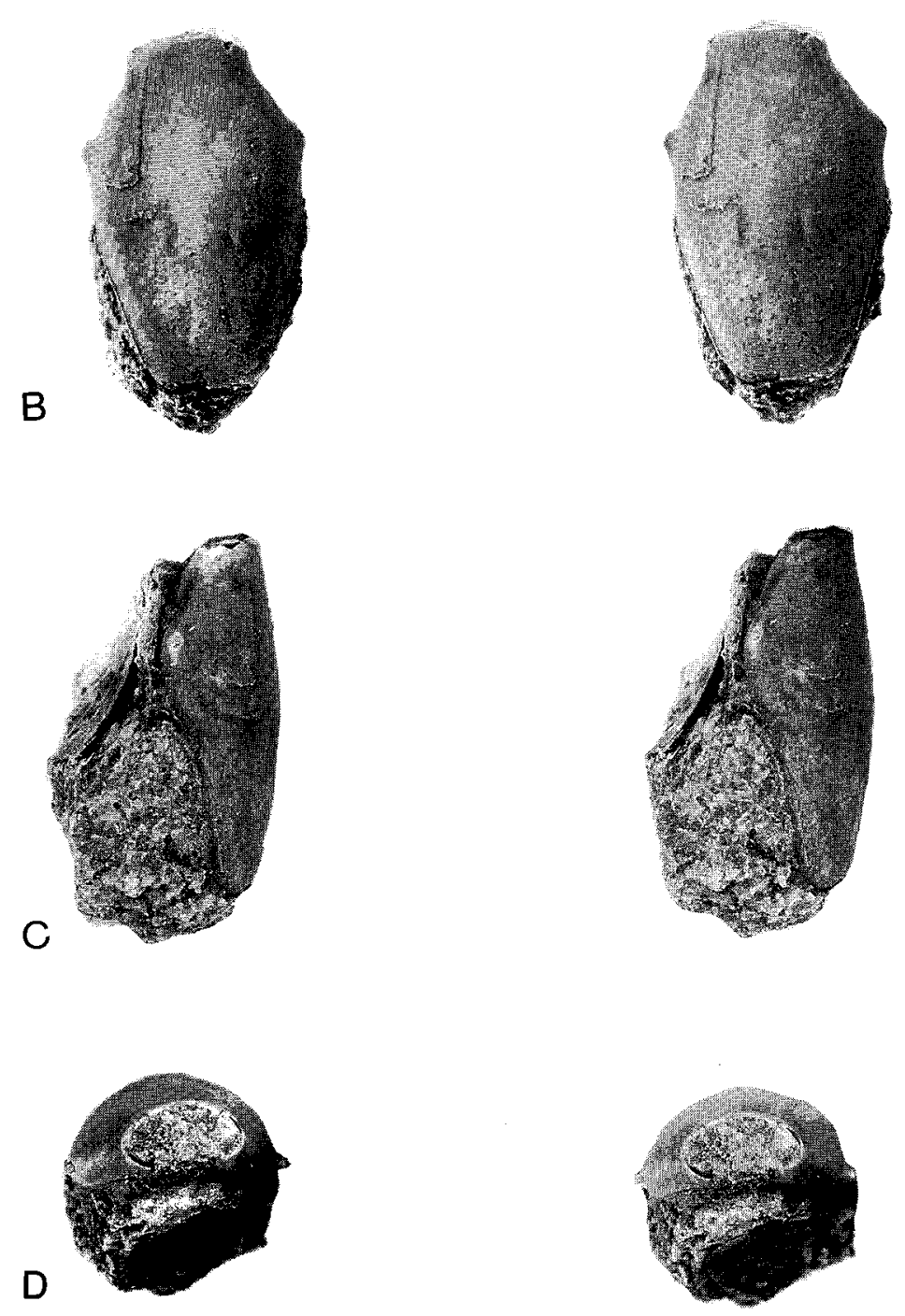
the smaller profile on the south side of the gorge, opposite the Turritellakløft section.

Description. The carapace is truncated elliptical, length (at base of rostrum) rather less than twice the width and widest just behind the lateral spines about one third distant from the front. From the rather short curved spine at the lateral angle the anterolateral margins are strongly convergent, slightly convex to nearly straight for about two thirds their length then become almost parallel to the front. No secondary spinule or elevation is developed. The front, being rather more than half the carapace width, is rather wide for the genus. The rostrum is simple, broadly triangular without a median furrow. The orbits are forwardly directed and there is a rounded tooth between the two upper orbital fissures. The outer orbital spine if complete, as it appears to be on the holotype, is rather small. The posterolateral margins are convex and converge to well rounded posterior angles leading to the posterior margin which is about as wide as the front.

The most complete carapace has a length of $19.0 \mathrm{~mm}$ (excluding rostrum) and the greatest breadth (excluding spines) of $11.5 \mathrm{~mm}$; the orbitofrontal width is $6.5 \mathrm{~mm}$. The holotype is a little smaller, the greatest width being $10.0 \mathrm{~mm}$ and in the other, less complete, specimens it ranges from $8.2 \mathrm{~mm}$ to $12.0 \mathrm{~mm}$.

The dorsal surface is finely porose with sometimes a fine granulation along the well rounded anterolateral edge and along the posterolateral edge well behind the lateral spines. Faint, slightly curving lateral cardiac furrows (epimeral attractor muscle scars) are situated a little posterior to midlength.

Discussion. Both $L$. succedanus and $L$. rosenkrantzi retain elements of a cervical furrow almost identical with that of Lyreidus tridentatus. This and the advanced nature of the sternites - essentially Lyreidus - the position of the lateral spines, the narrow front and its armature, clearly places succedanus and rosenkrantzi in Lyreidus. The presence of $L$. succedanus in the Lower Campanian substantially extends the known stratigraphic range of the genus and the geographical range of the genus is considerably extended northwards.

Glaessner (1960) and Griffin (1970) subdivided Lyreidus into three groups according to the presence or absence of lateral spines and Feldmann \& Zinsmeister (1984, fig. 6) provided a complete table detailing ten fossil and/or Recent species. Of these the first group contains one Recent species, Lyreidus stenops, with no lateral spines, in the second group, typified by L. trispinosus, five species have one pair of spines and in the third group, that of Lyreidus channeri Wood-Mason, 1885 , four species have two pairs of spines.

Goeke (1985) transferred the Recent Lyreidus bairdii Smith, 1881 (= Raninoides nitidus A. Milne Edwards, 1880) and Lyreidus channeri Wood-Mason, 1885 which have two pairs of spines to Lysirude, Goeke 1985, and included Lyreidus griffini Goeke, 1985. One of the distinguishing characters of Lysirude is the presence of an obsolete spine on the anterolateral margin "represented by a distinctly irregular marginal shape and often a small tubercle" (Goeke, 1985). Although such a spine is found on Lyreidus succedanus and $L$. rosenkrantzi, it is the only diagnostic feature (preserved) in common with Lysirude. Feldmann (1989) was of the opinion that "the distinguishing characters selected by Goeke (1985) to characterise his new genus ... would be used to make distinctions between taxa at the species not the genus level", and considers Lysirude a junior subjective synonym of Lyreidus.

Both $L$. succedanus and $L$. rosenkrantzi belong to the third of the above mentioned groups - that of $L$. channeri, a Recent species. The difference in the angle of the spines, $38^{\circ}-43^{\circ}$, in $L$. succedanus and $23^{\circ}-39^{\circ}$ in $L$. rosenkrantzi, together with the median 'ridge' and inflated branchial regions of the former, readily distinguishes these two species. Feldmann (1989) published a considerable revision of Lyreidus alseanus Rathbun, 1932 from Eocene to Oligocene deposits of Washington and Oregon and there is in the development of a distinct median ridge a close similarity between that species and L. succedanus; it differs, however, in having rather more prominent anterior spines, the outer orbital spines are finer and straighter, and in details of the sternites. Feldmann (1989) considered that $L$. alseanus was closely morphologically related to the Recent $L$. channeri and it is evident that this lineage must be extended to include L. succedanus.

Lyreidus bispinulatus and the German Danian Lyreidus sp. have only a single pair of spines and are the oldest known members of the $L$. trispinosus group. Gripp (1969) described the anterolateral margin of Pseudoraninella $\mathrm{sp}$. [=L. sp.] as being weakly concave; the frontal margin is remarkably wide, almost two thirds of the carapace width. The long, almost straight lateral margin and concave posterolateral margin approaches that of Lyreidus paronai Crema, 1885 which also has long spines and a comparatively wide front. L. bispinulatus differs from both of the previous species in having a narrower frontal region and a more eventy rounded posterolateral margin and in this respect compares favourably with that of the Miocene Lyreidus antarcticus Feldmann \& Zinsmeister 1984 (the most southerly 
known member of the genus), but has a comparatively wider front and is somewhat narrower in proportion to length. L. bispinulatus is also similar to the Miocene Lyreidus elegans Glaessner, 1960 (synonimised by Griffin, 1970 with $L$. tridentatus), but differs in having a wider orbitofrontal margin.

\section{Genus Notopocorystes M'Coy, 1849 Subgenus Cretacoranina Mertin, 1941}

Type species. Raninella? schloenbachi Schlüter, 1879, by original designation.

Range. Middle Albian to Santonian.

\section{Notopocorystes (Cretacoranina) paututensis sp. nov. \\ Figs 17A-B}

Derivation of name. From Pautût, the type locality.

Diagnosis. A Creticoranina with an elongate rostrum, weakly bifid apically. The cervical furrow is entire and the frontal area is depressed leaving the anterior margin of the hepatic region lobulate.

Material. Holotype. The impression of the dorsal surface of a carapace. MGUH 21.604, and paratype, MGUH 21.605, an impression of the surface of a carapace. Both specimens found on slabs of red-burned shale in the old landslide fan at Pautût, $480 \mathrm{~m}$ above sea level, on the south coast of Nûgssuaq. The sediments are referred to the Upper Santonian or Lower Campanian.

Description. The carapace is subovate in outline, the width about two thirds the length and widest shortly behind the cervical notch about one third distant from the front. There is no median carina, instead the dorsal surface is slightly tumid, almost flat, but this may to some degree be due to secondary flattening in the shale. The short anterolateral margin is imperfectly preserved, but basal scars indicate there was a spine a little behind the outer orbital spine, one just before the cervical notch, one on the epibranchial lobe and another very small one immediately behind it. The posterolateral
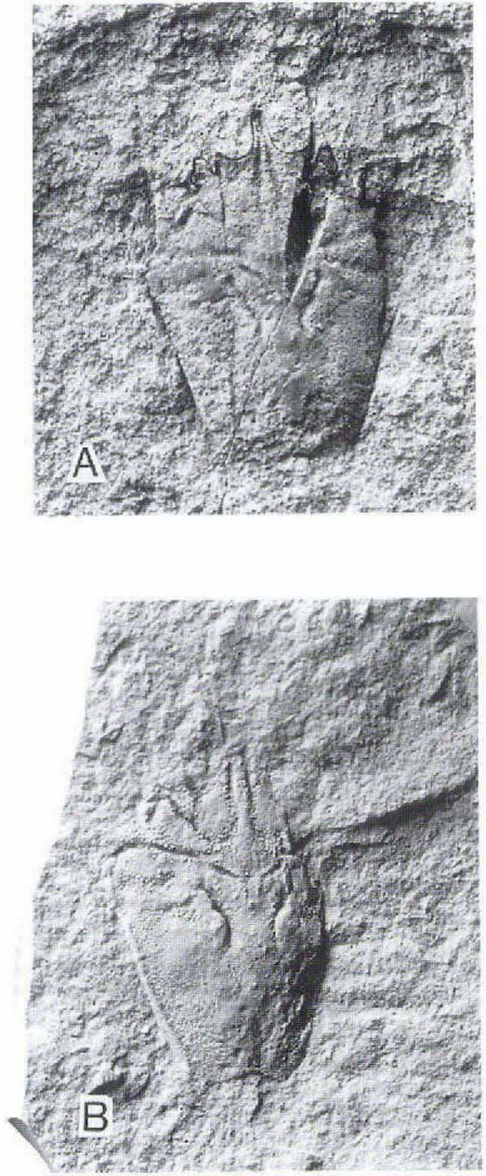
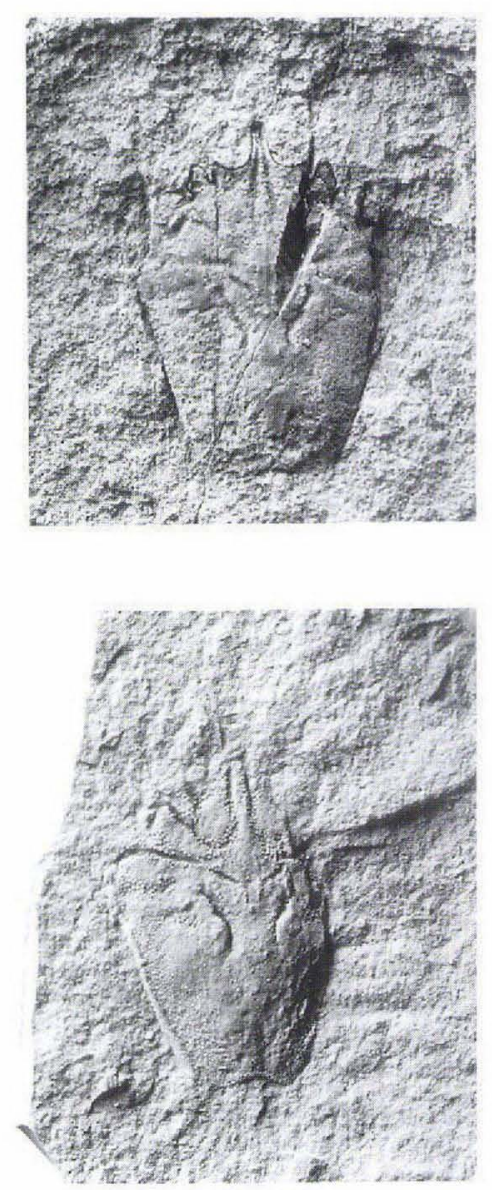

Fig. 17. Notopocorystes (Cretacoranina) paututensis sp. nov. from the Lower Campanian at Pautût, $\times 3 . \mathrm{A}$ : holotype. MGUH 21.604, dorsal view of carapace; $B$ : paratype, MGUH 21.605, dorsal view of silicone rubber cast of the carapace. 
margin is weakly convex and bordered by a well rounded ridge which narrows considerably as it approaches the posterior angles and bounds the posterior margin. The posterior margin is narrower than the front and moderately concave. The orbitofrontal margin is incomplete, but appears to have occupied about two thirds the carapace width. There is a distinct long, narrow rostrum weakly bifid apically with a prominent ridge separated by fine grooves from the raised margins which continue as a rim across the inner slightly concave portion of the upper orbital margin and end in a point at the inner orbital fissure. The two wide fissures are separated by a flat, broad-based, probably pointed tooth. The base of the outer fissure is rather deeper than the inner and, together with the projected base of the outer orbital spine suggests the orbits were directed obliquely outwards. The rostral grooves run back and delimit the anterior mesogastric process.

From the margin the cervical furrow runs obliquely forward, then back in a gentle curve to a little forward of the outer angle of the mesogastric lobe, then turns sharply to the angle and just as sharply inward, forming a zig-zag; it is interrupted near the midline by a pair of longitudinal processes uniting the meso- and urogastric lobes and ends in a pit at the midline. The hepatic furrow issues from the groove delimiting the mesogastric lobe just above the 'zig-zag' and progresses to the margin in a series of three loops, the outermost enclosing a node at the base of the first anterolateral spine. The areas contained within the loops are tumid - a condition more noticeable on internal moulds. Deep grooves, with a pit anteriorly, on either side of the rather wide urogastric lobe converge to the widest part of the cardiac region. The branchiocardiac furrow commences just lateral to the (urogastric) pit and runs back to the lateral margin at an angle divergent from the cervical furrow. There is a small median granule on the urogastric lobe and the internal mould shows two feeble granules on the widest part of the cardiac region and another on its much attenuated base. The epibranchial lobe, vaguely discernible on the outer surface, is lozenge-shaped and a granulated depression separates the meso- from the metabranchial lobe.

Apart from the generally depressed areas, other granules on the outer surface are concentrated towards the lateral margins, in continuation with the rostral grooves and along the margins of the cervical and hepatic furrows; the bases of these furrows and the mid-dorsal areas are smooth.

Discussion. In retaining an entire cervical furrow $N$. (C.) paututensis would appear to be close to the early, Albian species $N$. (C.) broderipii (Mantell, 1844), the
Cenomanian $N$. (C.) syriacus Withers, 1928 and $N$. (C.) ornatus Wright \& Collins, 1972, and the more or less contemporary $N$. (C.) harveyi (Woodward, 1896) from the Senomanian, Nanaimo group of Vancouver Island and Hornby Island, British Columbia. $N$. (C.) broderipii and $N$. (C.) syriacus differ from the present species in having a shorter rostrum and a more or less obscure median ridge running the whole length of the carapace. While lacking a median ridge $N$. (C.) ornatus is immediately distinguished by its coarse ornament. The median ridge of $N$. (C.) harveyi is described by Woodward (1898) as faint, but this large species may further be distinguished in having a deeply incised rostrum and its shorter distance from the inner orbital notch. The anterolateral spines of $N$. (C.) paututensis have been determined from undulations along the margin and observations are therefore questionable, but by and large they agree with those of $N$. (C.) harveyi, although in the latter the anterior pair are close together, almost bifid.

\section{Genus Laeviranina Lörenthey \& Beurlen, 1929}

Type species. Ranina (Laeviranina) budapestiniensis Lörenthey \& Beurlen, 1929, by subsequent designation of Glaessner, 1929.

Range. Paleocene Danian to Recent.

\section{Laeviranina borealis sp. nov.} Figs 18A-C

Derivation of name. Indicating a northern species.

Diagnosis. Carapace with a sinuous postorbital ridge in front of the lateral spines and weak cardiac furrows; dorsal surface finely granulated.

Material. Holotype, a more or less complete carapace (MGUH 21.606) and 7 additional specimens found in calcarenite concretions from the Turritellakløft Member of the Agatdal Formation in the great profile of Qaersutjagerdal in Nûgssuaq. They were found in the uppermost sandstone with concretions just below the Abraham Member of black shales and tuff.

Description. The carapace is subovate, almost elliptical in outline; width about two thirds of the carapace length, widest at or a little anterior to midlength. It is rather strongly curved in transverse section; a noticeable postorbital depression is bounded by a slightly sinuous ridge, convex medially, reaching the margin just anterior to the lateral spine, from the depression 

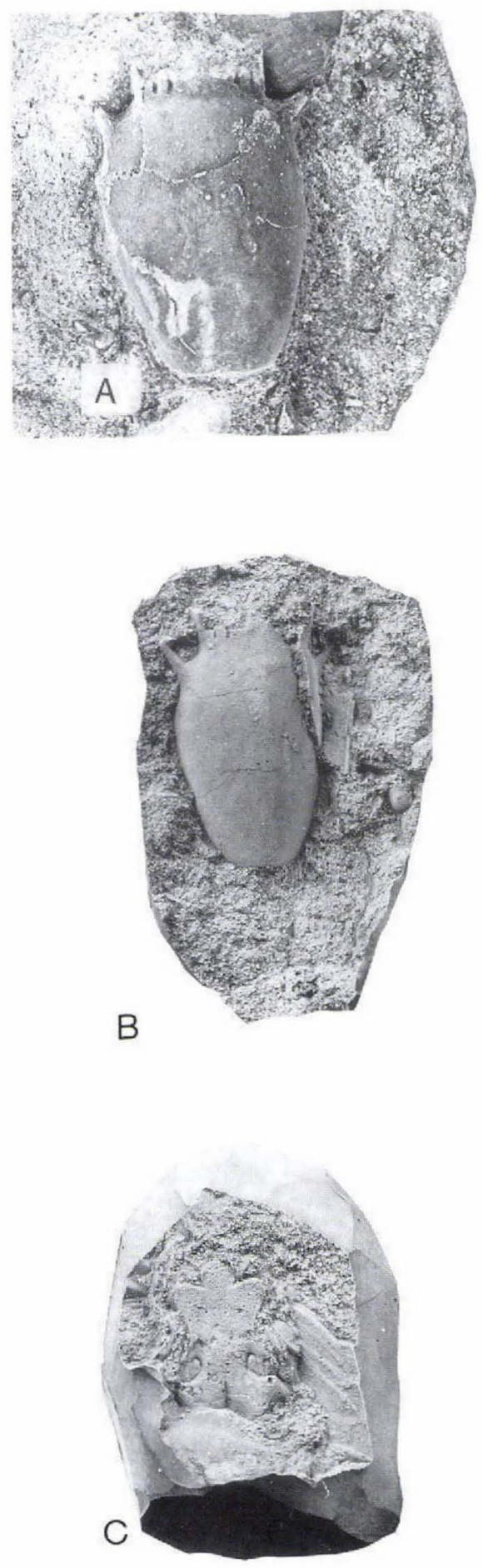
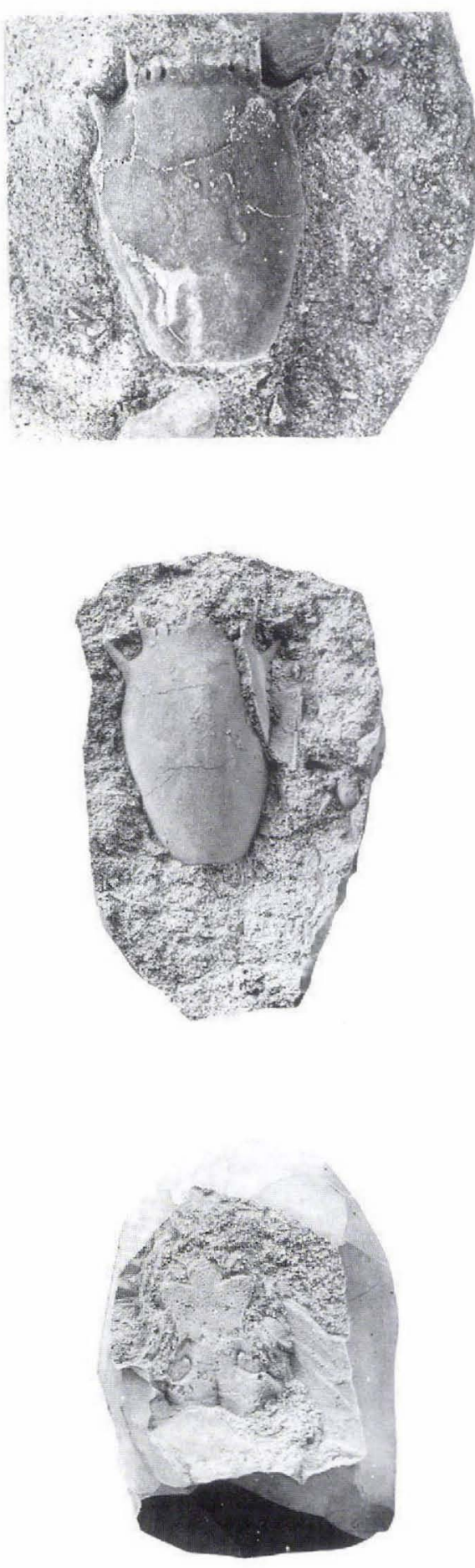

Fig. 18. Laeviranina borealis sp. nov. from the Middle Paleocene at

Qaersutjægerdal. A: holotype, MGUH 21.606, dorsal view of carapace, $\times 1.5$; B: paratype, MGUH 21.607 , dorsal view of silicone rubber cast of the carapace; C: paratype. MGUH 21.608, silicone rubber cast of the anterior part of sternites, $\times 2$. 
the longitudinal curvature is gently convex. The anterior margin is reduced to a short regular curve between the outer orbital and lateral spines. The orbitofrontal margin is straight and occupies about two thirds the carapace width; the dorsal surface of the triangular rostrum is flat to slightly concave, its sides forming a regular curve with a short interorbital spine, or point, at the edge of the inner orbital fissure. Two deep fissures extend nearly the length of the postorbital depression and the spine between is short, flat and rounded apically. The inner fissure is more distant from the median line than it is from the outer orbital spine and the outer fissure is nearer the inner one than to the outer orbital spine. The slender pointed outer orbital spine reaches as far as the rostral tip and is directed straight forward. Occurring about one ninth distant from the front the forward and outwardly directed lateral spine is a little longer than the outer orbital spine and its length is about one fourth the carapace width. The posterolateral margins curve gradually towards the posterior margin and well behind the lateral spine the edge is granulated, the granules persisting as a ridge bounding the posterior margin which is about half the carapace width.

The dorsal surface is covered with numerous rather closely placed minute pores and there are granules within the depressed frontal area and along the anterior half of the lateral margin. The cardiac furrows are smooth and shallow, but distinct. Casts of the inner surface show a pair of curved impressions for the attractor epimeralis muscles, corresponding to the cardiac furrows. Anterior to these are two groups of impressions for the stomach muscles. On the cardiac region three tubercles are set in an inverted triangle and there is a tubercle on each protogastric and a pair on the mesogastric lobes.

The anterior termination of the 4th sternal element is moderately alate, its anterior margin curving forward and outward, and the junction between the 4th and 5th elements is rather elongate, A deep median sternal cleft extends the length of the 5th element.

Of the chelipeds, parts of the ischium, merus, carpus and propodus are preserved; the surface is granulated, with the granules forming short transverse ridges in some areas, especially on the merus, and there is a distal spine on the outer edge of the carpus.

Measurements. Carapace length, including rostrum $21-31 \mathrm{~mm}$. The greatest width excluding lateral spines is about $13-20 \mathrm{~mm}$, or 0.6 of the length; the length of the lateral spines varies between $4-5 \mathrm{~mm}$. The width of the frontal margin ranges between 10.0 and $14 \mathrm{~mm}$ and the posterior margin is a little smaller.
Discussion. Although the generic characters of $L$. borealis, the earliest member of the genus now known, conform in all respects with those laid down by Glaessner (1969), the decision to place borealis in Laeviranina was strongly influenced by Feldmann's (1991) discussion of Laeviranina perarmata Glaessner, 1960; here, Feldmann drew attention to two characters - the relative breadth of the anterior to basal part of the 4th sternal element and the extent of the median sternal cleft - being of possible value in distinguishing Laeviranina from the closely allied genus Raninoides $\mathrm{H}$. Milne Edwards, 1837. The anterior part of sternal element 4 of $L$. borealis is relatively less broad than that of $L$. perarmata, from the Middle Eocene of New Zealand, which has transverse not rounded anterior margins and the sternal median cleft extends to the base of the chelipeds in both $L$. borealis and $L$. perarmata.

In dorsal aspect $L$. borealis has much in common with that of $L$. perarmata, differing little more than in having a stronger postfrontal ridge.

Of European species attributed to Laeviranina, $L$. borealis has much in common with the dorsal aspects of Raninoides glabra (Woodward, 1871), however; the anterior part of the 4th sternal element preserved with recently found specimens of the latter (Collins \& Smith, in press) is noticeably narrower - approaching the posterior breadth of that element - than in L. borealis, and more readily conforms with Feldmann's (1991) requirement for Raninoides.

Section Heterotremata Guinot, 1977

Superfamily Calappoidea de Haan, 1833

Family Calappidae de Haan, 1833

Subfamily Calappinae de Haan, 1833

\section{Genus Camarocarcinus Holland \& Cvancara, 1958}

Type species. Camarocarcinus arnesoni Holland \& Cvancara, 1958 by original designation.

Range. Paleocene.

\section{Camarocarcinus quinquetuberculatus $\mathrm{sp}$.} nov.

Figs 19A-E

1970 ?Necrocarcinus (Camarocarcinus) aff. arnesoni (Holland \& Cvancara, 1958); Rasmussen in Rosenkrantz, p. 443. 

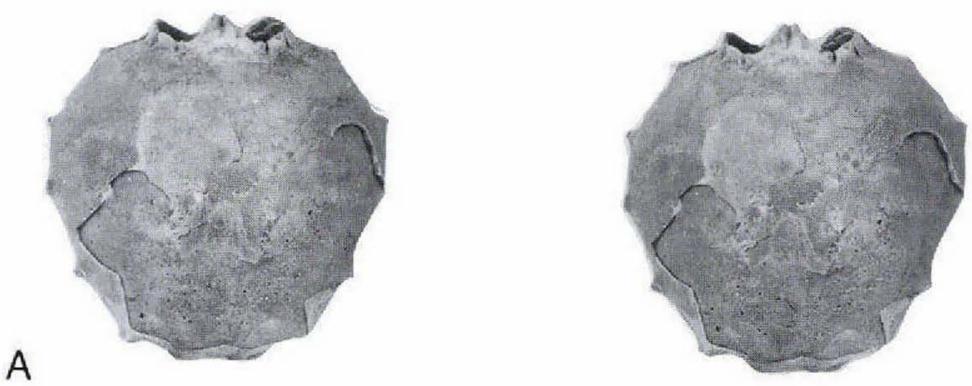

Fig. 19. Camarocarcinus quinquetuberculatus sp. nov, from the Middle Paleocene, $\times 1$. A-D: holotype, MGUH 21.609, from Turritellakløft, A: dorsal view; $B$ : ventral view; $C$ : frontal view. D: lateral view; E: paratype, MGUH 21.610, from Qaersutjægerdal, outer surface of a right-hand chela.
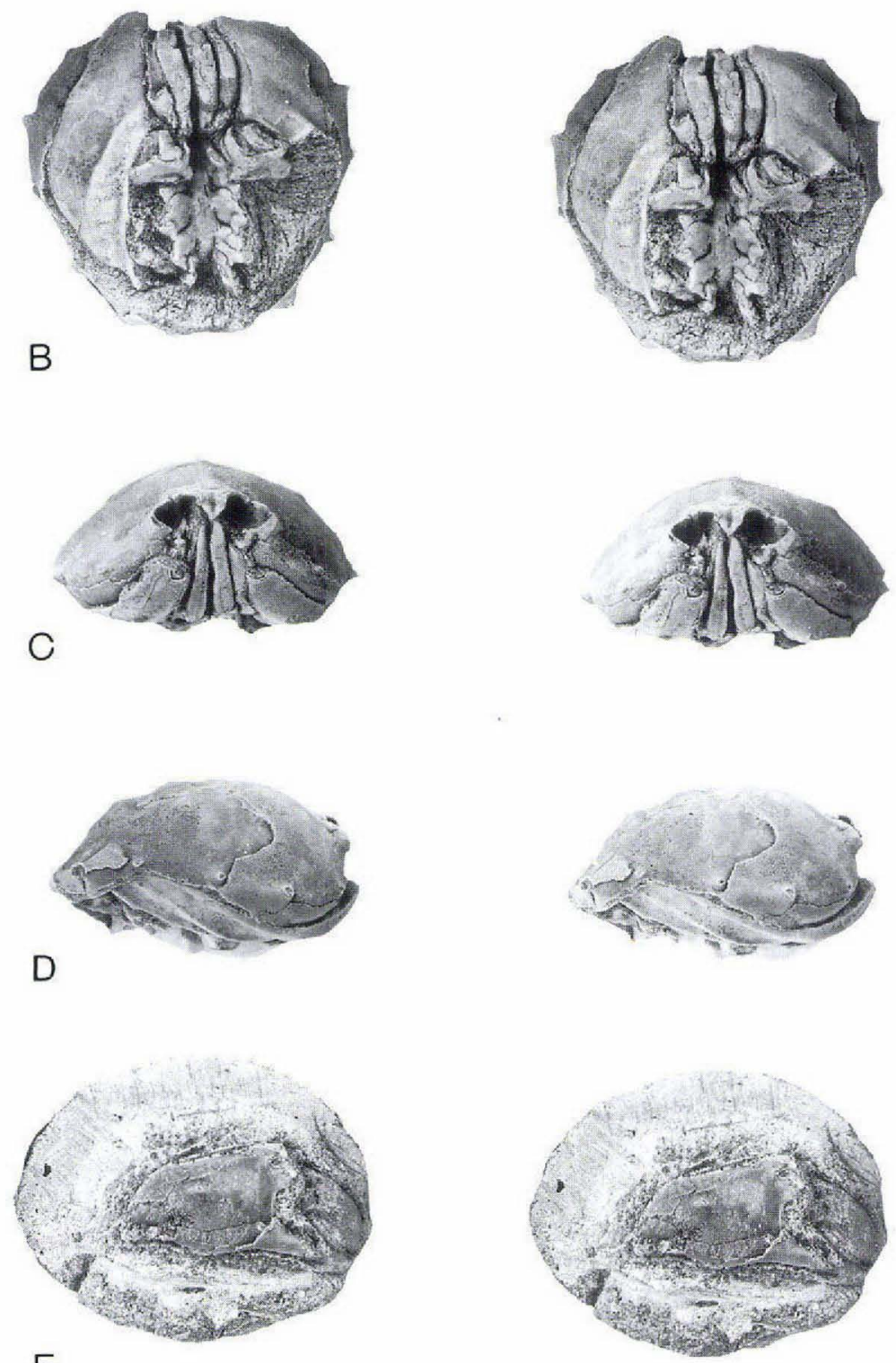

$E$ 
Derivation of name. In reference to the five dorsal tubercles.

Diagnosis. A Camarocarcinus with three median tubercles corresponding to mesogastric, urogastric and cardiac regions, and a less prominent tubercle on each epibranchial lobe. Rostrum depressed, obtusely triangular, deeply sulcate with the high arched edges of the hinder part forming lobes rather than spines. Dorsal surface densely granulated. Cheliped with a long fixed finger sloping obliquely downwards from the propodus.

Material. Thirty-two carapaces and an isolated chela. Holotype, a carapace (MGUH 21.609) from a sandstone concretion found in 1946 in the gorge of Turritellakløft, no doubt originating from the Turritellakløft Member of the Agatdal Formation, central Nûgssuaq. Additional specimens, 3 carapaces from the Agatdal Formation, $553 \mathrm{~m}$ above sea level in the profile of Scaphitesnæsen, in Turritellakløft; 5 carapaces either displaced or from unspecified localities in Turritellakløft; 22 carapaces and 1 chela are from the upper bed of concretions in the sandy Turritellakløft Member of the Agatdal Formation in the great profile of Qaersutjægerdal; 1 juvenile carapace from the Sonja lens of the Agatdal Formation.

Description. The carapace is broadly ovate in outline; the width almost equals the length and widest about one third distant from the front. It is rather strongly rounded both longitudinally and transversely; in side view the highest point occurs about one third distant from the front and the descent from the cardiac region to the posterior margin is steeply inclined. The anterolateral margin is short and more or less evenly rounded with a short triangular spine on a level with the upper orbital margin, followed in some instances by a row of four or five irregular-sized granules. The posterolateral margin is gently rounded with four prominent radiating spines of which the hindermost is the longest - reaching up to one tenth of the carapace width - and most boldly curved. The distance between the second and third spines is slightly greater than between the first and second and third and fourth. Acutely rounded posterior angles lead into the gently concave posterior margin which is a little narrower than the orbitofrontal margin and bounded by a narrow rim.

Deep, broadly ovate orbits are directed a little upwards and in front view are inclined downward and outward at an angle of $c .52^{\circ}$; they take up the outer halves of the orbitofrontal margin which occupies about four fifths of the carapace width. The rostrum is deeply sulcate, obtusely triangular and abruptly downturned in front where it extends a little beyond the orbital margin; behind, the prominently arched sides form a projection, but not a spine as in C. arnesoni. Two notches pierce the raised upper orbital margin which becomes somewhat thickened at the rounded lower orbital angle. On the dorsal surface three large tubercles or elevations occupy the mesogastric, urogastric and cardiac regions; that on the mesogastric is low and broadly rounded, the urogastric one is higher and more or less pointed, while that on the cardiac region is much the same height but more elongate and often has a small elevation posteriorly. On each epibranchial lobe a low tubercle forms a transverse line with the mesogastric tubercle, but on some of the larger specimens these tubercles are less distinct. From a small pit on either side of the midline the cervical furrow extends forwards and outwards as an indefinite line of pits set at an angle of about $40^{\circ}$ to the midline; at the outer end of each line is a large, deep indentation ringed with fine pits followed by a curve of two or three rows of irregularly sized pits which, tapering to a single row, reaches the margin just forward of the second lateral spine. A little forwards and median to the abovementioned indentation is a small pit containing a single granule. On either side of the urogastric lobe is a large circular indentation which on subsurface shell-layers is seen as a group of individual pits. Behind this indentation a shallow depression with traces of epimeral attractor muscle scars separates the urocardiac from the branchial regions. A hatchured mass of pits, tapering to a single row curves outwards from the anterior part of the cardiac region to the margin between the second and third spines.

The dorsal surface of the remarkably thick shell is densely covered with granules of two, relatively speaking, quite distinct diameters, the smaller maintaining a constant ratio irrespective of the actual size of the larger. In general those on and behind the rostrum, covering the tubercles and towards the posterior margin are the smallest and more densely packed. On larger specimens a few crateriform pits are interspersed among the open pits marking the cervical furrow and there is a scattering on the anterolateral part of the protogastric lobes which almost ousts the granular ornament. These pits, which do not appear to penetrate the shell surface, are fairly constant in size and about equal in diameter to the largest granules. On inner shell-layers cratered pits take the place of the granules. Internal moulds show a weak tubercle on each protogastric lobe and a scattering of fine granules behind the orbits. Hatchured pits behind the mesogastric lobe mark the possible site of either the posterior gastric or internal mandible adductor muscles. 
The pterygostomial processes are trapezoidal in outline; a bluntly rounded sigmoidal ridge curves along the lateral margin and a second, narrower, sharper almost median ridge runs back almost parallel to the lateral one to the posterior angle of the buccal margin. The area between the ridges is broadly concave, as is the somewhat narrower area between the median ridge and buccal margin. The third maxillipeds completely cover the buccal cavity. The long endognath has a slender ischium and a strongly curved very long and narrow merus reaching the underside of the rostrum. The somewhat narrower exognath is a little longer than the ischium of the endognath.

The sternites are partly fused to a rather narrow sternum forming a median furrow, on each side of which is a lateral flange divided by furrows or fissures into four or five sternites.

Associated, though more or less damaged chelipeds are preserved with several carapaces. The shell is very thick and there is considerable difference between the stout chela seen on impressions of the outer surface and the apparently slender ones preserved only as casts of the inner surface. The left and right chelipeds are similar in size and form; the merus is short and has a tumid outer and flattened inner surface apparently with neither ridge nor spine. In side view the almost triangular carpus is very short and tumid, it has a lateral spine and another, distal, on the upper margin. The rather long, slender propodus increases in height distally, the upper margin is sharp with, perhaps, four tubercles and three or four line the lower margin. There is a longitudinal ridge on the outer surface with three or four spines and another, transverse, ridge behind the upper part of the distal margin. The inner surface is almost flat. The fixed finger is curved a little outwards and strongly downwards and a row of rounded teeth lines the opposing margin. The outer surface is closely and finely granulated.

A specimen from Qaersutjægerdal with associated chelipeds has a carapace length of $36 \mathrm{~mm}$, the length of the merus is $14.0 \mathrm{~mm}$; carpus, $c .9 .0 \mathrm{~mm}$; propodus $c$. $22.0 \mathrm{~mm}$; dactylus, c. $13.0 \mathrm{~mm}$, and the height of the segments from merus to propodus increases from about $7.0 \mathrm{~mm}$ to $9.0 \mathrm{~mm}$.

Discussion. Dorsal tubercles or nodes are to some degree present on young forms of both the other members of the genus, $C$. arnesoni Holland \& Cvancara, Paleocene Cannonball Formation of North Dakota and $C$. obtusus Jakobsen \& Collins, 1979 from the Selandian of Sjælland, Denmark, but apart from that on the cardiac region which remains fairly obvious, the others are for the most part absorbed as growth advances. Thus, the prominent median gastric and epibranchial tubercles persisting through all stages of growth readily distinguish the new species. The orbits are as open as are those of $C$. arnesoni, but rather more upwardly directed; and their inclination to the midline is $52^{\circ} \mathrm{com}$ pared to $45^{\circ}$ obtained in $C$. arnesoni. The orbits of $C$. obtusus, on the other hand, are considerably less open and inclined at an angle of $68^{\circ}$. C. quinquetuberculatus lacks the spine at the base of the rostrum present on the other species, but unlike either of them has a stronger spine preceding the row of granules lining the anterolateral margin. The numerous crateriform pits crowding the surface of $C$. arnesoni, interpreted by Holland \& Cvancara $(1958,1959)$ to have been setiferous, and seen also on $C$. obtusus are much less in evidence on $C$. quinquetuberculatus.

\section{Genus Cristella gen. nov.}

Derivation of name. A little keel - in reference to the median crest.

Type species. Cristella hastata sp. nov.

Diagnosis. Carapace subhexagonal with a narrow pointed rostrum; three spines on the upper orbital margin, the outermost stout and in line with the first of four anterolateral spines of which the fourth, at the lateral angle, is much attenuated. The dorsal surface is transversely arched with a median row of compressed spines forming a crest and, on either side, a longitudinal ridge bearing three spines.

\section{Cristella hastata sp. nov.}

Fig. 20A, B

Derivation of name. Hasta (Latin) a lance, with reference to the lateral spines.

Diagnosis. As for genus.

Material. The holotype and only known specimen is an almost complete carapace in a small, calcareous concretion from black shales of the Kangilia Formation on the south side of Turritellakløft (opposite west end of the great profile) (MGUH 21.611).

Description. The carapace is subhexagonal in outline, the length and breadth almost equal if the rostrum and lateral spines are excluded, and transversely steeply 
Fig. 20. Cristella hastata sp. nov., hoLower Paleocene at Turritellakløft, A: dorsal view; $B$ : frontal view, $\times$ 1.5 . lotype, MGUH 21.611, from the late
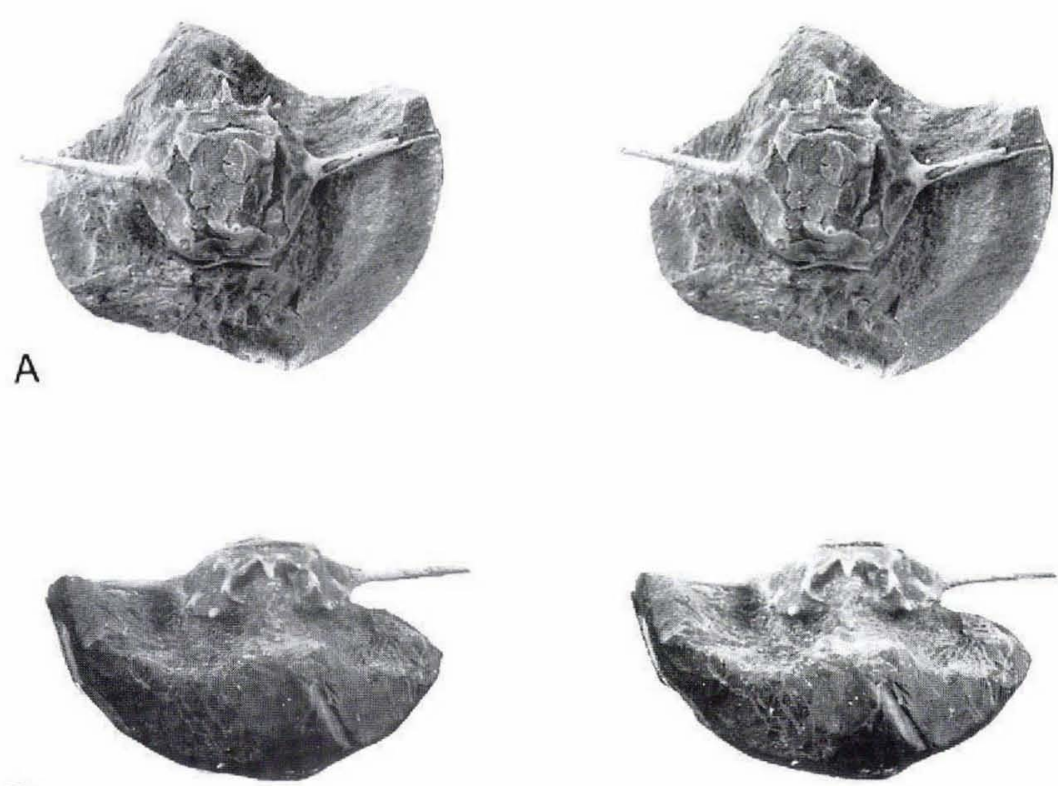

B

arched, much like a gambrel-roof in section. The orbitofrontal margin is straight and occupies a little more than half the carapace width measured at the base of the lateral spines. The orbital and antennal cavities are fairly shallow, ovate and divided by a low septum, the rather long, slender rostrum tapers gradually to a point; it is triangular in section with the dorsal surface slightly concave and weakly depressed between bluntly pointed inner orbital spines. There is a smaller spine near the middle of the thinly raised orbital margin and a stout triangular outer orbital spine which has its outer margin sweeping backwards and outwards towards the third lateral spine. Of the four spines on the weakly rounded anterolateral margin the first occurs almost on a level with and a little below the outer orbital spine and gives a false impression of the width of the orbitofrontal margin. The second, much reduced almost granular spine is set equidistant between the first and stout, triangular third spine. The fourth spine at the lateral angle is slender and circular in section; projecting almost at right angles to the anterolateral margin it curves a little forwards and backwards, its length exceeding three fourths of the carapace width. The posterolateral margin is almost straight and a little longer than the anterolateral margin; it leads by fairly acute posterior angles to the slightly concave posterior margin which is about as wide as the front and bounded by a raised rim.

Shortly behind the front a low transverse ridge extends across the carapace to a stout spine on the protogastric lobe, then turns sharply forward to terminate between the middle and outer orbital spines. The prom- inent median ridge is composed of a large spine, triangular in outline, at the base of the anterior mesogastric process followed on the rhomboidal mesogastric lobe by a high, much compressed spine with a rounded summit. The outlines of these two spines are repeated in miniature on the urogastric lobe and all are united at their base to form a continuous carina. The cardiac region is lingulate and has two rounded spines, the first, much the larger, tops a low rounded 'ridge' which connects with the foremost of the metabranchial spines. There is a large forwardly directed spine on the hepatic region and a somewhat curving ridge on either side of the median ridge unites the bases of three spines; the first, on the epibranchial lobe, is small, laterally directed and also united by a similar ridge to the lateral spine. the second forms the first of the metabranchial spines while the third spine, set a little laterally and opposite the basal cardiac spine, is vaguely joined by an oblique 'ridge' to the marginal base of the lateral spine. A smaller protogastric tubercle occurs between the outer angle of the mesogastric lobe and the hepatic spine. The cervical furrow, interrupted at the midline by the median carina, is straight at the base of the mesogastric lobe then runs sharply forwards and outwards to that lobe's lateral angle where, turning out, it loops round the bases of the protogastric and hepatic spines to reach the lateral margin well forward of the lateral spine. Very faint, crescentic epimeral adductor muscle scars parallel the median course of the cervical furrow and unite, behind, with the branchiocardiac furrow which defines a narfow mesobranchial lobe before curving broadly for- 
ward and outward to become obsolete at the base of the lateral spine.

A few minute granules are scattered over the otherwise smooth dorsal surface.

Measurements. The length of the carapace excluding rostrum is $10.2 \mathrm{~mm}$; length of rostrum, $2.2 \mathrm{~mm}$; the carapace width excluding lateral spines is $11.9 \mathrm{~mm}$ and each lateral spine is more than $9.0 \mathrm{~mm}$ in length.

Discussion. Cristella appears to have a close affinity to, and could well have been derived from Necrocarcinus, particularly the Maastrichtian $N$. pierrensis (Rathbun, 1917). In the latter species the lateral spines are moderately developed, typical of the genus as a whole, the rostrum is short and bifurcate, and the upper orbital margin is pierced by notches and rather more sinuous than in Cristella. Both species have in common, however, the transverse row of gastric spines and the outermost one on $N$. pierrensis has a spinule between it and the upper orbital margin foreshadowing the inturned 'ridge' on Cristella. In transverse section $N$. pierrensis is more evenly curved, and the hepatic and epibranchial lobes more tumid; the lateral branchial spines are reasonably well developed in $N$. pierrensis, but anteriorly they commence with a spine on the mesobranchial rather than the epibranchial lobe as in Cristella; a low ridge connecting cardiac and metabranchial spines is present in some small carapaces.

Rathbun (1917) originally placed 'pierrensis' in Campylostoma, a monotypic Lower Eocene genus. The structure of the frontal region, the vaguely tricarinate dorsal surface and arrangement of the - albeit suppressed - tubercles strongly suggests Campylostoma to have been derived from Necrocarcinus through $N$. pierrensis. Campylostoma, however, differs largely in having much produced lateral spines (Collins, 1961) which are such a prominent feature of Cristella, although in the latter they are positioned more anteriorly. There is also a similarity, to some extent, in the dorsal carination and tuberculation, but whereas the front of Campylostoma retains the bifurcate, deeply sulcate rostrum of Necrocarcinus, Cristella has a slender, elongate rostrum. It would seem that where Campylostoma and Cristella may have a common ancestry in Necrocarcinus they have developed independently along separate lines.
Superfamily Xanthoidea Dana, 1851

Family Xanthidae Dana, 1851

\section{Genus Xanthilites Bell, 1858}

Type species. Xanthilites bowerbanki Bell, 1858 by monotypy.

Range. Paleocene to Middle Eocene.

\section{Xanthilites verrucoides sp. nov. Fig. 21A-C}

Derivation of name. With reference to the wart-like ornament.

Diagnosis. A Xanthilites with four hexagonal spines, the largest at the lateral angle; the regions are tumid with large conical tubercles of which those on the cardiac region are fused into a transverse elevation.

Material. Holotype MGUH 21.612 in a limonitic concretion from the upper bed of concretions in the sandy Turritellakløft Member of the Agatdal Formation in the great profile at Qaersutjægerdal in central Nûgssuaq. Additional specimens, 2 specimens in concretions from the type locality.

Description. The carapace is hexagonal in outline, about one third wider than long and moderately curved in longitudinal and transverse sections. The front is incompletely preserved, it takes up about half of the orbitofrontal width which occupies rather less than half the carapace width; it projects a little beyond the outer orbital spine and apparently had four spines. The raised upper orbital margin has two shallow notches, possibly separated by a spine and there is a small outer orbital spine. The anterolateral margin is convex with three more or less equal sized slightly upturned triangular teeth and a rather more robust one at the lateral angle. The nearly straight posterolateral margins converge sharply to the posterior margin which is a little less than the orbitofrontal width, almost straight and bounded by a low rim. The anterior mesogastric process tapers narrowly to a point at the base of the front where it is separated by fine grooves from small epigastric lobes which on the shell surface lead back to and are confluent with a robust rounded tubercle on each protogastric lobe although they are more or less isolated on internal casts. There is a similar sized median tubercle 
Fig. 21. Xanthilites verrucoides $\mathrm{sp}$. nov. from the Middle Paleocene at Qaersutjægerdal, $\times 1.5$. A. C: holotype, MGUH 21.612; A: dorsal view; C: silicone rubber cast from the external mould showing finer details of ornament; B: paratype, MGUH 21.613, dorsal view.
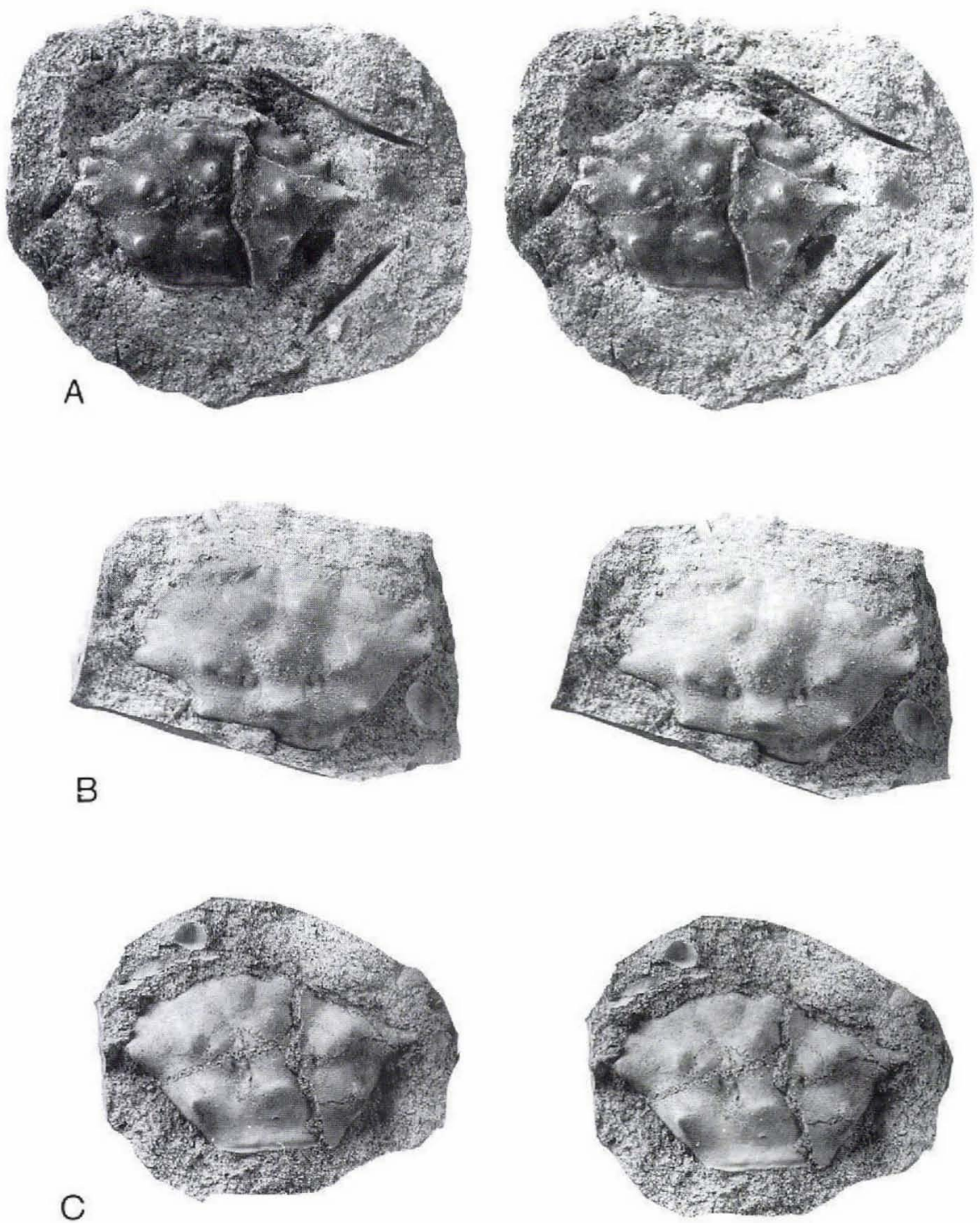

on the pentagonal mesogastric lobe, a large tubercle on each epibranchial lobe about level with the lateral spines, a small one close behind it on the mesobranchial lobe, and another large tubercle on each metabranchial lobe. At the widest part of the lingulate cardiac region a transverse ridge is formed from the fusion of the paired tubercles normally occurring, their summits appearing as granules. The hepatic region is depressed but weakly tumid. The cervical furrow is wide and shallow from the hinder angles of the mesogastric lobe to the lateral margins. On the posterior lateral slope of the mesogastric lobe is an oblique row of small granules which may indicate a muscular attachment and a double depression on either side of the confluent uro-cardiac region corresponds to the epimeral adductor muscle at- tachment. A few widely scattered granules occur on the otherwise smooth dorsal surface.

The length of the holotype carapace is about $16.5 \mathrm{~mm}$ and the width, including the lateral spine, is about 25.0 $\mathrm{mm}$.

Discussion. In general outline the carapace of $X$. verrucoides approximates that of $X$. gerthi Glaessner, 1930, ?Paleocene of Argentina, but the latter differs in having the first anterolateral spine more or less in line with the outer orbital spine and relatively narrower orbits; there is a marked difference, however, in the distribution of tubercles which on $X$. gerthi are altogether smaller, those on the protogastric lobes in particular are much reduced, isolated from the epigastrics, none is devel- 

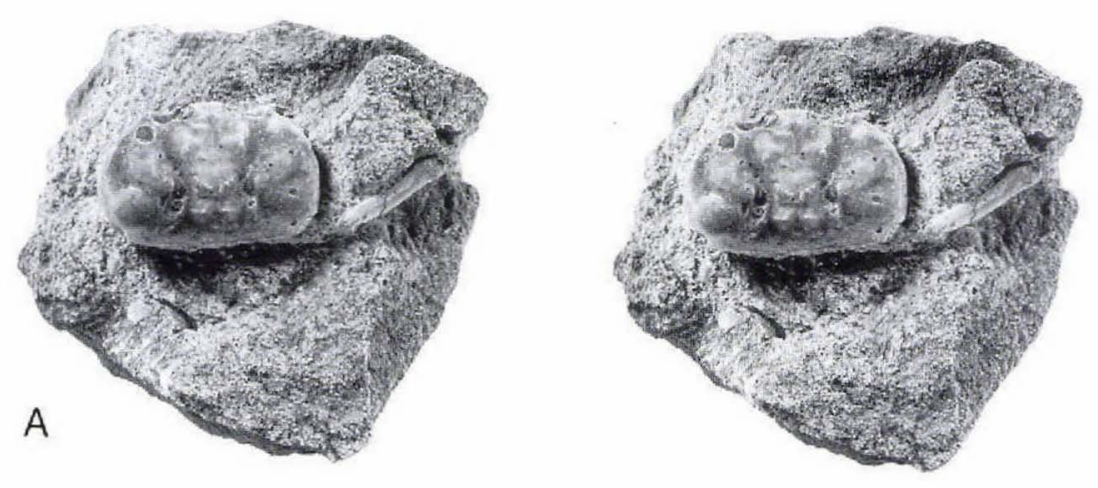

Fig. 22. Pinnixa (Palaeopinnixa) nodosa sp. nov., holotype, MGUH 21.614, from the Middle Paleocene at Qaersutjægerdal. A: dorsal view; $\mathrm{B}$ : frontal view, $\times 1.5$.
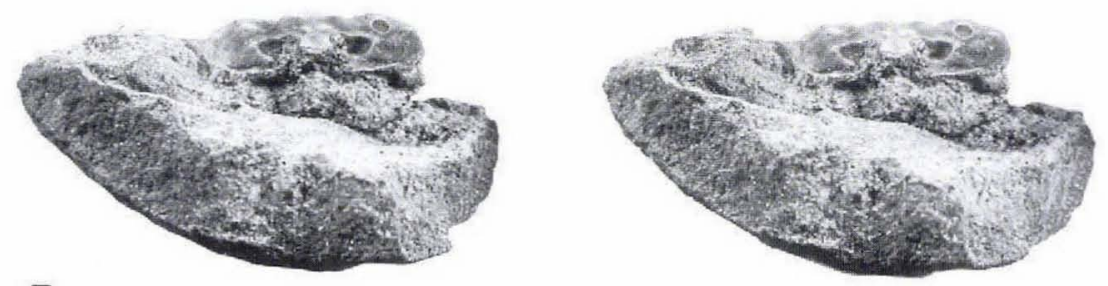

B

oped on the mesobranchial lobe and that on the epibranchial is placed nearer the lateral margin. Only three lateral spines are present on the Lower Eocene $X$. alabamensis Rathbun, 1935, but by and large there is a close agreement in ornamentation, though in $X$. alabamensis the entire surface of the proto- and mesogastric lobes are swollen as if having absorbed the tubercle and the tubercles on the meso- and metabranchial lobes are larger.

Section Thoracotremata Guinot, 1977

Superfamily Pinnotheroidea de Haan, 1833 Family Pinnotheridae de Haan, 1833

\section{Genus Pinnixa White, 1846}

Type species. Pinnotheres cylindricum Say, 1818, by monotypy.

Range. Eocene to Recent.

\section{Subgenus Palaeopinnixa Via, 1966}

Type species. Pinnixa eocenica Rathbun, 1926, by original designation.

Range. Paleocene Upper Danian to ?Recent.
Pinnixa (Palaeopinnixa) nodosa sp. nov. Figs. 22A-B

Derivation of name. Referring to the nodose dorsal surface of the carapace as seen on casts of its inner side.

Diagnosis. Carapace with a weak anterolateral spine and prominently elevated regions. The gastrohepatic furrow is short, deep and broad.

Material. Eight more or less complete carapaces. Holotype, an internal mould of a carapace retaining part of a walking limb, in a sandstone concretion from the Turritellakløft Member of the Agatdal Formation of Qaersutjægerdal in the central area of Nûgssuaq, MGUH 21.614. Additional specimens, a fragmentary carapace from the Gilbertina sandstone lens in the Turritellakløft Member at Turritellakløft, central Nûgssuaq; six carapaces from the Sonja lens of the Agatdal Formation in the south wall of Agatkløften, central Nûgssuaq.

Description. Carapace length about two thirds the width, moderately rounded longitudinally and almost flat in transverse section. Broadly ovate orbits occupy the outer thirds of the orbitofrontal margin which reaches about half the carapace width. The almost straight 
front has a shallow median depression, its concave sides curve with no evidence of a notch into the finely beaded upper orbital margin, terminating in an obscure outer spine. The lower orbital margin extends beyond the upper and bears a spine near the inner angle. The anterolateral margins are short and well rounded, there is a small, rather upstanding spine immediately behind the cervical furrow. Finely ridged postolateral margins, moderately rounded in juvenile forms, become almost straight as growth advances and lead by shallow coxigeal incisions to a very wide, nearly straight posterior margin. The sides are inclined a little inwards. The cervical furrow runs from a weak marginal notch about one third distant from the front in a broad shallow groove round the hepatic region to join the hepatic furrow, then becomes very faint - almost indiscernible on the shell surface along the base of the mesogastric about mid-carapace length. Short, deep hepatic furrows lead from near the outer orbital angles almost straight back, curving inwards at the union with the cervical furrow they continue at this angle to the base of the urogastric lobe. The equally prominent branchiocardiac furrow curves broadly between the confluent tumid epiand mesobranchial lobes and laterally tumid metabranchial lobe; at the anterior border of the cardiac region it divides, one furrow delimiting the cardiac region, the other sweeping round to the coxigeal incisions. Shallow furrows delineate the protogastric lobes from a very small subtriangular mesogastric lobe and the narrow anterior process extends to rounded epigastric lobes level with the upper orbital margin. Rounded hepatic regions are slightly tumid. A slender median extension unites the cardiac region with an otherwise separated large, sub-ovate urogastric lobe. The cardiac region is lingulate and on either side an elongate node lies between it and the meta-branchial lobe.

The median course of the cervical furrows, in particular, and some of the nodes are absorbed by the shell thickness. The outer shell surface retained on a juvenile specimen from Agatkløft has fine granules on the gastric lobes, rather larger ones on the hepatic and branchial lobes and a few lining the anterolateral margin are particularly noticeable. There is a smooth depressed area behind the upper orbital margins. Internal casts reveal three tubercles on the cardiac region. On each protogastric lobe a curving ridge reaches almost to the outer orbital angle; traces of this ridge are seen on the juveniles and it becomes considerably more prominent as growth advances. Along the posterior edge of the urogastric lobe is a V-shaped muscle scar; a pit on either side of the midline and rugose adductor epimeralis muscle scars mark the nodes abutting the cardiac region.

The sternites as a whole are much rounded longitudi- nally; the fifth pair are large and subtriangular; the sixth-eighth pairs are trapezoidal and decrease in size posteriorly, the eighth pair being about half the size of the sixth. The deep abdominal trough extends nearly the length of the fifth sternites and becomes broadly triangular from the seventh sternites posteriorly.

The carapaces range from $4.5 \mathrm{~mm}$ to $15.0 \mathrm{~mm}$ in width and from $3.4 \mathrm{~mm}$ to $9.6 \mathrm{~mm}$ in length and while the longitudinal curvature of the juveniles is flatter the regions and coarser ornament, as evidenced by internal casts, are clearly defined.

Discussion. Apart from a small lateral spine and a slight thickening of the orbital margin the new species has the essential characters of Palaeopinnixa and can, for the time being at least, be included in that subgenus.

Remnants of the nodular ornament of $P$. (P.) nodosa are seen on the Lower or Middle Eocene $P$. (P.) perornata Collins \& Morris, 1976, on which the protogastric 'ridge' is reduced to two nodes (on this species two nodes are also present on the hepatic regions). The three cardiac tubercles persist, as does the node on either side of that region. Vestigial portions of the cervical furrow remain on $P$. (P.) perornata (as they do on some Recent Pinnixa spp.) although the major furrows are much weaker. $P$. (P.) nodosa has rather larger orbits than $P$. ( $P$.) perornata and in this respect is closer to $P$. (P.) eocenica Rathbun, 1926, which while having prominent hepatic, cardiac and metabranchial furrows, lacks any evidence of the cervical furrow. $P$. (P.) nodosa may be further distinguished from other members of the subgenus in having more clearly defined mesogastric and urogastric lobes.

$P$. (P.) nodosa represents the earliest known member of the subgenus. From its appearance in western Greenland it would appear to have spread rapidly southwestwards and southerly, $P$. (P.) eocenica reaching Washington State, and $P$. $(P$.) perornata Barbados by the Upper Eocene. Via (1966) described $P$. (P.) mytilicola from the Miocene of Barcelona and considered the Recent Pinnixa minuta Rathbun, 1901 formed a living representative of the subgenus.

Superfamily Ocypodoidea Rafinesque, 1815

Family Retroplumidae Gill, 1894

\section{Genus Costacopluma Collins \& Morris, 1975}

Type species. Costacopluma concava Collins \& Morris, 1975 by original designation.

Range. Cretaceous to Paleocene. 
Costacopluma binodosa sp. nov. Fig. 23A-B

Derivation of name. Alluding to the distinct rounded nodes at the posterior angles.

Diagnosis. A Costacopluma with the carapace only a little wider than long and almost straight lateral margins slightly convergent anteriorly. Nodes on either side of the cardiac region are nearly isolated from that region and there is a prominent node above each posterior angle. The elevated areas are prominently granulated and the depressions finely pitted.

Material. A unique carapace, MGUH 21.615, from an Upper Campanian sandy concretion from the black shales in Brudkløft at Ikorfat on the north coast of Nûgssuaq.

The specimen is possibly that of a female and shows the dorsal surface, except the crushed anterior margin and protogastric lobes, and much of the ventral surface.

Description. Carapace almost rectangular a little wider than long and not much arched transversely. The lateral margins diverge to well rounded lateral angles set about three fourths distant from the front and short posterolateral margins lead by wide, shallow incisions for the fifth coxae to a narrow nearly straight posterior margin which occupies about half the carapace width. The posterior margin and incisions are bounded by a rim of fine granules. The lateral edge is raised and narrowly rounded as far as the posterior transverse ridge and coarsely granulated; the sides, almost vertically inclined anteriorly, become slightly splayed out towards the posterolateral angles. The cervical furrow is acutely V-shaped where it crosses the midline about mid-carapace length, after which its course is obscure; at the lateral edge it runs steeply down and, becoming very shallow passes round the somewhat overhanging hepatic region and continues to the buccal frame. The mesogastric lobe is flatly tumid, subpyriform and barely separated from the small depressed urogastric lobe. The cardiac region is pentagonal, but its outline is distorted by its partial union to tumid nodes laterally and behind to close proximity to the intestinal region.

The foremost of the transverse ridges appears to be interrupted by the anterior mesogastric process. The rather broad second, or epi-mesobranchial ridge is forwardly inclined at about $51^{\circ}$ to the longitudinal axis. The third, metabranchial, ridge occurs about midway from the second ridge to the posterior margin, it is directed forwards in a slightly sinuous curve and is continued across the carapace by the tumid anterior portion of the cardiac region. From the inner angle of this ridge a short ridge (more strongly developed on the righthand side) runs back to the node at the cardiac angle.

The triangular pterygostomian process is inflected almost at right angles to the carapace margin and is finely granulated along the pleural margin. The buccal cavity is about as broad as long; its margins are covered by the exognaths of the third maxillipeds. The exognath is fusiform and reaches to about the middle of the meropodite, its width is about one fourth its length. Of the endognath, the ischiopodite is about twice as long as wide, subreniform in outline and flattened; the meropo-

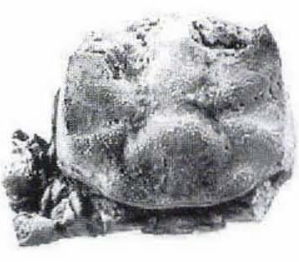

A

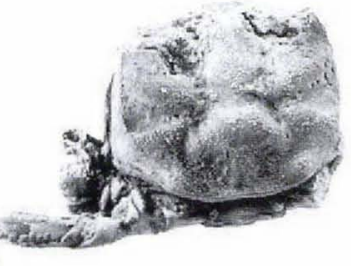

B

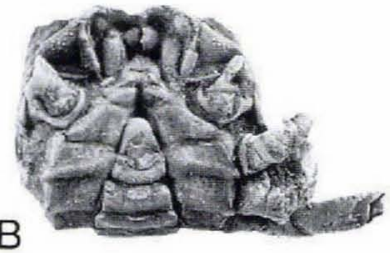

Fig. 23. Costacopluma binodosa $\mathrm{sp}$. nov., holotype, MGUH 21.615, from the Upper Campanian at Ikorfat. A: dorsal view; C: frontal view, $\times 1.5$. 
Fig. 24. Stratigraphical distribution of decapod crustaceans from Nûgssuaq, West Greenland.

\begin{tabular}{|c|c|c|c|c|c|c|}
\hline CHRONOSTRATIGRAPHY & 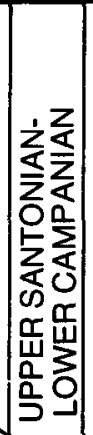 & 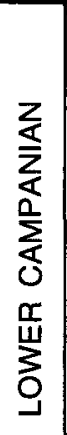 & 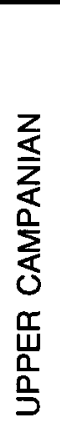 & 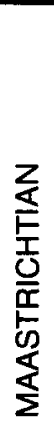 & 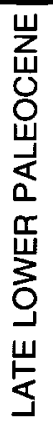 & 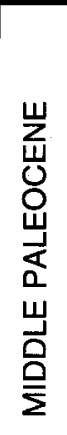 \\
\hline Mecochirus rostratus sp. nov. & & & $\bullet$ & $\bullet$ & & \\
\hline Linuparus (Podocrates) spinosus sp. nov. & & & $\bullet$ & & & \\
\hline Galathea cf. G. strigifera Fischer-Benzon & & & & & & $\bullet$ \\
\hline Dromiopsis granulata sp. nov. & & & & $\bullet$ & & \\
\hline Eohomola adelphina gen. et sp. nov. & & & - & $\bullet$ & & \\
\hline Cristella hastata gen. et sp. nov. & & & & & - & \\
\hline Camarocarcinus quinquetuberculatus sp. nov. & & & & & & - \\
\hline Hemioon eysunesensis sp. nov. & & & $\bullet$ & & & \\
\hline Lyreidus succedanus sp. nov. & & $\bullet$ & $\bullet$ & $\bullet$ & & \\
\hline Lyreidus rosenkrantzi sp. nov. & & & & $\bullet$ & & \\
\hline Lyreidus bispinulatus sp. nov. & & & & & & $\bullet$ \\
\hline Notopocorystes (C.) paututensis sp. nov. & - & & & & & \\
\hline Laeviranina borealis sp. nov. & & & & & & $\bullet$ \\
\hline Xanthilites verrucoides sp. nov. & & & & & & - \\
\hline Costacopluma binodosa sp. nov. & & & $\bullet$ & & & \\
\hline Pinnixa (P.) nodosa sp. nov. & & & & & & • \\
\hline
\end{tabular}

dite is subovate and the three terminal segments of the palp are of equal length. Strong, subcircular mandibles occupy the median part of the buccal cavity.

The first abdominal sternites are triangular and depressed, the second are rectangular, strongly nodose with ridges running to attenuated outer angles. The subtriangular third sternites rise steeply from the second become flattened posteriorly and are separated by a shallow furrow from the large trapezoidal fourth sternites on which a broadly rounded ridge borders the chelipeds. The fifth-eighth sternites are subrectangular, on each the posterior edge is ridged and each has the outer margin overlapped by an extension of the one preceding. The abdomen is folded against a deep median trough, it occupies half the sternal width at its proximal part and gradually decreases to less than a third at the sixth somite. The subtriangular telson reaches almost to the fourth sternites. The width diminishes very gradually without any lateral expansion and it is only a little wider than in the males of $C$. concava Collins \& Morris (1975, pl. 97). The present specimen, therefore, may be a young female, similar to Archaeo- 
pus antennatus Rathbun (1908, pl. 48, fig. 3), but in the latter the median trough is considerably shallower and the telson extends a short distance between the fourth sternites.

The bases of the chelipeds and parts of the first-third pereiopods are preserved; the cheliped bases are slightly stouter than those of the pereiopods and a fragment of the merus of the fourth pereiopod shows a smooth, flattened inner side and a granulated arched outer side.

The carapace has a width of $16.5 \mathrm{~mm}$ and rather exceeds $14.0 \mathrm{~mm}$ in length.

Discussion. Costacopluma binodosa differs from $C$. concava and C. senegalensis (Remy, 1960) in having a more rectangular outline and a somewhat flattened median transverse ridge. The node on either side of the cardiac region, which Collins \& Morris (1975, p. 826) referred to as the outer pair of four tubercles on the cardiac region, are more isolated in $C$. binodosa. In addition the elongated tubercle close to the posterior angle, moderately developed in $C$. concava and apparently subdued in $C$. senegalensis, is much enlarged in $C$. binodosa. On the underside, the ridges on the fifth and sixth sternites of $C$. binodosa are obliquely rather than transversely directed as on $C$. concava.

The genus Costacopluma was erected by Collins \& Morris (1975) on C. concava which ranges from the Coniacian to Maastrichtian of Nigeria; a Paleocene member of the genus was recognised in $C$. senegalensis (Remy) from Senegal. The presence of $C$. binodosa in the Upper Campanian of West Greenland indicates a very rapid northern migration of the genus during Upper Cretaceous, while a continuing favourable environment remained in the African province.

\section{Summary}

The geologically earliest crab in the present collection is Notopocorystes (Cretacoranina) paututensis preserved on slabs of red-burned clay considered to be of Upper Santonian or lowermost Campanian in age (Fig. 24). The raninid species recorded by Rosenkrantz (1970, p. 425) from the uppermost Lower Campanian deposits in Turritellakløft (Agatdal region) is described herein as Lyreidus succedanus and is the earliest known member of the genus the northerly range of which is also extended. It is a fairly common species in the lower Campanian and ranges into the Maastrichtian, where it occurs with $L$. rosenkrantzi.

The Upper Campanian of the region has yielded four other species of crabs; of these a single carapace of Costacopluma binodosa considerably extends the northerly range of the genus. Eohomola adelphina has a well developed bifid rostrum and shares this and other characters with $E$. dispar (Roberts) from the Campanian of North America. Eohomola adelphina also occurs in the Maastrichtian and clearly foreshadows some members of the Recent Homola. Hemioon eysunesensis, which apparently descended from $H$. elongatum (H. Milne Edwards), appears to have been another fairly common member of the bottom fauna; the well preserved specimens provide an insight to the structure of the underside and limbs, knowledge of which is scant among other members of the genus. Linuparus spinosus and Mecochirus rostratus are each represented by only one specimen. Over 2000 specimens of $M$. rostratus, however, are known from the Maastrichtian where the species occurs with the raninids Lyreidus rosenkrantzi and L. succedanus; Dromiopsis granulata would appear to be related to $D$. rugosus (Schlotheim, 1820).

Numerous callianassid remains included in the crustacean collection from the Cretaceous of West Greenland are not included within the scope of this work.

Late Lower Paleocene deposits have yielded only one crab bearing nodule. It contains Cristella hastata, seemingly an offshoot of the Campanian Necrocarcinus pierrensis (Rathbun). The crab fauna of the Middle Paleocene, however, is more extensive, although raninids still predominate. A third member of Lyreidus, L. bispinulatus is present and Laeviranina borealis is the most northerly member of that genus and has characters in common with both European and North American species. Also taking its place among burrowing forms is Camarocarcinus quinquetuberculatus which is somewhat closer to $C$. arnesoni Holland \& Cvancara from the Cannonball Formation of North Dakota than to $C$. obtusus Jakobsen \& Collins from the Selandian of Klintebjerg, Denmark. A single fragmentary specimen of a Galathea is tentatively referred to $G$. strigifera FischerBenzon. So far as the present collection is concerned the Xanthidae is known from the Middle Paleocene by Xanthilites verrucoides which has much in common with $X$. gerti Glaessner from Argentina, while Pinnixa ( $\mathrm{Pa}$ - 
lacopinnixa) nodosa extends the known geological and geographical limits of this little known pinnotherid subgenus.

\section{Acknowledgements}

Grateful thanks are accorded to the many people who have made this work possible, both in its initial stages and those subsequent to Dr. H. Wienberg Rasmussen's death. Mr. S. Floris kindly provided facilities in the Geological Museum,
Copenhagen for J. S. H. C. to examine the extensive collection and Dr. Wienberg Rasmussen's original notes. Dr. W. K. Christensen undertook the editorial processing involved. Mr. S. F. Morris, British Museum (Natural History), London, provided access to material in his charge for comparison and offered much valuable advice. The delicate preparation of the specimens was carried out by Mr. S. L. Jakobsen, Geological Museum, Copenhagen, who also prepared the stereo-pair photographs. Direct support for this project was received by J. S. H. C. from the Geological Museum, Copenhagen and the Geological Survey of Greenland.

\section{References}

Birkelund, T. 1965: Ammonites from the Upper Cretaceous of West Greenland. Bull. Grønlands geol. Unders. 56 (also Meddr Grønland 179, 7), 192 pp.

Bromley, R. G. \& Asgaard, U. 1972: Notes on Greenland trace fossils. Rapp. Grønlands Geol. Unders. 49, 30 pp.

Christiansen, F. G., Dam, G., McIntyre, D. J., Nøhr-Hansen, H., Pedersen, G. K. \& Sønderholm, M. 1992: Renewed petroleum geological studies onshore West Greenland. Rapp. Grønlands geol. Unders. 155, 31-55.

Collins, J. [S. H.] 1961: Eocene Crabs in a London Clay nodule. Palaeontology 4, 85-86.

Collins, J. S. H. \& Morris, S. F. 1975: A new crab, Costacopluma concava, from the Upper Cretaceous of Nigeria. Palaeontology 18, 823-829.

Collins, J. S. H. \& Morris, S. F. 1976: Tertiary and Pleistocene crabs from Barbados and Trinidad. Palaeontology 19, 107131.

Collins, J. S. H. \& Smith, R. in press: Ypresian (Lower Eocene) crabs (Crustacea, Decopoda) from Belgium.

Croxton, C. A. 1976: Sampling of measured sections for palynological and other investigations between $69^{\circ}$ and $72^{\circ} \mathrm{N}$, central West Greenland. Rapp. Grønlands geol. Unders.80, 36-39.

Ehman, D. A., Sodero, D. E. \& Wise, J. C. 1976: Report on ARCO and Chevron groups 1975 West Greenland field party. Unpublished report, $76 \mathrm{pp}$.

Feldmann, R. M. 1989: Lyreidus alseanus Rathbun from the Paleogene of Washington and Oregon, U.S.A. Ann. Carnegie Mus. 58, 61-70.

Feldmann, R. M. 1991: Decapod Crustacea from the Tapui Glauconitic Sandstone (Bortonian - middle Eocene) in the Waitaki valley, South Island, New Zealand. N.Z. Jl Geol. Geophys. 34, 17-22.

Feldmann, R. M. \& Zinsmeister, W. J. 1984: New fossil crabs (Decapoda: Brachyura) from the La Meseta Formation (Eocene) of Antarctica: palaeogeographic and biogeographic implications. J. Paleont. 58, 1046-1061.

Fischer-Benson, R. v. 1866: Ueber das relative Alter des Faxekalkes und über die in demselben vorkommenden Anomuren und Brachyuren. Kiel.
Förster, R. 1971: Die Mecochiridae, eine spezializierte Familie der mesozoischen Glypheoidea (Crustacea, Decepoda). Neues Jb. Geol. Paläont. Abh. 137, 396-421.

Glaessner, M. F. 1929: Crustacea Decapoda: Fossilium Catalogus, pt. 41, 464 pp. Berlin: W. Junk.

Glaessner, M. F. 1960: The fossil decapod Crustacea of New Zealand and the evolution of the order Decapoda. New Zealand Geol. Survey, Palaeont. Bull. 31, 63 pp.

Glaessner, M. F. 1969: Decapoda: R339-R533, R626-R628. In Moore, R. C. (ed.) Treatise on invertebrate paleontology, Part R, Arthropoda 4, vol 2. Geol. Soc. America \& Univ. Kansas Press.

Goeke, G. D. 1985: Decapod Crustacea: Raninidae. Mem. Mus. Natl Hist. nat. Ser. A, Zoologie 133, 205-228.

Griffin, D. J. G. 1970: A revision of the Recent Indo - west Pacific species of the genus Lyreidus de Haan (Crustacea, Decapoda, Raninidae). Trans. Roy. Soc. N.Z. biol. Sci. 12, 89-112.

Gripp, K. 1969: Fossilien aus Norddeutschland. Meyniana 19, 79-89.

Guinot, D. \& Richer de Forges, B. 1981: Homolidae rare ou nouveaux, de l'Indo-Pacifique (Crustacea, Decapoda, Brachyura). Bull. Mus. Natn. Hist. nat. Ser. 4, 3, Sect. A, 2, 523-581.

Hansen, H. J. 1970: Danian foraminifera from Nûgssuaq, West Greenland with special reference to species occurring in Denmark. Bull Grønlands geol. Unders. 93 (also Meddr Grønland 193, 2), $132 \mathrm{pp.}$

Hansen, J. M. 1980: Stratigraphy and structure of the Paleocene in central West Greenland (onshore) and Denmark. Unpublished lic. scient. thesis, University of Copenhagen. 3 vols, $156 \mathrm{pp}$.

Henderson, G., Rosenkrantz, A. \& Schiener, E. J. 1976: Cretaceous-Tertiary sedimentary rocks of West Greenland. In Escher, A. \& Watt, W. S. (ed.) Geology of Greenland, 341-362. Copenhagen: Geological Survey of Greenland.

Henderson, G., Schiener, E. J., Risum, J. B., Croxton, C. A. \& Andersen, B. B. 1981: The West Greenland Basin. In Kerr, J. W. \& Fergusson, A. J. (ed.) Geology of the North 
Atlantic borderlands. Mem Can. Soc. Petrol. Geol. 7, 399428.

Holland, F. D. Jr. \& Cvancara, A. M. 1958: Crabs from the Cannonball Formation (Paleocene) of North Dakota. $\mathrm{J}, \mathrm{Pa}$ leont. 32, 495-505.

Holland, F. D. Jr. \& Cvancara, A. M. 1959: Correction in spelling of Camarocarcinus arnesoni Holland \& Cvancare Paleocene crab from North Dakota. J. Paleont. 33, 1 only.

Jakobsen, S. L. \& Collins, J. S. H. 1979: Decapod Crustacea from the Palaeocene of Zealand, Denmark. Proc. Geol. Ass. 90, 61-64.

Koch, B. E. 1959: Contributions to the stratigraphy of the non-marine Tertiary deposits on the south coast of the Nûgssuaq Peninsula, northwest Greenland with remarks on the fossil flora. Bull. Grønlands geol. Unders. 22 (also Meddr Gronland 162, 1), $100 \mathrm{pp.}$

Kollmann, H. A. \& Peel, J. S. 1983: Paleocene gastropods from Nûgssuaq, West Greenland. Bull. Grønlands geol. Unders. 133, 115 pp.

Kümmel, R. 1972: Seltener Crustaceenfund aus dem Danian. Der Geschiebesammler 6, 3-4, 118-122.

McNeil, F. A. 1953: Carcinological notes. 2. Rec. Aust. Mus. 23, 86-96.

Pedersen, G. K. \& Pulvertaft, T. C. R. 1992: The nonmarine Cretaceous of the West Greenland Basin, onshore West Greenland. Cretaceous Res.

Pulvertaft, T. C. R. 1987: Status review of the results of stratigraphical and sedimentological investigations in the Cretaceous-Tertiary of West Greenland and recommendations for new GGU activity in these fields. Unpubl. intern. GGU rep., $18 \mathrm{pp}$.

Pulvertaft, T. C. R. \& Chalmers, J. A. 1990: Are there Late Cretaceous unconformities in the onshore outcrops of the West Greenland Basin? Rapp. Gronlands geol. Unders. 148, $75-82$.

Rathbun, M. J. 1908: Descriptions of fossil crabs from California. Proc. U.S. Natn. Mus. 35, 341-349.

Rathbun, M. J. 1917: New species of South Dakota crabs. Proc. U.S. Natn. Mus. 52, 385-391.

Rathbun, M. J. 1926: The fossil stalk-eyed Crustacea of the Pacific slope of North America. Bull. U.S. Natn. Mus. 138, 1-155.
Rathbun, M. J. 1937: The oxystomatous and allied crabs of America. Bull. U.S. Natn. Mus. 166, 1-278.

Rice, A. L. \& Chapman, C. J. 1971: Observations on burrows and burrowing of two mud-dwelling decapod crustaceans, Nephrops norvegicus and Gonoplax rhomboides. Mar. Biol. 10, 330-342.

Roberts, H. B. 1956: Early Tertiary decapod crustaceans from the Vincentown Formation in New Jersey. Bull. Wagner Free Inst. Sci. 31, 5-12.

Roberts, H. B. 1962: The Upper Cretaceous decapod crustaceans of New Jersey and Delaware. In Richards, H. G. (ed.) The Cretaceous fossils of New Jersey. Bull. New Jersey Geol. Surv. 61, 163-191.

Rosenkrantz, A. 1967: Bjørnefælden ved Nûgssuaq og Nordboernes Eysunes i geologisk belysning. Grønland 1967, 377 384.

Rosenkrantz, A. 1970: Marine Upper Cretaceous and lowermost Tertiary deposits in West Greenland. Bull. geol. Soc. Denmark 19, 406-453.

Rosenkrantz, A. \& Pulvertaft, T. C. R. 1969: CretaceousTertiary stratigraphy and tectonics in northern West Greenland. Mem. Am. Ass. Petrol. Geol. 12, 883-898.

Segerberg, K. O. 1900: De anomura och Brachyura Decapoderna inom Scandinaviens Yngra Krita. Geol. Fören. Stockh. Förh. 22, 347-390.

Via, L. 1966: Pinnixa (Palaeopinnixa) mytilicola nuevo braquiuro fósil, en el miocene marino des Valles (Barcelona). Acta Geol. Hispan. 1, 1-4.

Whiteaves, J. F. 1903: Mesozoic fossils. 1, V. On some additional fossils from the Vancouver Cretaceous with a revised list of the species therefrom. Geol. Surv. Can., 309-403.

Woodward, H. 1898: On a new species of brachyurous Crustacea from the Chert Beds (Upper Green Sand); Baycliffe, near Maiden Bradley, Wilts. Geol. Mag. (4), 5, 302-303.

Woodward, H. 1900: Further notes on podophthalmous crustaceans from the Upper Cretaceous formation of British Columbia, etc. Geol. Mag. (4), 7, 433-435.

Wright, C. W. \& Collins, J. S. H. 1972: British Cretaceous crabs. Monogr. palaeontogr. Soc. Lond. 144 pp. (Publ. No. 533, part of Vol. 126 for 1972). 
GRØNLANDS GEOLOGISKE UNDERSØGELSE

Geological Survey of Greenland

ISSN 01053507

Øster Voldgade 10, DK-1350 Copenhagen K

AiO Print Ltd., Denmark Odense, Denmark 